\title{
Shaping climate-smart coffee landscapes
}

\section{Bachelor Thesis}

BACHELORARBEIT ZUR ERLANGUNG DES AKADEMISCHEN GRADES

"BACHELOR OF SCIENCE"

IM STUDIENGANG

ÖKOSYSTEMMANAGEMENT (B.SC.)

Vorgelegt von

\section{Paul Günter Schmidt}

aus Troisdorf

Göttingen, März 2020

Betreuer:

Dr. Christian Bunn 1,2

Lukas Flinzberger ${ }^{1}$

doi:10.53846/goediss-9078

${ }^{1}$ Department of Agricultural Economics and Rural Development (DARE), Georg-August-Universität Göttingen, Germany

${ }^{2}$ International Center for Tropical Agriculture (CIAT), Cali, Colombia 


\section{Preface}

The following thesis aims at structuring the new emerging field of climate-smart coffee landscapes and explores pathways towards implementation of climate-smart practices in coffee farming on-field while linking them to a process of integrated landscape management. The thesis consists of three parts:

\section{Basic concepts and introduction}

The first part outlines the challenges future coffee farming is exposed to due to climate change. Basic concepts of fundamental importance for this work are described and important background information on coffee farming systems and coffee market structure is given.

II. Towards climate-smart coffee landscapes

In the second part, the concept of climate-smart landscapes is theoretically applied to coffee farming dominated regions. Characteristics of climate-smart coffee landscapes are described, as well as benefits to be expected at different scales when climate-smart practices are adopted throughout the landscape. Possible constraints to implementation and challenges to farmers and institutions are discussed. Finally, a framework is developed how such climate-smart coffee landscapes can be shaped.

III. Outlook and Conclusion

The third part discusses major findings and provides an overview of further steps needed to advance towards shaping climate-smart coffee landscapes, including research themes to be investigated more closely.

Throughout the thesis, focus is laid primarily on the physical implementation of climatesmart practices on-field, their relation to the surrounding landscapes and socio-ecological interactions. The challenges of process design for integrated landscape management, especially when integrating climate-smart coffee landscapes in wider regional development strategies for sustainable development, as well as more detailed economic considerations, will have to be discussed more closely in following works. 


\section{Content}

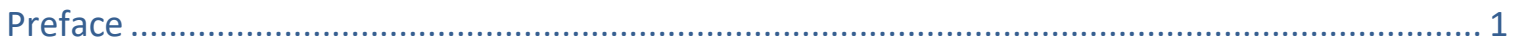

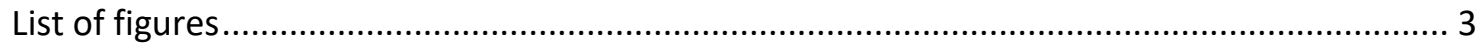

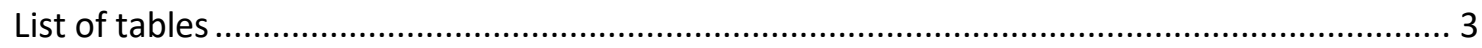

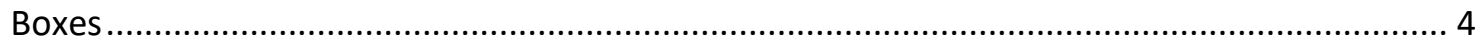

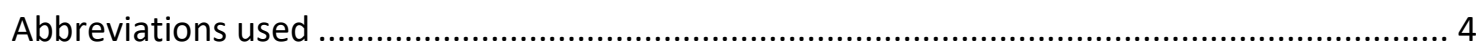

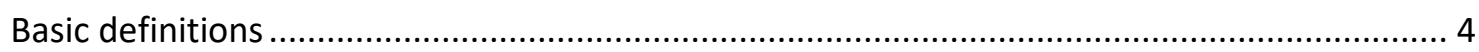

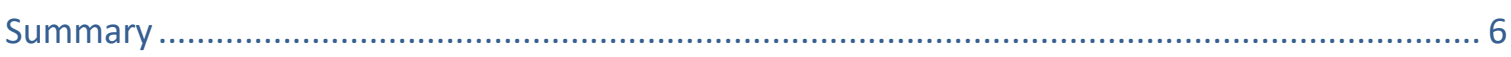

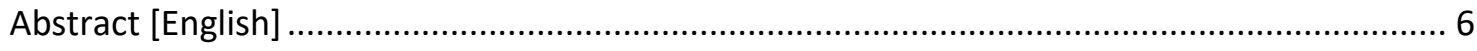

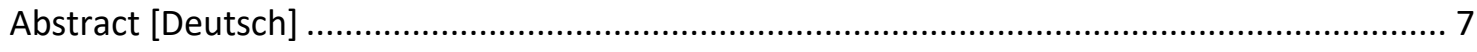

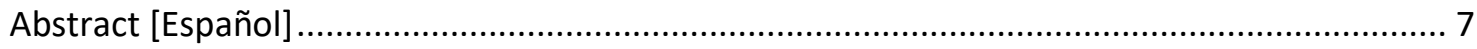

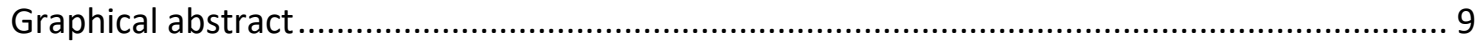

I Introduction and basic concepts ................................................................... 10

I.1 Introduction - Coffee and climate change ................................................. 10

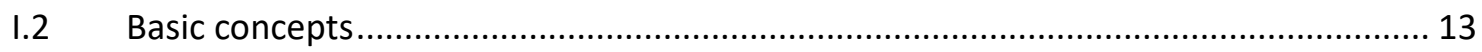

I.2.1 Landscape approach and integrated landscape management ........................... 13

I.2.2 Climate-smart agriculture and climate-smart landscapes ................................. 20

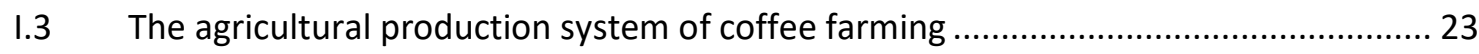

I.3.1 Coffee cultivation ................................................................................ 24

I.3.2 Market structure and socio-economic system ........................................ 26

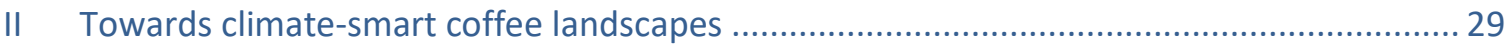

II.1 Climate-smart coffee landscapes - Core elements needed .................................. 30

II.1.1 Climate-smart practices at field and farm level ......................................... 30

II.1.2 Diversity of land uses .................................................................... 34

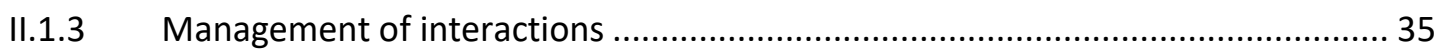

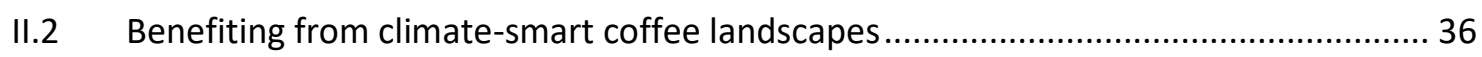

II.2.1 Field and farm level benefits of climate-smart practices.................................. 36

II.2.2 Landscape scale effects and landscape benefits ......................................... 37

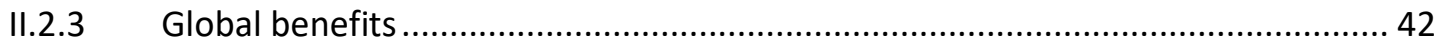

II.3 Constraints to shaping climate-smart coffee landscapes .................................... 43

II.3.1 Individual constraints - deciding on adopting climate-smart practices ............. 43

II.3.2 Institutional constraints - facilitating and organizing ................................45

II.4 Shaping climate-smart coffee landscapes - what is needed for implementation?...... 47

II.4.1 Restructuring findings - The winning Ws for implementation ..........................47 


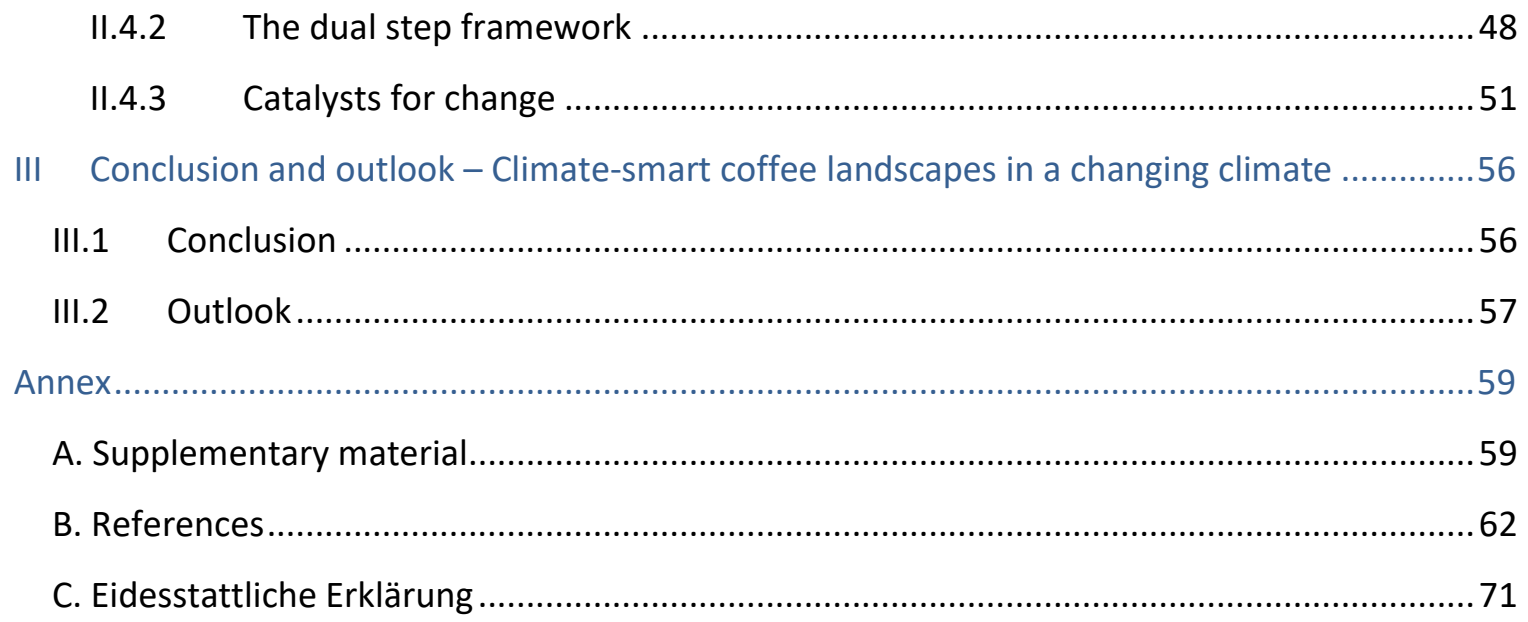

\section{List of figures}

Figure 1: Future suitability changes for coffee farming. .11

Figure 2: Proportion of ecosystem services in relation to degree of human modification. .......... 14

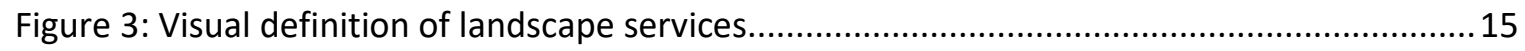

Figure 4: The five elements of integrated landscape management as proposed in GCP (2015)...17

Figure 5: Different adaptation strategies, in relation to severity of climate change impact.........20

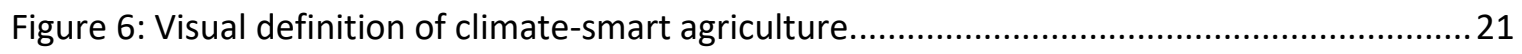

Figure 7: Overview on coffee farming systems and their environmental impacts. ....................... 25

Figure 8: Functional groupings of climate-smart practices in coffee farming................................33

Figure 9: Influence of landscape patterns of structural elements on landscape functions...........34

Figure 10: Overview of different landscape ecosystem services delivered by coffee farming...... 39

Figure 11: Possible arrangements of natural habitats and structural elements in coffee farming.

Figure 12: Overview of benefits of climate-smart practices in coffee at different scales. ............ 42

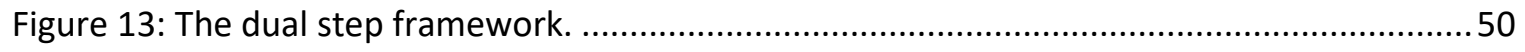

Figure 14: Visual definition and key elements of climate-smart coffee landscapes......................56

\section{List of tables}

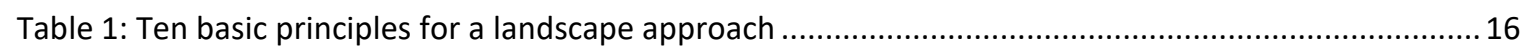

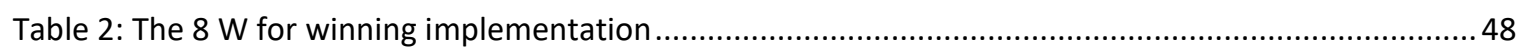




\section{Boxes}

Box 1: Case studies of ways of action of different landscape ecosystem services. 40

Box 2: Examples of possible market based incentives for climate-smart coffee landscapes 54

\section{Abbreviations used}

- CSA: Climate-smart agriculture

- CIAT: International Center for Tropical Agriculture (Centro Internacional de Agricultura Tropical)

- FAO: Food and Agricultural Organisation of the United Nations

- GHG: Greenhouse gas

- ILM: Integrated landscape management

- IPCC: Intergovernmental Panel on Climate Change

- MEA: Millennium Ecosystem Assessment

- NGO: Non-governmental organisation

\section{Basic definitions}

Basic definitions of crucial terms as understood throughout the work. In brackets sources are named on which definition draws.

\section{- Adaptation, climate change}

aims to adapt systems in a way that good livelihoods and livings can be sustained in a changing climate. (IPCC, 2015).

Throughout the thesis referred to as 'climate adaptation'.

\section{- Capacity}

is the ability to do something while possessing the resources needed, especially in terms of time and money. (FAO, 2010c).

- Climate-smart agriculture aims at improving livelihoods of the people now and in future times by adapting to climate change and considering potential for climate mitigation. (FAO, 2013).

- Climate-smart landscapes

is climate-smart agriculture integrated into a landscape wide process of integrated landscape management and aims at combining farm-scale benefits with landscape and global benefits. (Harvey et al., 2014; Scherr, Shames, \& Friedman, 2012).

\section{- Climate-smart practices} are agricultural practices that contribute to the aims of climate-smart agriculture. (Harvey et al., 2014).

- Ecosystem services are services of nature that humans profit from. (MEA, 2003).

- Knowledge is the understanding of what to do, when and how to do it. (FAO, 2011). 


\section{- Landscapes}

are spatial, socio-ecological systems that can deliver multiple services to human wellbeing. Landscapes consist of a matrix or mosaic of patches with different land uses, shaped and inhabited by different organisms (also humans) living within it and altering it. Moreover, landscapes possess their own geo-historical imprint. (FAO, 2013; Termorshuizen \& Opdam, 2009).

\section{- Landscape approach}

is a consensus driven process on a landscape scale to manage diverging interests within a landscape most efficiently, revealing synergies and minimizing trade-offs. (Sayer et al., 2013).

- Landscape elements

are structural and functional elements within a landscape. They may include trees, hedgerows, ditches, water pool and, on a larger scale, also forests, fields or meadows. (Termorshuizen \& Opdam, 2009).

\section{- Landscape services}

are the services a landscape and its elements provide to human well-being. They are ecosystem services at a landscape scale, influenced by their spatial arrangement and patterns. (Bastian, Grunewald, Syrbe, Walz, \& Wende, 2014; Termorshuizen \& Opdam, 2009).

\section{- Mitigation, climate change}

refers to stopping or reversing climate change and GHG production. Mitigation can take place by reducing GHG-footprint, sequestering carbon or preserving natural carbon stocks. (Harvey et al., 2014; IPCC, 2015).

Throughout the thesis referred to as 'climate mitigation'.

- Multifunctionality

in land use refers to the provision of multiple benefits to man, including a socioeconomic as well as an ecological dimension. (Hölting, Beckmann, Volk, \& Cord, 2019).

- Patch

is a homogenous part of land cover within a landscape, differing clearly from its surroundings, often not only visually but also functionally. (Clark, 2010).

- Resilience

is a system's or actor's capacity to recover from external shocks and to continue delivering basic functions. (IPCC, 2015).

- Vulnerability

is the susceptibility to external shocks and pressures. (IPCC, 2015). 


\section{Summary}

\section{Abstract [English]}

Coffee farming and the livelihoods of millions of smallholder farmers are threatened by climate change. Adopting climate-smart practices in coffee farming improves the livelihoods of farmers and uses synergies between climate adaptation and mitigation, while potentially providing secondary benefits to the landscape as well. Throughout this thesis the concept of climate-smart landscapes is applied to coffee regions to explore climate-smart coffee landscapes.

Aims of research are 1. characterising climate-smart coffee landscapes, 2. discussing benefits at local, landscape and global scale, 3 . identifying possible constraints, 4 . developing a framework for implementation. A review is conducted of scientific literature dealing with climate-smart landscapes and synergetic potential for adaptation and mitigation in coffee farming. Benefits are assessed based on the MEA (Millennium Ecosystem Assessment) framework for ecosystem service assessment.

It is shown that core elements of climate-smart landscapes are applicable to climatesmart coffee landscapes, including adoption of climate-smart practices on-farm, diversity of land uses within the landscape and active management of interactions. Different ways of action how climate-smart practices in coffee farming can achieve climate-smartness are identified. Diversity of land uses can already be achieved on-farm and is connected to spatial patterns. Management of interaction is important to mitigate land use conflicts and optimize the use of synergies. Additional benefits of farm based adoption of climate-smart practices at landscape and global scale are identified, including positive impacts on water flows, buffering climate extremes and conserving biodiversity. Farmers need to see the effectiveness of climate-smart practices and possess sufficient capacity and knowledge to adopt climate-smart practices. The long lead time of some practices and their diffuse impact may be challenging. Institutions need to adopt crosssectoral management to take a leading role in the process of integrated landscape management.

A dual-step framework of combined farm-scale based CSA-assessment and landscape pattern assessment is proposed. The combined analysis of specific climate change risks and farmers' individual vulnerabilities and capacities will help to develop tailored bundles of climatesmart practices for individual farmers. Considering spatial patterns in the landscape and vital landscape services in parallel, effectiveness of practices can be optimised and multi-scale winwin effects can be achieved. Governance, finance and markets can act as catalysts to facilitate change towards climate-smart coffee landscapes. When integrating the dual-step framework of combined farm-scale based CSA-assessment and landscape pattern assessment within the process of integrated landscape management, climate-smart coffee landscapes can be shaped.

This thesis provides an overview of the concept of climate-smart landscapes when applied to coffee dominated regions, identifies landscape wide benefits and proposes a framework for implementation. As an outlook, research topics emerging from the discussion of these climate-smart coffee landscapes are outlined. 


\section{Abstract [Deutsch]}

Die Auswirkungen des Klimawandels gefährden den Kaffeeanbau und damit die primäre Einkommensquelle von Millionen von Kleinbauern weltweit. Durch Klima-smarte Anbaumaßnahmen können die Lebensbedingungen von Kaffeebauern verbessert und Synergien zwischen Klimaanpassung und Klimaschutz genutzt werden. Gegebenenfalls können sie zudem landschaftsweit zusätzliche positive Auswirkungen haben. In der vorliegenden Arbeit wird das Konzept der Klima-smarten Landschaften auf Kaffeeanbau-dominierte Regionen angewendet.

Ziel der Arbeit ist es 1. Klima-smarte Kaffeelandschaften zu charakterisieren, 2. lokale, landschaftsweite und globale Auswirkungen solcher Landschaften zu diskutieren, 3. mögliche Hindernisse zu identifizieren und 4. einen Maßnahmenplan für die Gestaltung von Klimasmarten Kaffeelandschaften zu entwickeln. Es wurde wissenschaftliche Literatur zu Klimasmarten Landschaften und kombinierten Klimaanpassungs- und Klimaschutzmaßnahmen im Kaffeeanbau zusammengetragen und erörtert. Auswirkungen wurden auf Grundlage des Leitfadens der MEA (Millenium Ecosystem Assessment) zur Erfassung von Ökosystemdienstleistungen evaluiert.

Es zeigt sich, dass wesentliche Elemente von Klima-smarten Landschaften auch für Klima-smarte Kaffeelandschaften von Bedeutung sind. Klima-smarte Anbaumaßnahmen im Kaffeeanbau können auf unterschiedliche Weise zu den Zielen Klima-smarter Landwirtschaft beitragen. Eine Vielfalt an Landnutzungsformen ist bereits auf Feldebene unter anderem durch Agroforstsysteme im Kaffeeanbau möglich. Aktives Management von Interaktionen ist wichtig um Landnutzungskonflikte zu verhindern und positive Wechselwirkungen zu nutzen. Sowohl landschaftsweit, als auch global sind positive Auswirkungen von Klima-smarten Maßnahmen zu erwarten: unter anderem in Bezug auf Wassersysteme, die Milderung von Klimaextremen und den Schutz der Biodiversität. Für die Landwirte muss jedoch der Mehrwert der Maßnahmen ersichtlich werden. Außerdem müssen die Landwirte über ausreichend Wissen sowie finanzielle und materielle Ressourcen verfügen. Institutionen können eine führende Rolle im Prozess des integrierten Landschaftsmanagements einnehmen, müssen dafür aber Sektor übergreifendes Arbeiten und interdisziplinäres Denken ermöglichen.

Als Maßnahmenplan wird ein zweiphasiges Vorgehen vorgeschlagen, beidem lokale Möglichkeiten für Klima-smarte Anbaumaßnahmen erfasst, aber gleichzeitig räumliche Muster innerhalb der Landschaft beachtet werden. Eine integrierte Analyse des spezifischen Klimarisikos für Landwirte sowie individueller Schwächen und Möglichkeiten ermöglicht es, bedarfsgerecht Maßnahmenpakete von Klima-smarten Anbaumaßnahmen zu erstellen. Die parallele Analyse von Landschaftsdienstleistungen und räumlichen Mustern erlaubt es, zusätzliche Win-WinSituationen auf unterschiedlichen Ebenen zu nutzen. Regierungen, Investitionen sowie Märkte können als Katalysatoren wirken, um positiven Wandel zu befördern. Wird dieser zweiphasige Maßnahmenplan in einen landschaftsweiten Prozess des integrierten Landschaftsmanagements eingebunden, so ermöglicht er das Gestalten von Klima-smarten Kaffeelandschaften.

Diese Bachelorarbeit leistet einen grundlegenden Beitrag zur Strukturierung des neuen Forschungsfelds der Klima-smarten Kaffeelandschaften, zeigt Zusammenhänge zu Klima-smarten Landschaften im Allgemeinen auf, diskutiert positive Auswirkungen auf unterschiedlichen Skalen und entwickelt einen Maßnahmenplan zur Einführung. Darüber hinaus wird auf noch bestehenden Forschungsbedarf hingewiesen. 


\section{Abstract [Español]}

Los impactos del cambio climático amenazan los cultivos de café y el sustento económico de millones de pequeños agricultores. La adaptación de las prácticas climate-smart en los cultivos de café podría mejorar las condiciones de los agricultores, así como el uso de sinergias entre la adaptación al cambio climático y la mitigación del mismo, ofreciendo además beneficios secundarios en los paisajes. En el trabajo, el concepto de los paisajes climate-smart es aplicado a los regiones dominadas por cultivos de café.

Los objetivos de este trabajo de fin de grado son: 1. caracteriza paisajes climate-smart de café, 2. discute beneficios que estos paisajes pueden brindar a nivel local, paisajístico y global, 3. identifica posibles factores obstantes, 4. propone un marco teórico para su conformación. Se realizó una revisión de literatura científica relacionada con los paisajes climate-smart y de prácticas en los cultivos de café que implican potencial sinérgico entre adaptación al cambio climático y mitigación del mismo. La evaluación de los beneficios está basada en el marco evaluativo de los servicios de los ecosistemas de MEA (Millenium Ecosystem Assessment).

Los resultados obtenidos indican que las características esenciales de los paisajes climate-smart son aplicables a los paisajes climate-smart de café. Las prácticas climate-smart en los cultivos de café pueden tomar diferentes formas de acción para conseguir climatesmartness. En los cultivos de café ya se puede alcanzar diversidad de usos de campo al nivel de los campos únicos. Una gestión activa de interacciones es necesaria para evitar conflictos y optimizar el uso de sinergias. La adaptación de las prácticas climate-smart en los campos de café ofrece beneficios locales también como adicionales al nivel paisajístico y global, incluyendo impactos positivos en zonas fluviales, amortiguación de impactos climatológicos extremos y conservación de la biodiversidad. Para adoptar prácticas climate-smart, los agricultores necesitan conocer la efectividad de las mismas, y además poseer suficiente recursos y conocimiento. Las instituciones tienen que incluir una gestión intersectorial para poder asumir un rol de liderazgo dentro del proceso de gestión integrada de paisajes.

Se propone un marco teórico dual, que combine la evaluación de los potenciales de la agricultura climate-smart en los campos de café, junto con la evaluación de las estructuras en el paisaje. Analizar los riesgos del y vulnerabilidades al cambio climático de forma conjunta con las capacidades de los agricultores facilitará que se pueda elegir prácticas climate-smart ajustadas e individualizadas para las distintas necesidades de los agricultores. Teniendo en cuenta los patrones espaciales en el paisaje y los servicios vitales del paisaje en paralelo, se puede optimizar la eficacia de las prácticas y lograr efectos de ganancia mutua a múltiples escalas. Gobiernos, sistemas financieros y mercados económicos pueden actuar como catalizadores para facilitar la transición hacia paisajes cafeteros climate-smart. Integrando el marco teórico dual dentro del proceso de gestión integrada de campo, se pueden conformar paisajes climate-smart de café.

En síntesis, este trabajo de fin de grado, proporciona una visión integral del concepto de paisajes climate-smart cuando es aplicado a regiones dominadas por cultivos de café, identifica beneficios secundarios locales, paisajísticos y globales, y propone un marco teórico para la conformación de los paisajes climate-smart de café. Además nuevos temas de investigación son identificadas, que surgen a partir de la discusión relacionada con las mismas. 


\section{Graphical abstract}

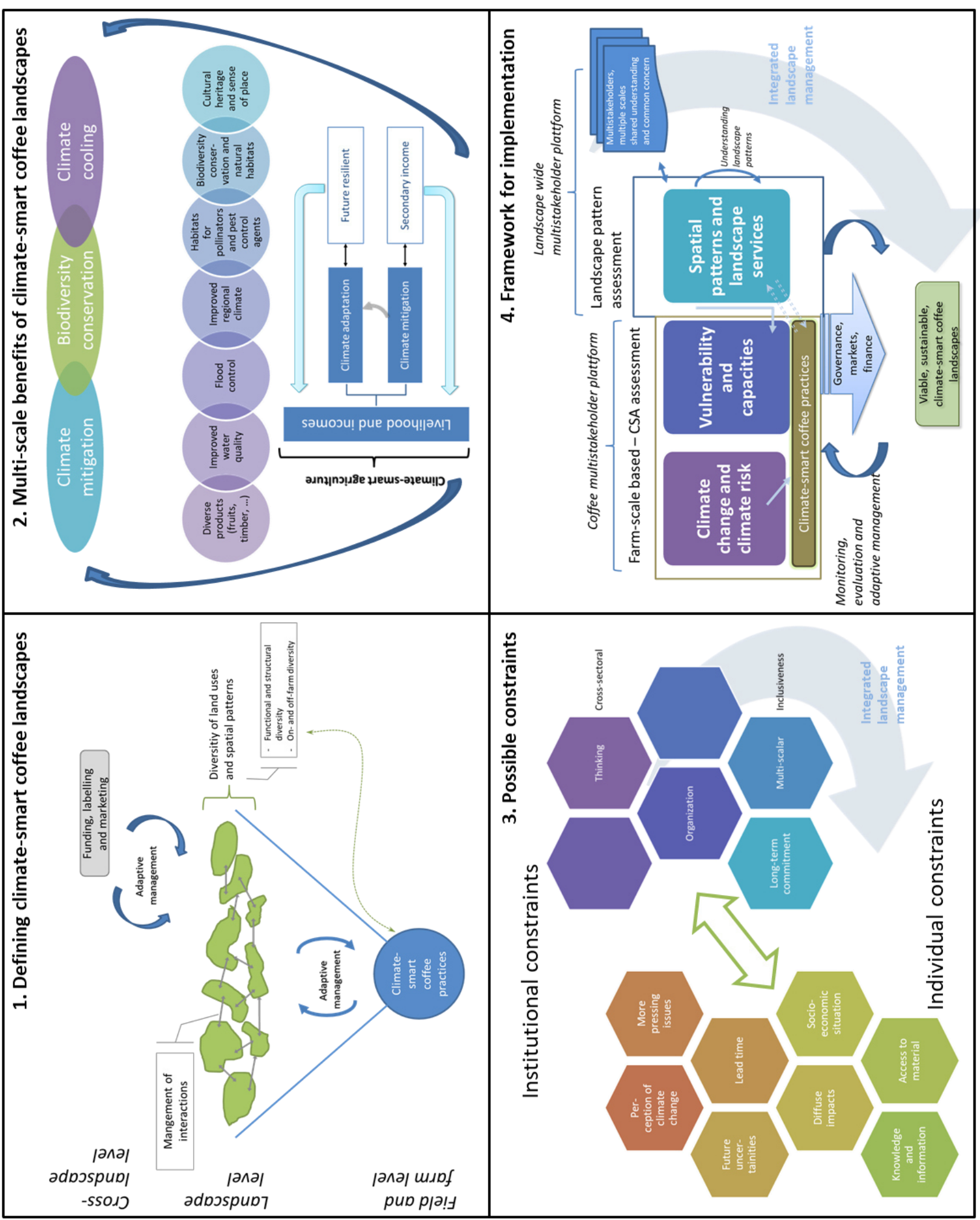




\section{Introduction and basic concepts}

This first part is divided into three blocks that provide fundamental knowledge needed for discussing climate-smart coffee landscapes and the future of coffee farming in a changing climate.

Chapter I.1 draws a bigger picture of how climate change will threaten viability of coffee farming and the livelihoods of millions of smallholder farmers. The role of coffee farming in climate change is described alongside possible climate mitigation and adaptation strategies, discussing trade-offs and synergies that may occur.

Chapter 1.2 explores new nature management strategies needed for sustainable development and how synergies between improving livelihoods, climate adaptation and climate mitigation can be achieved. The concepts of multifunctionality, as well as ecosystem and landscape services are presented. The importance of landscapes as operational scale is outlined alongside integrated landscape management as a possible strategy to manage such landscapes. Furthermore, the concept of climate-smart agriculture is presented and expanded to the concept of climate-smart landscapes, embedding climate-smart agriculture into the wider landscape context.

Chapter I.3 then takes a step back and describes the characteristics of coffee farming systems and the socio-economic system of coffee farming, so that the concept of climate-smart landscapes can be adapted explicitly to the context of coffee farming dominated landscapes later on.

\section{I.1 Introduction - Coffee and climate change}

Coffee farming and the livelihoods of millions of smallholder farmers are threatened by climate change. Farm-based climate adaptation practices hold great potential to provide valuable secondary benefits for the landscape, but can also lead to landscape trade-offs. Taking a holistic view is of great importance to avoid tradeoffs, and use synergies instead. Adaptation takes time, so action needs to be taken anticipatory.

Climate change has a strong impact on agriculture and with impacts becoming even more pronounced in the future (IPCC WG II, 2014). Global temperature rises and extreme weather conditions become more frequent (IPCC WG II, 2014). Changed patterns of precipitation lead to droughts or flooding. Climate change alters geographical distribution of crops and total area suitable for production (IPCC WG II, 2014). Pests and diseases spread more widely and their pressure on crops will increase. As a result, crop yields will decrease, while yield variability will increase (IPCC WG II, 2014; Rosenzweig \& Tubiello, 2007).

One agricultural sector affected is coffee cultivation. Impacts of climate change on coffee farming can already be experienced (Harvey et al., 2018; Jiri, Mafongoya, \& Chivenge, 2015). Though coffee production may profit from new areas suitable in higher altitudes and increased $\mathrm{CO}_{2}$ concentration causing enhanced photosynthetic rates, negative impacts will most likely be far more pronounced (Pham, Reardon-Smith, Mushtaq, \& Cockfield, 2019).

Yields depend on adequate climatic conditions during vegetative and reproductive phase, so change in global and local climates will affect coffee crop performance strongly (Pham 
et al., 2019). All vegetative phases, from growth and flowering to fruit set but also bean quality may be negatively affected (Harvey et al., 2018). Higher temperatures and greater variability of precipitation will put plants under stress, decreasing yields and coffee quality, while increasing plants' susceptibility to pests and diseases, alongside challenged pollination service (Pham et al., 2019). Of the two main coffee species farmed, Arabica (Coffea arabica) is expected to suffer strongest from higher temperatures, while Robusta (Coffea canephora) will probably be affected most by higher intra-seasonal temperature variability (Bunn, Läderach, Ovalle Rivera, \& Kirschke, 2015a).

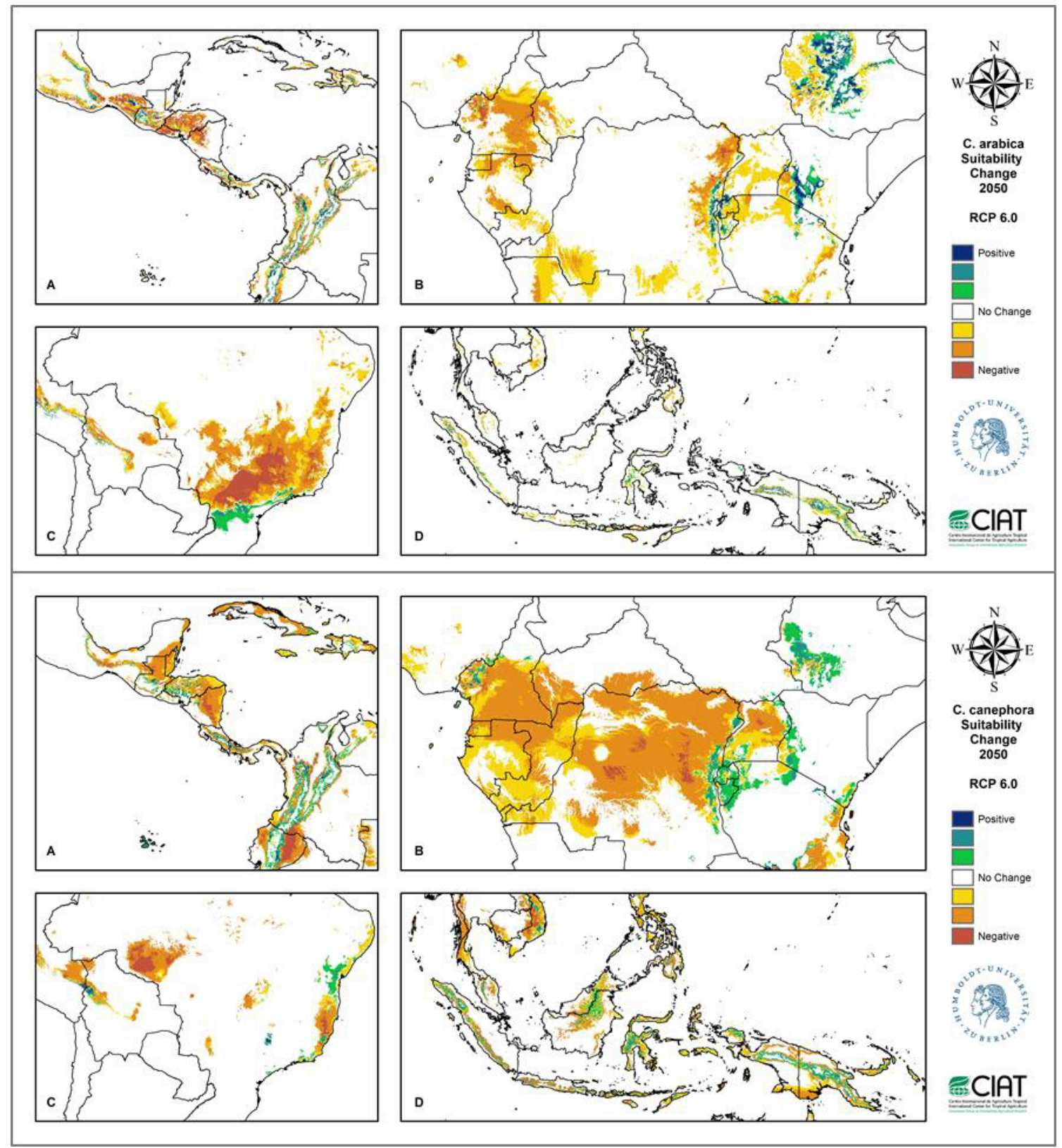

Figure 1: Future suitability changes for coffee farming. Suitability changes for Arabica (C. arabica) are shown at the top, changes for Robusta (C. canephora) at the bottom. Depicted are the most important coffee farming regions along the tropics. (Bunn, Läderach, Rivera, \& Kirschke, 2014). 
Global area suitable is estimated to decrease by up to $50 \%$ for both coffee species farmed until 2050 (Bunn et al., 2015a; Pham et al., 2019), see Figure 1 (Bunn et al., 2014). Major production regions like Brazil and South East Asia may experience even stronger decreases of area suitable, estimations reaching up to $85 \%$ (Bunn et al., 2015a). Coffee farms at low latitudes and in lower altitudes will be effected strongest (Pham et al., 2019). With coffee being a perennial plant that only starts delivering decent yields after 5-7 years from planting and stays in production for up to 20-30 years, decisions taken now will influence farming viability for the next decades (Läderach et al., 2017).

Changes in coffee suitability patterns will have severe effects on the livelihoods of millions of people. It is estimated that there are about 12.5 million coffee farmers globally (Enveritas (2018) cited in Sachs et al. (2019)), with between 100-125 million people depending on coffee farming for their livelihoods (Hivos, 2018). Most of them are smallholder farmers with only limited capacity to adapt to climate change (Harvey et al., 2018; Rahn et al., 2014).

At the same time, climate change is also driven by agriculture and coffee cultivation. Agriculture and other land uses contribute with about a quarter (23\% as average of 2007-2016) to global greenhouse gas (GHG) emissions (IPCC, 2019). Emissions are caused in various ways, as outlined in IPCC WG III (2014): Sources for GHG-emissions include inadequate soil and nutrient management, and especially livestock farming. Producing synthetic fertilizers emits $\mathrm{CO}_{2}$, while over-fertilization and bad nutrient management cause other $\mathrm{GHGs}$ like $\mathrm{N}_{2} \mathrm{O}$. Agricultural expansion can lead to deforestation and drained peatlands, destroying valuable carbon sinks and emitting further GHGs.

In coffee farming, use of fertilizer (conventional management) and soil $\mathrm{N}_{2} \mathrm{O}$-emissions (organic management) are the major sources of GHG-emissions, though numbers vary with overall management intensity (Noponen et al., 2012). Deforestation for new coffee farms, especially for sun-farmed coffee, also causes further GHG-emissions. Regarding post-harvest processing, decomposition of organic load in wastewater from depulping and fermentation is another major source of GHG-emissions if left untreated, contributing to one to two thirds of total GHG-emissions of the green coffee value chain (Rahn et al., 2014; van Rikxoort, Schroth, Läderach, \& Rodríguez-Sánchez, 2014).

Adaptation strategies to reduce impacts of climate change on coffee production exist, but often require technical knowledge or financial resources many times lacking, especially in the case of the most vulnerable smallholder farmers (Jha et al., 2011; Rahn et al., 2014; Verburg, Rahn, Verweij, van Kuijk, \& Ghazoul, 2019).

With lower altitudes becoming less and higher altitudes becoming more suitable for production, farmers may be tempted to shift to higher areas. Altitudinal migration though may induce conflicts for land, and compromise other land uses and objectives like biodiversity conservation and carbon mitigation, as often in those higher areas native forests remain (Bunn et al., 2015a; Läderach et al., 2017; Pham et al., 2019).

Many on-field climate adaptation practices can contribute to climate mitigation by directly reducing GHG-emissions though, while additionally providing further benefits (Rahn et al., 2014). Coffee farming in particular offers great opportunities to mitigate GHG-emissions already on-farm. With coffee being a perennial crop and often farmed in combination with shade trees, various elements on-farm can act as carbon sinks. Combining climate adaptation with climate mitigation could lead to win-win situations, with carbon compensation programmes 
cross-financing adaptation practices and reducing the carbon footprint of coffee production, while increasing coffee farmers' livelihoods (Läderach et al., 2017).

While private actions might increase climate resilience of individual farmers, coordinated and joint action on a landscape scale could enhance effectiveness further, using synergies while avoiding trade-offs (Biesbroek, Swart, \& van der Knaap, 2009; Rahn et al., 2014; Scherr et al., 2012; Verburg et al., 2019). Climate-smart coffee farming and climate-smart coffee landscapes try to tap this potential.

\section{I.2 Basic concepts}

Agricultural land use provides more than food and can neither functionally nor spatially be seen isolated from the landscape that surrounds it. Interactions and spatial patterns influence on-field management efficiency strongly. Landscape approaches like integrated landscape management aim for landscape multifunctionality, and try to balance different needs within the landscape. When long-term funded, they can facilitate positive landscape processes.

Climate-smart agriculture helps to achieve multiple win-win situations; livelihoods and incomes of smallholder farmers are improved, while their climate resilience is raised and a contribution to climate mitigation is made. By integrating climate-smart agriculture in a landscape wide process of integrated landscape management and thereby advancing towards climate-smart landscapes, the benefits of climate-smart agriculture are spread within the landscape, while preserving vital landscape services.

\section{I.2.1 Landscape approach and integrated landscape management}

\section{Land under pressure - call for multifunctionality}

With human population and resource consumption increasing globally, pressure on land to meet multiple demands while staying within planetary boundaries is growing (Foley et al., 2011; Steffen et al., 2015; Wu, 2013). Agricultural land occupies about $40 \%$ of global land area (World Bank, 2016) but affects about $70 \%$ of the global ice-free land surface (IPCC, 2019). The environmental and external effects of land use need to be recognized and reconciled, to secure system sustainability and safe living conditions for all the people also in future times and facilitate socio-economic developments (Steffen et al., 2015). This may be achieved through multifunctional land use (Fischer, Lindenmayer, \& Manning, 2006; O'Farrell \& Anderson, 2010).

In the field of land use, multifunctionality refers to the provision of multiple benefits to man, including a socio-economic as well as an ecological dimension (Hölting et al., 2019). The benefits provided might be marketable (commodities) or non-marketable, the latter often having positive externalities (public goods) (OECD, 2000). Multifunctional land use aims at delivering multiple ecosystem services, to maximize contributing to human well-being and achieve system sustainability. 


\section{Ecosystem services}

Ecosystem services are services of the environment that humans profit from (MEA, 2003). The concept of ecosystem services was put forward especially through the Millennium Ecosystem Assessment report in 2005 (MEA, 2005), though the assessment framework was already published 2003 (MEA, 2003). The Millennium Ecosystem Assessment distinguishes between 4 groups of ecosystem services delivered to human by nature: supporting, provisioning, regulating and cultural services.

- Supporting services are basic functions that enable the deliverance of the other services. They are of fundamental importance, but only influence man indirectly by allowing for the other services to be provided. The nutrient cycle and soil functions are examples for supporting services.

- Provisioning services include the deliverance of direct usable goods to the people, as for example food, fibre or fuelwood.

- Regulating services enable the use of certain goods or regulate system conditions in a way that human living is possible. Examples are water-filtering functions, pollination, pest control and climate regulation.

- Cultural services recognize the recreational and spiritual value of nature and influence human culture. They influence social relations and may serve as a source of inspiration.

Those ecosystem services then contribute to different dimensions of human well-being, classified into 4 categories: security, basic materials for good life, health and good social relations. Additionally freedom of choice and action is named as an overarching category.

The concept of ecosystem services offers an important new perspective, relating human well-being to the surrounding nature and nature's quality and recognizes that humans themselves are part of the ecosystem. Type and condition of the ecosystem determine quantity, quality and type of ecosystem services delivered and are related to human management, see Figure $2(\mathrm{Wu}, 2013)$. With land being a limited resource, multifunctionality and conscious planning is needed, to be able to provide multiple ecosystem services also in future times ( $\mathrm{Wu}$, 2013).

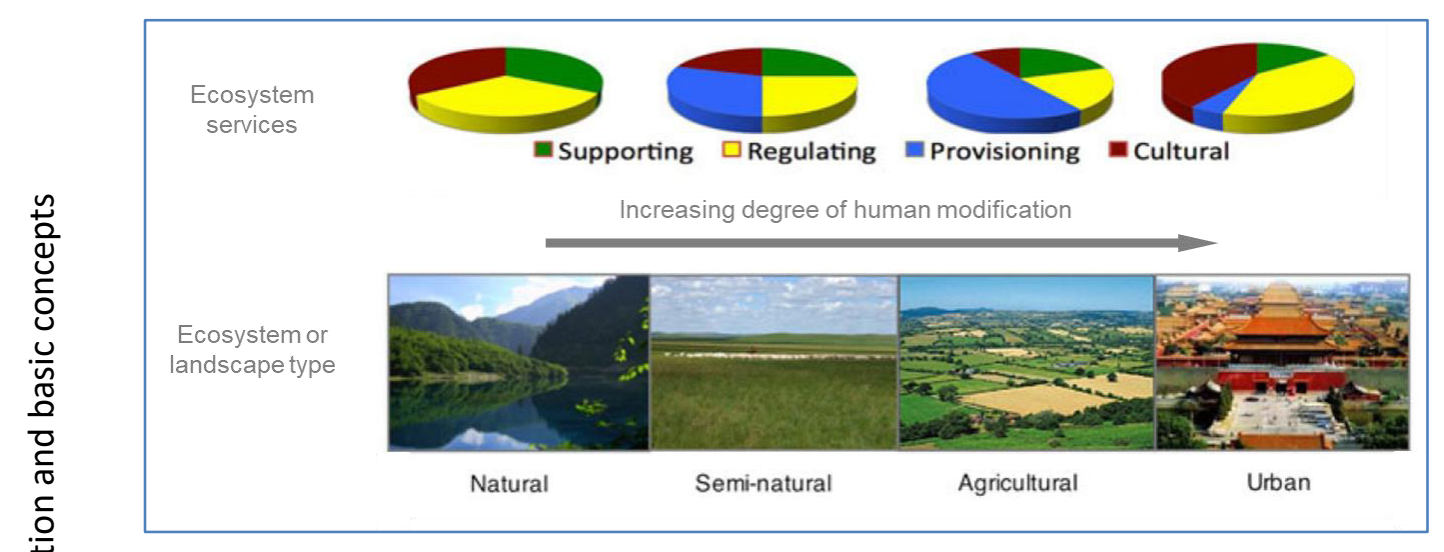

Figure 2: Proportion of ecosystem services in relation to degree of human modification. Different landscape types vary in their degree of human modification and the proportion of different ecosystem services delivered by them. It becomes notable that some land-use types are specialised by human to deliver certain types of ecosystem services. Note that volumes of pies are not proportional to total deliverance of ecosystem services. Adopted from Wu (2013) 


\section{Towards landscapes - landscape services}

Ecosystem services delivered not only depend on on-field management but are influenced by geo-climatic conditions and surrounding land uses as well (Scherr et al., 2012). When assessing ecosystem services at a larger scale, especially the spatial distribution of land uses and structural elements should be studied according to Termorshuizen and Opdam (2009). The authors put forward the term of landscape services to stress the importance of spatial patterns in deliverance of ecosystem services, see Figure 3.

Drawing on Termorshuizen and Opdam (2009) and FAO (2013), I define landscapes as spatial, socio-ecological systems that can deliver multiple service to human well-being. Those landscapes consist of a matrix or mosaic of patches with different land uses, shaped and inhabited by different organisms (also humans) living within it and altering it. Moreover, landscapes possess their own geo-historical imprint.

Landscape services can be defined as the services a landscape and its elements provide to human well-being (Bastian et al., 2014) and combine the concept of ecosystem services with spatial patterns.

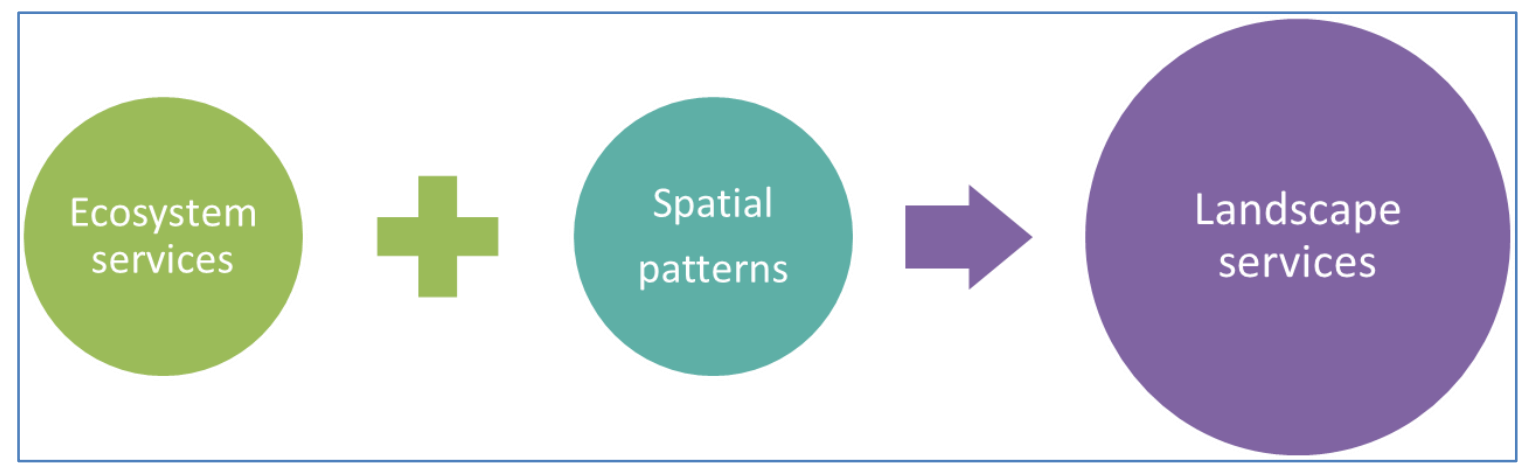

Figure 3: Visual definition of landscape services. Landscape services can be seen as joint consideration of ecosystem services and their spatial patterns across the landscape. They are ecosystem services at a landscape scale, influenced by their spatial arrangement and patterns. Based on Termorshuizen and Opdam (2009).

The actual size of landscapes can be variable. Their extent is generally defined to be sufficiently small to be managed by the people living within the landscape, producing goods and using the land, but large enough to provide vital ecosystem services to those people (FAO, 2013). Therefore, the spatial extent to be defined as 'a landscape' varies with the services to be managed (Sayer et al., 2013).

Using landscapes as operational scale seems most promising to find a balance between meeting social and environmental needs and objectives, recognizing the importance of spatial patterns, while efficiently manage their arrangement and find locally adequate solutions (Reed, van Vianen, Deakin, Barlow, \& Sunderland, 2016; Termorshuizen \& Opdam, 2009; Tscharntke, Klein, Kruess, Steffan-Dewenter, \& Thies, 2005).

What has long been done in agriculture to maximize yields - to look only at field scale, at single 'patches' (EcoAgriculture Partners, 2013) - is insufficient. Interdependence of land uses influences effectiveness of action taken. Moreover, as multiple actors within the landscape interact and compete for common resources, conflicts may arise. When focussing only on field level effects, externalities are often ignored. A broader scale is needed to optimize land use and 
to contribute to human well-being landscape wide. By taking a landscape perspective, those externalities become visible, so that they can be managed and mitigated (FAO, 2013).

\section{Landscape as an operational scale}

Climate-change will alter landscapes, no matter if landscape management is performed or not (Freeman, O. E., 2015). However actively managing change can help to reduce negative impacts and offers an anticipatory pathway, using maximum synergistic potential (Freeman, $\mathrm{O}$. E., 2015).

When using landscapes as an operational scale, a landscape approach is taken (FAO, 2013). Landscape approaches try to manage diverging interests and objectives within landscapes, balancing social, economic and environmental needs (Sayer et al., 2013). In general they share 10 characteristics defined by Sayer et al. (2013), based on a review of landscapes approaches in scientific literature, see Table 1.

Table 1: Ten basic principles for a landscape approach Based on: Sayer et al. (2013)

\begin{tabular}{|lll|}
\hline General set-up: & i. & Multiple scale \\
& ii. & Multiple stakeholders \\
& iii. & Common concern entry point \\
\hline Process design: & iv. & Negotiated and transparent change logic \\
& v. & Clarification of rights and responsibilities \\
& vi. & Participatory and user-friendly monitoring \\
& vii. & Continual learning and adaptive management \\
\hline Objectives: & viii. Multifunctionality \\
& ix. & Resilience \\
& x. & Strengthened stakeholder capacity \\
\hline
\end{tabular}

Sayer et al. (2013) outline those 10 basic principles as following:

Regarding the general set-up (i.-iii.) multiple stakeholders should be included, building up a common concern entry point, while recognizing multiple scales. Delivering one solution that fits all will often be impossible. Instead, negotiations have to take place to define which objectives should be prioritized and where trade-offs are accepted.

The process design (iv.-vii.) should be integrative and transparent, clarifying individual rights and responsibilities and encouraging actors to participate in the process. As effects are often entangled and systems are complex, unforeseen obstacles may occur. Adaptive management is needed, including continuous evaluation and learning loops integrating observations and knowledge of all stakeholders involved or being affected to mitigate misdevelopments.

The objectives to be achieved (viii.-x.) generally include aiming at multifunctionality within the landscape and helping to build up resilience contributing strengthening stakeholders' capacities but will primarily relate to the common concern entry point of the stakeholders.

A landscape approach cannot be seen as a linear process, possessing a clear end point (Sayer et al., 2013). Rather it consists of iterative loops that need to be repeated over and over 
again, advancing step by step (Sayer et al., 2013). Like Wu (2013) stated on sustainability: to be "more of a process than a state" (p. 1020). To stress this procedural aspect, and also to recognize ongoing developments within landscapes, I will use the term 'to shape' rather than 'to create' throughout this work when referring to the process of advancing towards climate-smart (coffee) landscapes.

\section{Integrated landscape management}

A great confusion remains on how such a landscape approach can actually be operationalized, given the individual common concern entry points each situation might have (EcoAgriculture Partners, 2013; Reed et al., 2016). Integrated landscape management is named as the most common concept in literature, but in most cases it remains unclear what is exactly meant with it (EcoAgriculture Partners, 2013; Reed et al., 2016).

Throughout this work, I will use the strategy for integrated landscape management proposed by the Global Canopy Programme (GCP, 2015) as a guiding framework for integrated landscape management, as it is the most widely explained. The framework consists of 5 central elements, namely (1) a multi-stakeholder platform, (2) shared understanding, (3) collaborative planning, (4) effective implementation and (5) monitoring, which are designed as steps of a process, see Figure 4. Additionally catalysts that facilitate change are outlined and grouped as (a) governance, (b) finance and (c) markets.

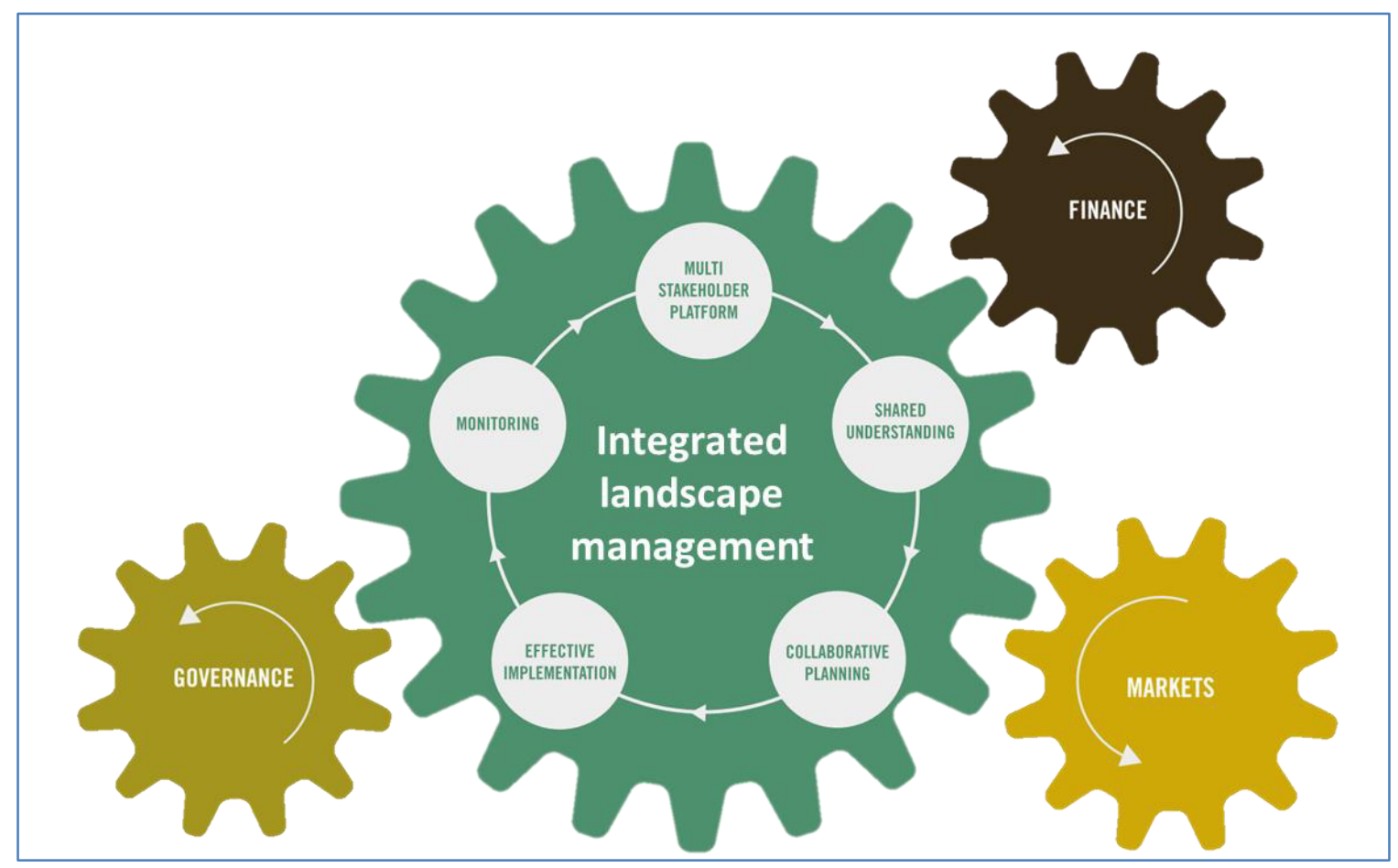

Figure 4: The five elements of integrated landscape management as proposed in GCP (2015). The three catalysts governance, finance and markets can facilitate and accelerate positive change. Adopted from GCP (2015). 
GCP (2015) outline these elements as following:

(1) Establishing a multi-stakeholder platform

To start, a multi-stakeholder platform has to be established. In most of the cases, the platform will be initiated by two or more actors that share common concerns. Examples could be NGOs joining forces with the local government to reduce deforestation rates within a region or producer cooperatives combining with local initiatives to raise environmental production standards. From there on, different actors are to be integrated. The actors integrated might share the common concern, are potentially affected by interventions planned and/or are relevant for achieving change. Actors to be integrated not necessary all need to be from within the region but can also include national o international companies having a stake within the region or influencing it.

\section{(2) Develop a shared understanding}

The next element is to develop a shared understanding among stakeholders. Consequences of following a business-as-usual pathway and the concerns arising from this possible future need to be understood. Landscapes services that are crucial for stakeholders' viability are to be identified jointly to be able to secure them. Spatial patterns needed are to be considered, especially as they influence strongly delivering of landscape services. Also, the institutional and legal contexts need to be made clear to identify possible challenges early.

\section{(3) Plan collaboratively}

With stakeholders connected through the multi-stakeholder platform and the threats of business-as-usual trajectories understood, pathways towards landscape sustainability are to be developed using collaborative planning. Different scenarios of change can be used to compare landscape impacts of trajectories and agree on optimum configuration. To be able to evaluate progress later on and develop transparent change logic, clear goals and objectives for change are to be set, ideally SMART (specific, measurable, achievable, relevant and time-bound).

\section{(4) Effective Implementation}

Moving on from planning to on ground action, effective implementation is to be aimed at. Further cooperation needed is to be considered, integrating research institutions but also possible funders. Communication and process management structures are to be established, for example through regular process meetings, to keep up momentum and continue stakeholders' integration.

\section{(5) Establish monitoring and adaptive management procedures}

Change will take time and unforeseen problems might arise, so monitoring is needed to be able to adapt management. Also funders like NGOs, development banks or impact investors often require a proof of effectiveness for accountability. Therefore, and to measure change, clear indicators are to be developed, based on the objectives defined beforehand. Indicators should encompass different dimensions (social, ecologic, economic) and scales (field, farm, landscape) within the landscape and ideally build up on data easily assessable or already existent. 
Change can be facilitated, improved and accelerated through external catalysts, grouped by GCP (2015) as governance, finance and markets:

\section{(a) Governance}

Governance and governmental action shape the 'playing rules' within a region. It is upon governmental action to enforce and monitor compliance with regulations and sanction violation. Law making influences what can be done or not. Clarifying and securing tenure rights is key to facilitate long-term and future orientated planning. Governance should include elements of public participation and integration of local knowledge in decision making, instead of imposing a pure top-down regime. By organizing cross-sectoral governance, different land uses and objectives may be considered jointly, with synergies and trade-offs becoming visible. Governmental programmes may support integrated landscape management through supportive programmes, knowledge transfer or assessment of data.

\section{(b) Finance}

Change will be costly but is necessary to secure incomes in future times, with cost of inaction prone to be significantly higher, especially in times of climate change (see also Stern (2006)). Finance may include direct investment for change but also restructuring of financial schemes, for example by uniting climate adaptation and mitigation programmes to enable synergies. Taxes introduced by the government can shape action and set positive or negative incentives. Carbon taxes for example can act as incentives for companies to compensate $\mathrm{CO}_{2}$ emissions or elsewise reduce their carbon footprint directly.

\section{(c) Markets}

Markets influence action. Whether or not products are marketable or not can determine their valuation. While marketable products (commodities) are valued high, public goods and ecosystem services like clean water or biodiversity are under threat of over- or misuse. Creating markets for public goods and ecosystem services can provide monetary incentives to preserve these goods. New economic sectors may arise that have certain ecosystem services as their principal production good and thus will be highly motivated to preserve them to sustain their incomes. Ecotourism for example values rich biodiversity and undisturbed nature and converts it into marketable goods. Also certification and their standards offer opportunities to include nonmarketable goods into prices.

In most cases it will be impossible to create the 'perfect' landscape that meets all demands placed up on it, and trade-offs will occur. However, it can and should be aimed at finding the best possible solution for the local context, fulfilling the needs considered the most important by the people within the landscape, while integrating also objectives from greater (global and national) and smaller (household, farmer) scales. The strategy of integrated landscape management can help to achieve this.

Landscapes are a relevant scale for planning and negotiating multiple land uses and multiple resource claims within a region, while recognizing externalities and assuring system sustainability. Advancing towards system sustainability and resilient landscapes needs participative, iterative and integrative long-term processes that encompass multiple stakeholders and multiple scales to achieve multiple objectives (Reed et al., 2016). The 
landscape approach and integrated landscape management help to balance those competing claims and offer a framework for integrating processes to shape and manage those systems.

\section{I.2.2 Climate-smart agriculture and climate-smart landscapes}

Climate change is a global problem of growing importance, especially threatening the livelihoods of smallholder farmers (Morton, 2007). With agriculture contributing to about a quarter of global GHG-emissions (IPCC WG III, 2014), solutions are sought after to combine adaptation to climate change with climate mitigation (Locatelli, Pavageau, Pramova, \& Di Gregorio, 2015; Rosenzweig \& Tubiello, 2007). The concept of climate-smart agriculture (CSA) is one such solution, bringing together climate mitigation and adaptation to improve people's livelihoods. It was developed by the Food and Agriculture Organisation (FAO) in 2010 (FAO, 2010a) and since then has been promoted strongly by international organisations like the FAO and the World Bank (FAO, 2013; World Bank, 2011).

\section{Climate adaptation and climate mitigation}

Climate adaptation aims at adapt systems in a way that good livelihoods and livings can be sustained in a changing climate, whereas climate mitigation refers to stopping or reversing climate change and GHG production (IPCC, 2015).

Climate adaptation strategies differ with local impact of climate change. Stafford Smith et al. (2011) differentiate between incremental and transformative adaptation, depending on severity of adaptation need. Additionally Vermeulen et al. (2013) refer to systemic adaptation as an intermediate step, as specified for coffee farming in Verburg et al. (2019). Where incremental adaptation is needed, current objectives can still be reached with minor system changes (Stafford Smith et al., 2011). Systemic change already requires more severe action and is of higher complexity (Vermeulen et al., 2013), whereas where transformative change is needed, fundamental change in objectives of production might be required (Stafford Smith et al., 2011), see Figure 6.

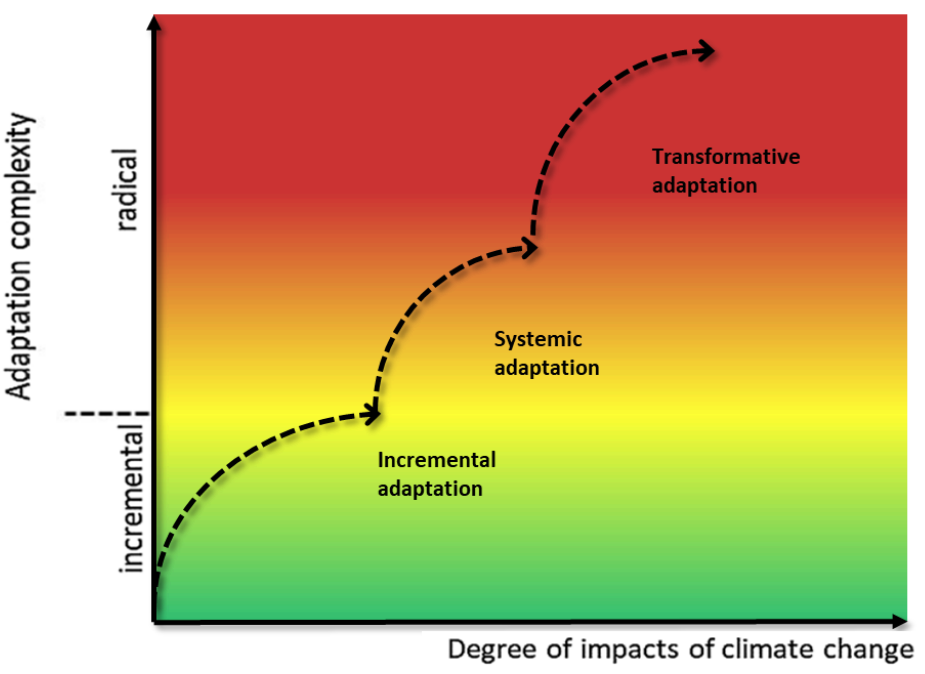

Figure 5: Different adaptation strategies, in relation to severity of climate change impact. Adopted from Verburg et al. (2019). 
Climate mitigation can be achieved by avoiding GHG-emissions, sequestering carbon or preserving natural carbon sinks. Avoiding GHG-emissions can be accomplished at any step in the lifecycle of agricultural production (Harvey et al., 2014), may it be pre- (production of fertilizers), on- ( $\mathrm{N}_{2} \mathrm{O}$ emissions from over fertilization) or post-farm (processing). Carbon can be sequestered above or below ground, for example in soil organic matter or in woody biomass, increasing onfield carbon stocks (Harvey et al., 2014). Natural carbon sinks can be preserved by avoiding deforestation or agricultural degradation of for example native forests or peatlands (Harvey et al., 2014).

\section{Climate-smart agriculture}

Climate-smart agriculture meets the challenge of adapting to climate change, securing or improving livelihoods, while recognizing the potential of the agricultural sector for climate mitigation (FAO, 2013), see Figure 6. Sustainable improvement of productivity and livelihoods is always prioritized, but as in times of climate change climate adaptation is needed to sustain those livelihoods, adaptation becomes a crucial part of the strategy (FAO, 2013). For farmers, aspects of mitigation are especially attractive when compensated externally, for example when carbon compensation payments are made, whereas institutions like governments or companies may acknowledge synergies to lower their carbon footprints while assuring for farmers' livelihoods (FAO, 2013).

In climate-smart agriculture, the main strategy to improve livelihoods is sustainably increasing productivity and thereby incomes. Nevertheless, incomes may also be increased through reduced management costs or diversified economic opportunities, either from secondary crops farmed or carbon compensation programmes.

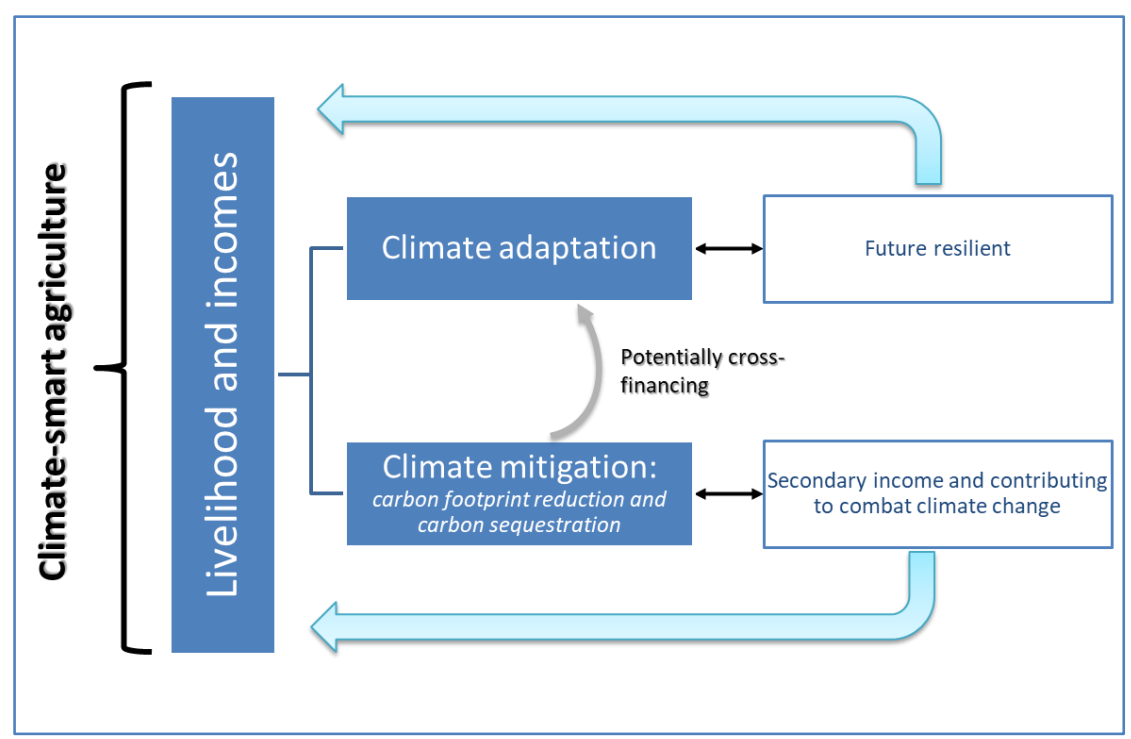

Figure 6: Visual definition of climate-smart agriculture. Definition according to the basic objectives of climate-smart agriculture: aiming to improve livelihoods through either increased resilience when adaptation to climate change takes place, directly increasing incomes by increased productivity or climate mitigation delivering secondary incomes and cross-financing adaptation costs. Based on FAO (2013).

A broad range of possible climate-smart practices exist, integrating practices stemming from concepts like conservation agriculture, ecological agriculture, agroforestry or sustainable 
intensification of cop productivity (Harvey et al., 2014). They are combined to achieve the objectives of secured livelihoods, climate adaptation and climate mitigation in ways that synergies are achieved and trade-offs avoided (Scherr et al., 2012). The practices to be adopted always need to be matched to the specific context, especially considering current and future environmental and climate conditions (FAO, 2013).

Addressing improvement of livelihoods jointly with climate adaptation and mitigation uses synergies to enhance resource use and effectiveness of actions taken. Likewise it is tried to avoid trade-offs that may occur when mitigation, adaptation or improved livelihoods are aimed at separately (FAO, 2013). Climate-smart agriculture links the fundamental idea of improved agriculture as leverage for food security, better livelihoods and economic development to its ambiguous role as driver and victim of climate change.

\section{Combining climate-smart agriculture and integrated landscape management to advance towards climate-smart landscapes}

Most of the practices to be adopted under the approach of climate-smart agriculture take place on a field or farm level (Scherr et al., 2012). However, agriculture is part of a landscape, interacting with surrounding land uses, being influenced in positive but also negative ways while competing for common resources (Minang et al., 2015). The concept of climatesmart landscapes draws on the principles of multifunctional landscapes and integrated landscape management to combine them with climate-smart agriculture, enhancing effectiveness and aiming to achieve landscape wide benefits (Harvey et al., 2014; Scherr et al., 2012).

Field and farm level based actions are interconnected with surrounding land uses as is productivity (Minang et al., 2015; Scherr et al., 2012). Farm level actions may affect neighbouring areas positively or negatively, for example crop diversification enhancing biodiversity and providing habitats for pollinators or biological control agents (Tscharntke et al., 2012), while adversely excessive use of fertilizers reduces water quality with negative effects on downstream areas (Harvey et al., 2014; Zhang, Ricketts, Kremen, Carney, \& Swinton, 2007).

When implementing climate-smart agriculture practices, considering integrated landscape management can enhance effectiveness, helps to identify landscape benefits early and allows for optimized landscape configuration (Harvey et al., 2014).

Scherr et al. (2012) describe and outline 3 key features of climate-smart landscapes: (1) the adoption of climate-smart practices by the farmers, (2) a diversity of land uses within the landscape and (3) a management of interactions at the landscape scale:

(1) Adoption of climate-smart practices at field and farm level

Climate-smart practices should be adopted throughout the landscape to achieve climate adaptation and climate mitigation. Those practices need to be adapted to the respective land use, may it be forestry, agriculture or livestock farming and grassland management (Scherr et al., 2012). 


\section{(2) Diversity of land uses}

Different land-use types should be present throughout the landscape, contributing to a heterogenic land-use mosaic of land uses with diverging functional traits and diverging land covers. Different crop varieties but also natural habitats should be included. Diversity reduces risks of yet uncertain future climatic conditions and contributes to risk spreading, maybe even serving as food and feed reserve. Thereby, landscapes will become more resilient and better adapted to climate change. Also, livelihoods may be sustained or even improved, as dependence on performance of single crops is reduced.

\section{(3) Management of interactions}

Interactions between the different land users and actors within the landscape should be managed, drawing especially on the multi-stakeholder platform in the process of integrated landscape management. Conflicts can be mitigated or even avoided and effectiveness of climatesmart agriculture practices is enhanced, for example when effects of scale are achieved or positive interactions are used, with benefits delivered on-field but also throughout the landscape. Furthermore, by recognizing spatial relationships and the role of landscape elements, central landscape functions can be preserved.

Climate-smart agriculture aims at improving livelihoods of farmers, drawing on climate adaptation potential and recognizing opportunities for climate mitigation, thereby achieving multiple synergies. Climate-smart landscapes integrate climate-smart agriculture and its practices on-field, while drawing on the process of integrated landscape management to enhance effectiveness, use synergies with secondary objectives and mitigate conflicts within the entire landscape.

\section{I.3 The agricultural production system of coffee farming}

Coffee is a woody perennial that can be farmed as an understory plant in agroforestry systems. High structural and functional diversity can be achieved already on-farm and the system offers great potential for building up important carbon stocks on-field.

As an international cash crop, coffee farming is an important source of income for millions of farmers globally, but international roasters shape the market. With climate change challenging future viability of coffee production in terms of quantity as well as quality, actors within the value chain may be intrinsically motivated to support climate adaptation on coffee farms.

Adapting the concept of climate-smart landscapes to coffee dominated regions requires understanding of coffee farming system and socio-economic conditions. This chapter gives a brief overview on the agricultural system of coffee farming and the socio-economic system of coffee. 


\section{I.3.1 Coffee cultivation}

The coffee plant is a woody perennial crop that naturally grows as understory plant in tropical rainforests. Globally, coffee is mainly cultivated in latitudes between $22^{\circ} \mathrm{N}$ and $26^{\circ} \mathrm{S}$ (Descroix \& Snoeck, 2009), the so called 'coffee-belt' (Grabs \& Ponte, 2019). Of global coffee production, nearly all coffee is produced from two species: Arabica (Coffea arabica) and Robusta (Coffea canephora). Arabica holds a greater share with about $60 \%$ of global production whereas the remaining $40 \%$ account to Robusta (USDA, 2019).

\section{Bioclimatic conditions}

Descroix and Snoeck (2009) describe the characteristics of each species as follows:

Arabica plants are more climate sensitive but their coffee beans are valued higher for their superior taste. They are farmed mainly in altitudes between 1,200 to 2,000 meters above sea level (m.a.s.l.) ideally with temperatures between 18 and $22{ }^{\circ} \mathrm{C}$ all year. Optimum relative air humidity is around $60 \%$ and annual rainfall should be well above $1000 \mathrm{~mm}$, preferably between 1400-2000 mm.

Robusta coffee beans have a less complex taste, so they are valued less, even though their caffeine content is higher. The plant withstands higher temperatures, with optimum temperatures, between $22-28^{\circ} \mathrm{C}$. Robusta is farmed in lower altitudes (250-1,500 m.a.s.l.) and hotter climates (Jaramillo et al., 2011). However, it also needs higher values for relative humidity (optimum 70-75\%) and higher levels of precipitation, minimum $1200 \mathrm{~mm}$ but ideally between 2000-2500 mm.

For both species rainfall patterns should include some month with little to no precipitation to induce flowering (Descroix \& Snoeck, 2009). Harvest takes place during dry season, which should ideally have a length of 2-3 month to facilitate optimum conditions for harvest and processing (Descroix \& Snoeck, 2009). Excessive temperatures and moisture should be avoided, as well as situations of drought (Wintgens \& Descroix, 2009).

When cultivated, plants are generally pruned to shrub size to facilitate harvest and increase productivity (Wintgens \& Descroix, 2009). Soils should be deep, permeable, slightly acid and porous, with high water retention capacity. Preferably, the soil should be well structured with an high organic compound (Descroix \& Snoeck, 2009). Strong winds can cause harm to the plant and should be avoided. Where unavoidable, windbreaks need to be installed (Descroix \& Snoeck, 2009).

\section{Pest and diseases}

Major diseases and pests in coffee are the coffee leaf rust (Hemileia vastatrix), a fungus mainly present in hot climates and lower elevations, profiting of high relative humidity (Muller, Berry, Avelino, \& Bieysse, 2009; Verburg et al., 2019) and the coffee berry borer (Hypothenemus hamperi), an insect formerly found in lower elevations but spreading to higher elevations as climates change (Jaramillo et al., 2011). Other diseases include nematodes and, in higher elevations, the coffee berry disease (Wintgens, 2009). Coffee rust and coffee berry borer both benefit from climate change (Verburg et al., 2019). The spores of coffee rust spread by wind, so large open plantations favour distribution (Avelino, Romero-Gurdián, Cruz-Cuellar, \& Declerck, 2012). Generally the plant is most susceptible to diseases when under stress (Krishnan, 2017). 


\section{Influence of shade}

Traditionally coffee is farmed under shading conditions but in the last decade an increasing share has been converted to plain sun cultivation (Jha et al., 2014). Requirements for shade differ according to elevation and temperature (Jha et al., 2014). Shade can have positive impacts on coffee yields and bean quality, but temperature regulation needs to be balanced with photosynthetic rate (Jha et al., 2014). Shade trees may buffer extreme temperatures and lift water from deeper soil layers, to upper ones, where it becomes available to coffee plants (Verburg et al., 2019). Also, when nitrogen fixing trees are used they provide nitrogen to coffee plants and improve plant performance. However, shade level and species of shade trees should be well-chosen as they might also compete with coffee for light nutrients and water (Pham et al., 2019; Verburg et al., 2019).

Yields can be maximized with shade levels of about 35\% (Jha et al., 2014; Perfecto, Vandermeer, Mas, \& Pinto, 2005). For lower values, plants may suffer from stress due to high temperatures whereas, higher values (above $50 \%$ ) may decrease yields due to lack of sun and/or competition for water (Perfecto et al., 2005; Soto-Pinto, Perfecto, Castillo-Hernandez, \& Caballero-Nieto, 2000). Coffee beans produced in shade are normally of higher quality, as they mature more slowly and their aroma has more time to develop (Jha et al., 2014). However, optimum shade levels for both, quality and yield differ strongly with biophysical factors (Jha et al., 2014), local cloud cover and shade tree species (Verburg et al., 2019).

\section{Coffee production systems}

Coffee production systems can be differentiated in traditional polycultures, commercial polycultures, shaded monocultures and unshaded monocultures, with different degrees of production intensity and environmental impacts increasing in this order (Jha et al., 2011), see Figure 7.

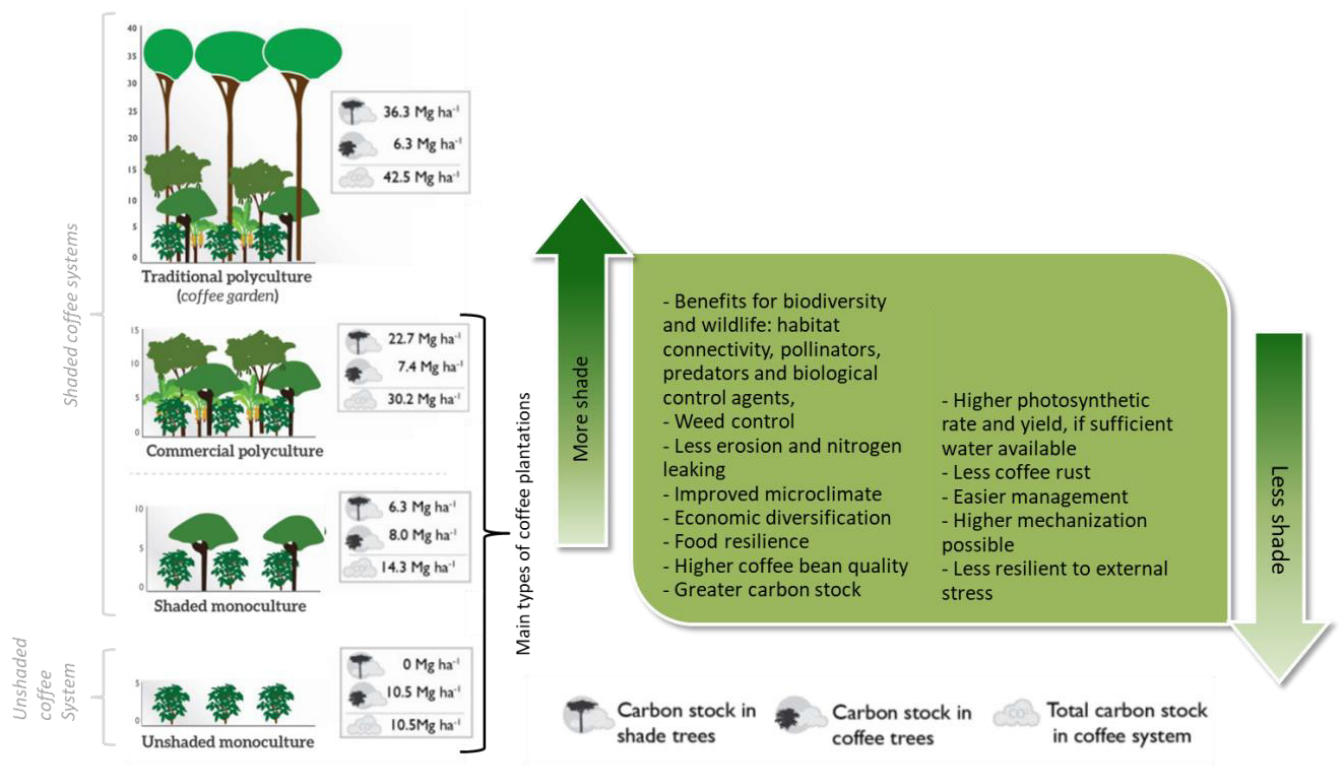

Figure 7: Overview on coffee farming systems and their environmental impacts. Different coffee farming systems and the environmental and economic impact of higher or lower levels of shade alongside their carbon sequestration potential. Adopted from CIAT (2017), van Rikxoort et al. (2014) and Jha et al. (2011). 
The different production systems are described by Moguel and Toledo (1999) as follows: Traditional polycultures consist of agroforestry systems with multiple strata and various species of native overstory trees. The overstory trees provide shade to coffee and may provide additional incomes from fruits, fuelwood or timber. Those systems often resemble traditional rainforest systems but can be found rarely as coffee yields are low. Commercial polycultures include different shade trees, not necessary all native to the region, which all contribute to production, either through fruit production or fuelwood. Shaded monocultures only include one species of shade tree. Those trees are developed strategically alongside the understory coffee plant by regular pruning. Often exotic trees are used to maximize productivity. Unshaded monocultures, often also referred to as sun-grown coffee, are characterized by high production intensity and are often combined with irrigation to avoid situations of stress for the plant. Where relief is adequately plain, as in many regions of Vietnam and Brazil, systems of sun-grown coffee include high degrees of mechanization. Under irrigation or when farmed in areas with sufficient rainfall and adequate temperatures, highest yields are achieved (Schnabel et al., 2018).

Harvest is labour intensive, with labour cost contributing to the total production cost with about $40-45 \%$ for small to medium sized plantations and about $20 \%$ in larger, more mechanized plantations (Rodriguez \& Vasquez, 2009).

Depending on the productive system, environmental and socio-economic impacts vary. Systems with higher degrees of shade can store more carbon (van Rikxoort et al., 2014), are more climate-resilient (Pham et al., 2019), can deliver more diverse ecosystem services and contribute more strongly to nature and biodiversity conservation (Tscharntke et al., 2011).

\section{I.3.2 Market structure and socio-economic system}

\section{Socio-economic importance}

Coffee is a major source of income for millions of people around the world, many of them smallholder farmers (Jha et al., 2011; Pham et al., 2019). Coffee farming provides jobs and contributes to poverty alleviation and the economies of the countries where it is farmed (Jha et al., 2011; Pham et al., 2019).

Worldwide, there are about 12.5 million coffee farmers (Enveritas (2018), cited in Sachs et al. (2019)). Including their families, an estimated number of about 60-120 million people's livelihood depend on coffee farming, though estimations are variable. ${ }^{1}$ The great majority of producers are smallholder farmers, farming under 10 ha, in Mesoamerica often under 2 ha or even less (Jha et al., 2011). In contrast, farms in producer countries like Indonesia and Peru also

\footnotetext{
${ }^{1}$ Exact numbers on coffee farmers are surprisingly hard to find. Jha et al. 2011 estimate for 4.3 million smallholder coffee farmers, which would add up to about 6 million coffee farmers in total when calculating with a $70 \%$ share of smallholders in production cited by Pham (2019). In contrast, Waller, Bigger, \& Hillocks (2007) report for 25-30 million coffee farmers globally, a number which was cited widely throughout literature for many years (e.g. Jayakumar, Rajavel, Surendran, Gopinath, \& Ramamoorthy, 2017; Hivos, 2018; Chemura, Kutywayo, Chidoko, \& Mahoya, 2016). However, the most recent empirical assessment by Enveritas (2018) accounted for 12.5 million farmers, which seems to be the most up-todate number.

Calculating total number of people depending on coffee for their livelihoods proofs even more challenging. Estimations range from 62.5 million (Sachs et al. 2019) to 100-125 million (TCl, 2016; Hivos, 2018; Fairtrade Foundation, 2020), the latter number cited more widely.
} 
include larger farms with 10-100 ha, whereas In large production countries like Brazil and also Guatemala, individual farms often expand even further, partly over more than 100 ha each (Jha et al., 2011).

\section{Coffee market structure}

The coffee value chain basically consists of farmers, domestic traders, exporters and international traders, roasters and retailers (Ponte, 2002). Grabs and Ponte (2019) describe coffee market structure as follows: Farmers often organize in cooperatives to gain more market power but roasters are the dominant players with strong power regarding bargaining with retailers and multinational traders and largest value share stays with roasters. However, growing demand for speciality coffee offers the opportunity to increase share of income generated earlier in the value chain. Coffee is produced nearly entirely as an export orientated cash-crop for the international market, being strongly interrelated with and influenced by global trade mechanisms. Most coffee is traded as fungible product with little to no differentiation in quality or origin, though by improved traceability, production region, quality and variety, as well as sustainability issues become of increasing importance on the market. This holds especially true for higher quality Arabica and, to a lesser extent for Robusta as well. Prices are highly volatile, posing trouble to smaller producers and hindering market entry.

\section{Coffee production in times of change}

Supply and demand in the coffee sector can be described as inelastic, as coffee plants have a lead time of minimum two years from planting until first yields, often longer, with highest yields achieved not earlier than seven or eight years from planting (Rodriguez \& Vasquez, 2009), but plants remain productive for up to 20-30 years (Wintgens \& Descroix, 2009).

Decisions taken by farmers and their business partners today will influence the productions viability for the next decades and may take years to show first effect, especially when considering productivity of entire agroforestry systems, with overstory trees having an even greater time-lag between planting and production (Läderach et al., 2017). Therefore, as reaction to changed prices on a short-term only crop management intensity is adjusted, including resource use and labour input (Läderach et al., 2017; Ponte, 2002).

Climate change will severely affect coffee viability (Pham et al., 2019) and traders and roasters might be challenged to meet future demands in quantity and quality (Läderach et al., 2011). Areas formerly known for their distinctive taste and rewarded through a price premium may struggle to justify price premiums, as changing climates alter coffee profile (Läderach et al., 2011), similar to the discourse on denomination of origin in changing climates in the wine sector described by Mosedale et al. (2016).

Production costs may rise as adaptation can be costly (ITC, 2010), artificial irrigation for example is resource intensive to implement. Conflicts may arise over water use or altitudinal migration causing deforestation. This may also have adverse effects on coffee marketing, as environmental impacts like water footprint and in the case of tropical products especially deforestation free supply chains become of increasing importance to consumers (Lambin et al., 2018).

However, the strong connection of coffee producers to markets in the global north may also be an advantage for the producer's livelihoods. Up to a certain degree, traders and roasters 
further up the value chain have an actual interest in maintaining viability and quality of coffee produced in designated regions, to avoid building up new supply chains and to assure the viability of their supply chain. Certification marks like UTZ/Rainforest Alliance with large market share become increasingly aware of carbon mitigation potential of coffee farming (UTZ, 2020). Niche markets for low carbon do exist already (see for example NAMA Café (2020)) and may cross-finance adaptation when climate-smart practices are implemented (Rahn et al., 2014). This can be of great help when heading towards the creation of climate-smart landscapes and financing adaptation measures for farmers living in precarious socio-economic conditions (Rahn et al., 2014).

\section{Looking back - Climate change, coffee and integrated landscape management}

Climate change threatens viability of future coffee production. Less land will be suitable for production, climate variability and uncertainties of future climatic developments challenge production and planning processes. The livelihoods of millions of coffee farmers and their families are threatened globally, as well as the economies of their respective countries. Adaptation to climate change is needed.

Considering jointly climate adaptation and climate mitigation to improve livelihoods is core to the concept of climate-smart agriculture. Implementing measures to improve agricultural and landscape multifunctionality can be done most efficiently by taking a landscape approach. Taking a landscape approach, interactions need to be managed, synergies can be revealed and trade-offs minimized, heading towards climate-smart landscapes.

Coffee farming holds potential to mitigate climate change. The characteristics of the coffee plant being a woody perennial that can be farmed as an understory plant in agroforestry system make it well suited to combine climate adaptation and mitigation already on-field and contribute to further objectives additionally.

In part II the concept of climate-smart landscapes is applied to coffee dominated regions to identify characteristics of climate-smart coffee landscape, identify benefits and possible constraints, to be finally able to develop a framework for shaping climate-smart coffee landscapes. 


\section{Towards climate-smart coffee landscapes}

\section{Looking forward - Heading towards climate-smart coffee landscapes}

To explore the concept of climate-smart coffee landscape, this part will try to answer the central research questions of the thesis.

Chapter II.1 starts with defining what climate-smart landscapes are when applied to a coffee dominated context and proposes a structure for addressing different functional traits of climate-smart practices to be applied in coffee farms.

Chapter II.2 explores why climate-smart coffee landscapes might be desirable and what benefits can be expected at different scales when climate-smart practices are adopted in coffee farms within the landscape, as well as how different actors may profit from climate-smart coffee landscapes. Also the interdependence of coffee farms with surrounding land uses is analysed, considering especially the influence of spatial patterns.

Chapter II.3 focusses on challenges that may arise when trying to shape climate-smart landscapes. Understanding what influences farmers' decision on implementing climate-smart practices is crucial to be able to overcome barriers. Also, institutional constraints regarding support for farmers' transition towards climate-smart coffee farming and climate-smart coffee landscapes are studied.

Based on the findings on central elements of climate-smart coffee landscapes, their benefits at different scales and possible constraints, chapter II.4 draws up a framework for action. Analytical steps to tailor climate-smart practices to local and individual specifics are outlined and methods to identify possible synergetic connections related to landscape services and their respective spatial patterns are described. Moreover, additional perquisites for an effective change process are discussed. 


\section{II.1 Climate-smart coffee landscapes - Core elements needed}

The core elements of climate-smart coffee landscapes draw from those of climatesmart landscapes: adoption of climate-smart practices on-farm, a diversity of land uses within the landscape and active landscape management that mitigates conflicts and facilitates positive interactions. Climate-smart practices in coffee farming can take different ways of action to achieve climate-smartness: improving local climate, soil characteristics, nutrient or water management as well as system functioning in general or preserving natural habitats, also off-farm. Diversity includes structural and functional diversity, which can already be achieved on-farm and is connected to spatial patterns. Management of interactions links the dominant land use, coffee farming, to other land uses within the landscape and contributes to achieving synergies and minimizing trade-offs.

The following characterisation of climate-smart coffee landscapes builds up on the definition of climate-smart landscapes from Scherr et al. (2012), but was adapted to the coffee context.

\section{II.1.1 Climate-smart practices at field and farm level}

Climate-smart coffee landscapes include a multitude of different land uses within them, though coffee production is the predominant one. Within the landscape, climate-smart practices are to be integrated at field and farm level. In coffee farming, climate-smart practices can contribute to the overall goals of climate-smart agriculture in different ways. Different climatesmart practices can possess differently pronounced functional groups, often even the same time. To clarify the different ways of action how climate-smart practices in coffee farming contribute to climate-smartness, functional groups are defined. Groups should help to apply climate-smart practices on field, choosing practices most adequate for local needs

Functional groups were identified based on a search of scientific and gray literature. Farm level based adaptation and mitigation practices have been compiled, that are framed under, or are applicable to, the concept of climate-smart agriculture. Ideally, sources explicitly referred to practices for coffee farming. Where reference was made only to climate-smart agriculture in general, results were refined for practices relevant to coffee farming or coffee dominated farming systems. Main consideration for relevance was whether practices are applicable to perennial woody crops, and whether they are applicable in climate and soil conditions where coffee is farmed. Moreover, compatibility with general coffee farming practices was looked after. A list of applicable practices can be found in the supplementary material. This collection was then used to define functional groups, according to different ways of action.

Climate-smart practices or practices that contribute to climate adaptation or mitigation were listed in various sources. Scherr et al. (2012) and FAO (2013) list climate-smart practices for agriculture in general, as well as Harvey et al. (2014) who offer an overview on practices that contribute to climate adaptation and mitigation and possible synergistic potential. For coffee cultivation in particular, possible climate adaptation measures are listed in c\&c (2015) and by Pham et al. (2019) and Verburg et al. (2019). Combined adaptation and mitigation practices, are 
listed in Rahn et al. (2014) for the region of Nicaragua, whereas in CIAT (2017) an extensive list of specific climate-smart practices for coffee farming in Honduras is provided.

For climate-smart practices in coffee farming, 7 functional groups can be identified contributing to the overarching goals of livelihoods, climate adaptation and climate mitigation and often offering additional benefits, see also p. 33 Figure 8.
1. Soil characteristics
2. Water management
3. Crop and genetic diversity
4. Climate buffer and adjustment
5. Nutrient management
6. Structural elements and natural habitats
7. System functioning

They contribute to improved livelihoods, adaptation and/or mitigation through the following way of actions:

\section{(1) Soil characteristics}

Soil is vital for coffee crop performance as plants extract water and nutrients from it, with the top $30 \mathrm{~cm}$ being of special importance for coffee plants (Wintgens \& Descroix, 2009). Any loss of soil should be avoided. Soil organic matter improves system resilience and contributes to important nutrient and hydrological cycles and poses important adaptation and mitigation benefits (Harvey et al., 2014; Scherr et al., 2012). Measures like application of biochar or mulching contribute to building up soil organic matter and help to improve soil structure (CIAT, 2017). Furthermore mulching keeps the soil covered, contributing to reduced soil erosion (CIAT, 2017) and can also reduce soil water loss.

\section{(2) Water management}

Improving water management and minimizing water erosion lead to better water availability for the plant and reduced nutrient loss (Harvey et al., 2014; Verburg et al., 2019). Improving irrigation efficiency and water use in general is an important element in developing sound climate adaptation strategies, maintaining viability of coffee farming also in regions with reduced climatic suitability (Pham et al., 2019). When wastewater treatment is introduced in wet processing of coffee beans, GHG-emissions can be avoided as well (Rahn et al., 2014).

\section{(3) Crop and genetic diversity}

Higher genetic diversity and use of more adequate breeds lowers production risks by increasing resilience to environmental shocks and maximizing crop suitability under the given climate (Pham et al., 2019; Scherr et al., 2012). More diverse systems generally show higher resilience (Tscharntke et al., 2012) and better adapted crops may be less susceptible to new pests and diseases entering the regions when climate changes (Verburg et al., 2019). If woody crops are introduced for diversification, on-field biomass increases, meaning a higher on-field carbon stock, and contributing to climate mitigation.

(4) Climate buffer and adjustment

Elements that buffer extreme climatic conditions avoid situations of stress, which would 
compromise crop performance and would increase susceptibility of coffee plants to pests and diseases (Pham et al., 2019). Shade trees for example can reduce air temperatures and lower wind speeds (Pham et al., 2019). Moreover, they can serve as additional source of income and reduce dependency on coffee (Harvey et al., 2014). However, shade level and species of shade trees should be adjusted to local conditions as they might also compete with coffee for light, nutrients and water when chosen wrong (Pham et al., 2019; Verburg et al., 2019).

\section{(5) Nutrient management}

Nutrient supply is crucial for crop performance. Sustaining an adequate level of nutrients maximizes yields while lowering susceptibility to pests and diseases. Moreover, when using green manure or similar organic fertilizers, production costs for the farmer may be lowered (Scherr et al., 2012). Also, using organic instead of mineral fertilizers avoids production related GHG-emissions. Nitrogen fixing shade trees may improve crop performance while lowering need for fertilizers.

(6) Structural elements and natural habitats

Protection and restoration of structural elements and natural habitats on- and off farm can secure deliverance of important ecosystem services like pest control, pollination or improved climate to the coffee production (Verburg et al., 2019). They also act as important carbon sinks van Rikxoort et al. (2014). In general, increasing productivity and climate resilience on-field helps to take pressure from natural habitats still under protection, likewise preserving ecosystem functions delivered by them (FAO, 2013).

\section{(7) System functioning}

Improved system functioning mainly refers to better crop performance or lowered management costs. Requiring less external input such as herbicides or synthetic fertilizers avoids GHGemissions and lowers management costs, while improved crop performance increases productivity (Verburg et al., 2019). Examples for practices are integrated pest management with lowered costs for pesticides, and pruning which enhances crop performance and lowers susceptibility to pests and diseases, while offering fuelwood additionally (c\&c, 2015).

Some climate-smart practices may be applicable to multiple functional groups. Shade trees for example act as climate buffer, can improve water management by drawing water from deeper soil layers, but when being a nitrogen fixing species, at the same time contribute to nutrient management (Verburg et al., 2019).

Scale matters when studying the benefits of different climate-smart practices (Öborn et al., 2015). Practices on-farm have strong implications for the surrounding landscape, while at the same time the efficiency of practices adopted will be influenced strongly by the surrounding landscape mosaic. Likewise, measures may imply optimum scales. From the groups named above, water management and climate buffer and climate adjustment are enhanced strongly in their effectiveness when applied at a landscape scale (Harvey et al., 2014; Scherr et al., 2012). The deliverance of vital ecosystem services of natural habitats may partly be achieved through climate-buffer and adjustment elements, however with conservation of natural habitats and structural elements on a larger scale, super additive effects may be achieved (Freeman, O. E., 2015; Verburg et al., 2019). 


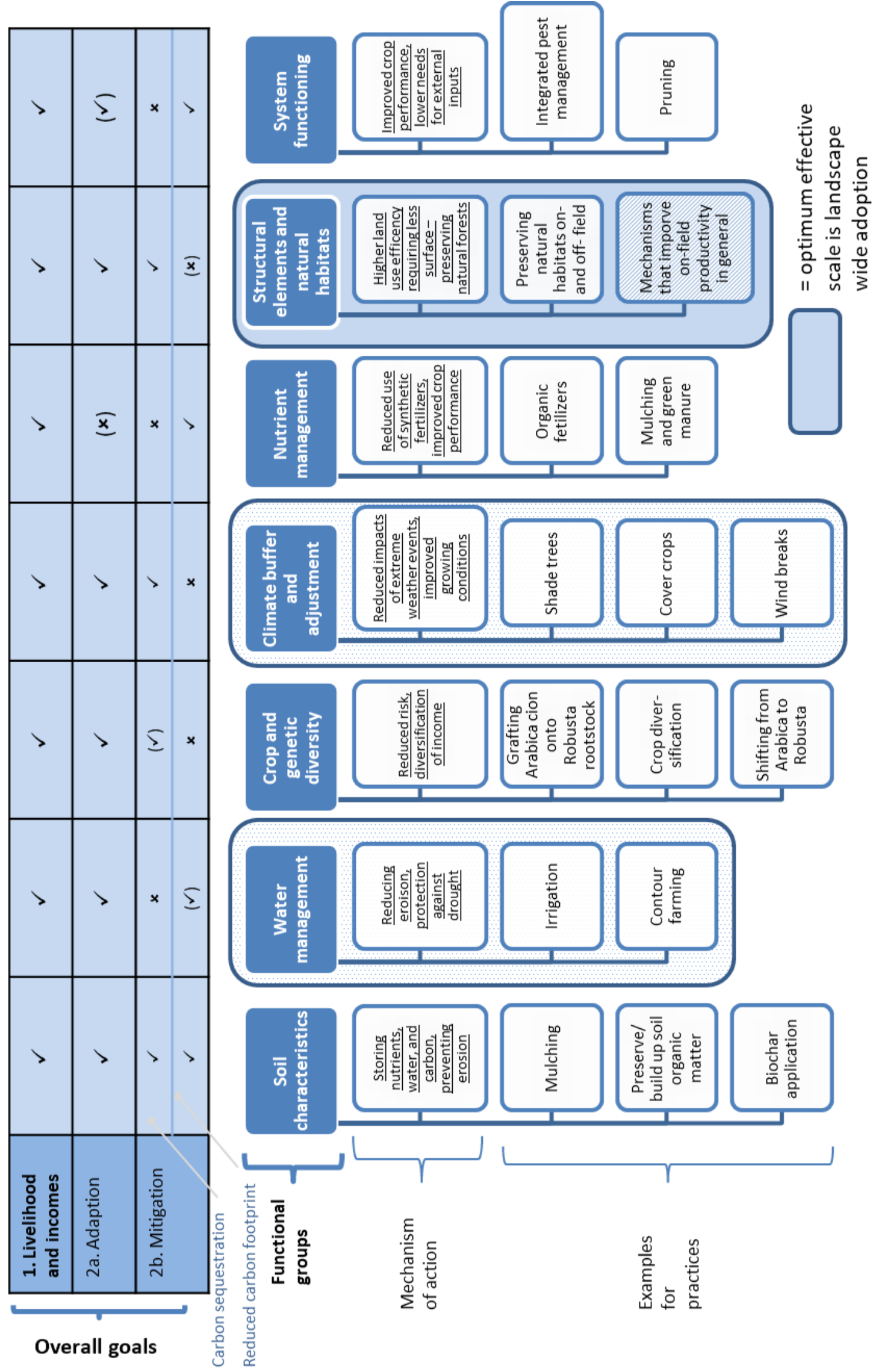

Figure 8: Functional groupings of climate-smart practices in coffee farming.

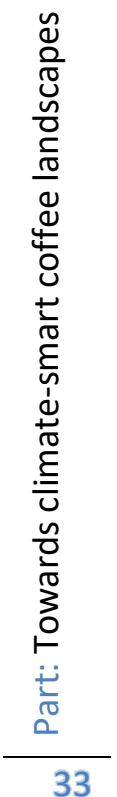




\section{III.1.2 Diversity of land uses}

In coffee farming, diversified production on farm can be seen as additional source of income and risk insurance for times where coffee prices or coffee yields are low (Rahn et al., 2014). On a landscape scale, diversity of different land uses holds benefits for the coffee farmers themselves but also for other land users within the landscape. Heterogeneity of land uses across the landscape for example may decrease speed of disease spread and can increase the landscape's resilience to extreme weather events (Verburg et al., 2019).

In coffee cultivation the main crop, coffee, can be cultivated as an understory plant. Hence, unlike in annual cropping systems, coffee systems can maintain already a considerably high structural and functional diversity on farm, also vertically, while still producing well (Tscharntke et al., 2011). In climate-smart coffee landscapes diversity therefore cannot only be achieved between different fields but also directly on-field.

Spatial patterns determine functionality and resilience of landscapes (Opdam, Luque, Nassauer, Verburg, \& Wu, 2018; Tscharntke et al., 2012). Considering consciously the distribution of different land-use types within the landscape and conserving strategically important elements can contribute to achieving further objectives (Lovell \& Johnston, 2009). Landscape ecology shows how different spatial patterns can influence functionality, depending on the combination and position of nature elements and the distribution of different land uses (Goldman, Thompson, \& Daily, 2007; Termorshuizen \& Opdam, 2009; Torquebiau, 2015), as can be seen in Figure 9.

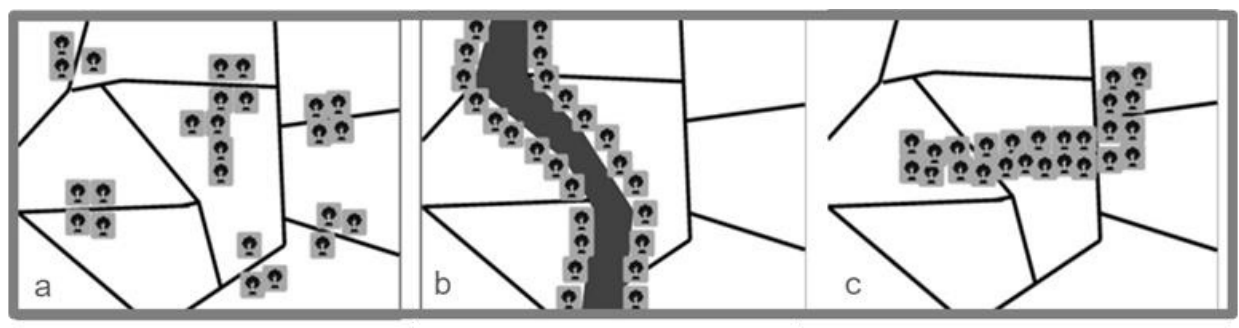

a. Structural elements increase landscape permeability and promote spill-over of organisms to adjacent lands, delivering ecosystem services of pollination or natural pest control.

b. Here they serve as flood mitigation buffer and run-off filter, enhancing water quality while also contributing to habitat connectivity alongside the river.

c. Clustered structural elements offer enhanced landscape connectivity and a less disturbed habitat, of special importance to disturbance sensitive organisms.

Figure 9: Influence of landscape patterns of structural elements on landscape functions. Adopted from Goldman et al. (2007). 


\section{III.1.3 Management of interactions}

Management of interactions tries to resolve conflicts between different land users and stakeholders within the landscape, maximizing synergies for efficient land use and minimizing trade-offs (Scherr et al., 2012). Active management contributes to enhancing field and landscape level benefits of climate-smart practices, securing vital ecosystem functions, maximizing effectiveness of mitigation efforts and mitigating land-use conflicts (Scherr et al., 2012), but may also maximize effectiveness of adaptation likewise and offer access to financial resources for example through landscape certification initiatives.

Field level benefits in climate-smart coffee landscapes may be enhanced when management of interactions focusses on spatial patterns. Field level management may have a more direct influence on productivity but surrounding land uses are also of great importance. Coffee plantations, being only embedded in other coffee plantations for example favours spread of coffee pests and diseases (Verburg et al., 2019). When vast open areas surround the plantation, wind can cause damage to crops (Verburg et al., 2019).

Vital ecosystem functions may be preserved when interdependence of coffee farming and other land uses on landscape services is considered. Nature elements within the landscape, for example can deliver vital landscape services like pest control and pollination but are also influenced by the surrounding land uses (Verburg et al., 2019). Agreeing and identifying vital landscape services helps to secure those landscape services especially as adaptation strategies like irrigation and relocation of farms to higher altitudes can put pressure on natural habitats (Pham et al., 2019) and without guided planning, crucial landscape services might be lost.

Effectiveness of mitigation and adaptation may be maximized as various practices show effects of scale and possess an optimum effective scale within the landscape, like for example improvement of regional climate (Ellison et al., 2017) or preserving natural habitats (Tscharntke et al., 2012). For efficient landscape wide climate adaptation, landscape-scale coordination is needed. Here, also synergies to achieving multiple objectives can be identified and trade-offs avoided, ultimately improving livelihoods and incomes of all the people within the landscape.

Management of interactions can mitigate land-use conflicts. Different land-users possess their individual set of objectives, interests and resource claims, eventually leading to conflicts if communication fails. In coffee, such a conflict may be even more pronounced as coffee is nearly entirely export orientated, leading to imbalance between public goods within the landscape and private profits for individual farmers. Environmental disservices of coffee farming or pressure on common pool resources like native forests or water may cause conflicts when left unsettled. Identifying, recognizing and negotiating interests between local land use and international exportation is important to mitigate conflicts and improve the livelihoods of all the people within the landscape.

Working jointly towards planning a climate-smart coffee landscapes facilitate access to funding and investment as part of climate mitigation payments or from development cooperation. Especially in the case of coffee as a global export crop, climate-smartness of the landscape might also serve as selling argument. A distinctive label for example may profit form the increased awareness of consumers from the global north for the climate impact of their actions and set free financial resources for adaptation within the region. 
Climate-smart coffee landscapes are largely equivalent to climate-smart landscapes but have coffee as dominant land use. Practices to be adopted can have different ways of action to contribute to overall goals of climate-smart agriculture and can deliver additional benefits. In coffee farming adopting those practices offers the opportunity to achieve diversity already onfarm and may deliver multiple landscape services additionally. Some climate adaptation strategies in coffee farming may compromise common pool resources, so management of interaction is needed. With coffee being linked to international markets, a landscape-scale climate-smartness label may attract financial resources to preserve crucial landscape services and finance climate adaptation within the landscape.

\section{II.2 Benefiting from climate-smart coffee landscapes}

Adoption of climate-smart practices in coffee farming and climate-smart coffee landscapes can provide multiple ecosystem and landscape services with benefits reaching far beyond the farm scale. Not only coffee farmers, other land users as well and potentially all people within the landscape can benefit from the landscape services provided. Spatial arrangements of measure taken within the landscape will determine efficiency and effectiveness. On a global scale, climate-smart coffee landscapes provide benefits through climate mitigation, conservation of biodiversity and climate cooling.

\section{II.2.1 Field and farm level benefits of climate-smart practices}

When adopting climate-smart practices, farmers can profit in multiple ways. Climatesmart practices may increase productivity, for example when growing conditions are optimized through the use of shade trees. Management costs are lowered for example with mulching suppressing weeds, decreasing necessity of manual weed control or use of herbicides, while offering additional fertilization to the plants. Likewise, nitrogen fixing plants decrease quantities of fertilizer needed. Parallel, with adaptation taking place, climate resilience increases. Additionally, ecosystem services preserved for the landscape may have beneficial effects fo the farmer as well.

Farmers may profit from new sources of income: secondary crops, introduced as climate buffer and adjustment elements or for enhanced crop diversity can be used for selfsupply, fodder for animals or be sold at local or international markets. Prunings can be used as fuelwood. Protection of ecosystem services may be rewarded through national or international payments for ecosystem services and carbon mitigation through carbon compensation payments. A label as 'climate-smart coffee landscape' may achieve higher selling prices at the market, raising farmers' incomes further and cross-financing adaptation measures to increase climate resilience further. 


\section{II.2.2 Landscape scale effects and landscape benefits}

Landscape benefits of climate-smart coffee landscapes are caused by adoption of climate-smart practices on-field, secondary benefits can be optimized when active management of interaction takes place. In the following, first landscape ecosystem services provided through adoption of climate-smart practices in coffee farming will be analysed, alongside their connection to human well-being. Then the effect of different spatial patterns of structural elements in coffee farming and their influence on landscape services will be discussed more in detail. Discussing ecosystem services at a landscape scale in general, it will be referred to landscape ecosystem services, while when including also considerations of spatial patterns the term landscape services will be used.

To assess landscape benefits of adoption of climate-smart practices in coffee farming systems, the Millennium Ecosystem Assessment (MEA) framework (MEA, 2003) was used as a guideline, but adapted to the special context of i) assessing an agricultural system (coffee farming) and ii) assessing especially the benefits from implementing climate-smart practices on field. The functional groups defined in Chapter II.1.1 were used to identify different landscape ecosystem services delivered. Landscape ecosystem services then were assigned to the three 3 groups of ecosystem services, provisioning, regulating and cultural services, defined in (MEA, 2003). As supporting services only have an indirect effect on humans, they were excluded from the analysis. Examples for beneficial impacts on other land uses within the landscape, here other agricultural land use and tourism, were identified. Landscape ecosystem services were related to the well-being of the people within the landscape according to the categories for human wellbeing defined in MEA (2003).

To study landscape services and their spatial patterns instead of just landscape ecosystem services, firstly literature was compiled that made reference to spatial arrangements influencing ecosystem services of coffee farming. Then basic coffee landscape structures and their corresponding landscape services were analysed.

\section{Landscape ecosystem services of climate-smart practices in coffee farming}

Coffee farms consist of different structural elements whose diversity is improved when climate-smart practices are adopted. Structural elements include the soil that is used, the coffee plant, different layers of overstory plants and plants that are actively or coincidently intercropped with coffee plants. Coffee plants might be intercropped with secondary crops or cover crops, as well as shade trees, windbreaks or hedges, providing an additional structural level. Together, those elements can deliver different provisioning, regulating and cultural services to the landscape and influence different aspects of human well-being, see Figure 10. For a detailed description on the mechanisms of action for some specific landscape ecosystem services see box 1 .

Provisioning services provided include the diverse products offered by the crops planted, foremost coffee, but also fruit and timber. In most cases, within the landscape only the farmers themselves will profit directly, but others may experience indirect benefits, for example when being employed for pruning or harvesting. Fuel energy and basic resources are obtained and food security is raised. Improved water quality is achieved through mitigation of water pollution, including erosion control, as well as water filtering. Therefore, contribution to human well-being is made by assuring for clean drinking water. 
Regulating services provided are especially pronounced. Coffee plants themselves, as well as climate buffering elements on farm contribute to improved regional climate and buffer extreme weather events, also on a larger scale. Together with water buffers and natural habitats on-farm, they can mitigate floods and regulate water flows. Natural habitats and structural elements can contribute to pollination and biological pest control within the landscape, as well as hindering distribution of pests and diseases. Regarding human well-being, different regulating services contribute to the aspect of security, helping to maintain a clean and safe environment to the local people and lower vulnerability to ecological stress and shocks, including climate change. Influence on health and diseases is ambiguous: though natural medicine may be gathered in natural habitats, those habitats in turn may also serve as sources of diseases affecting local population.

Cultural services might be delivered as well. In many regions especially in South and Central America coffee farming is part of the local cultural heritage and strengthens the sense of belonging. Natural habitats preserved through adoption of climate-smart practices may have recreational and aesthetic value to the people and can serve as educational space on ecosystem functioning. Moreover, parts of the farm or aligned natural habitats may serve as recreational area or induce (nature) tourism. 

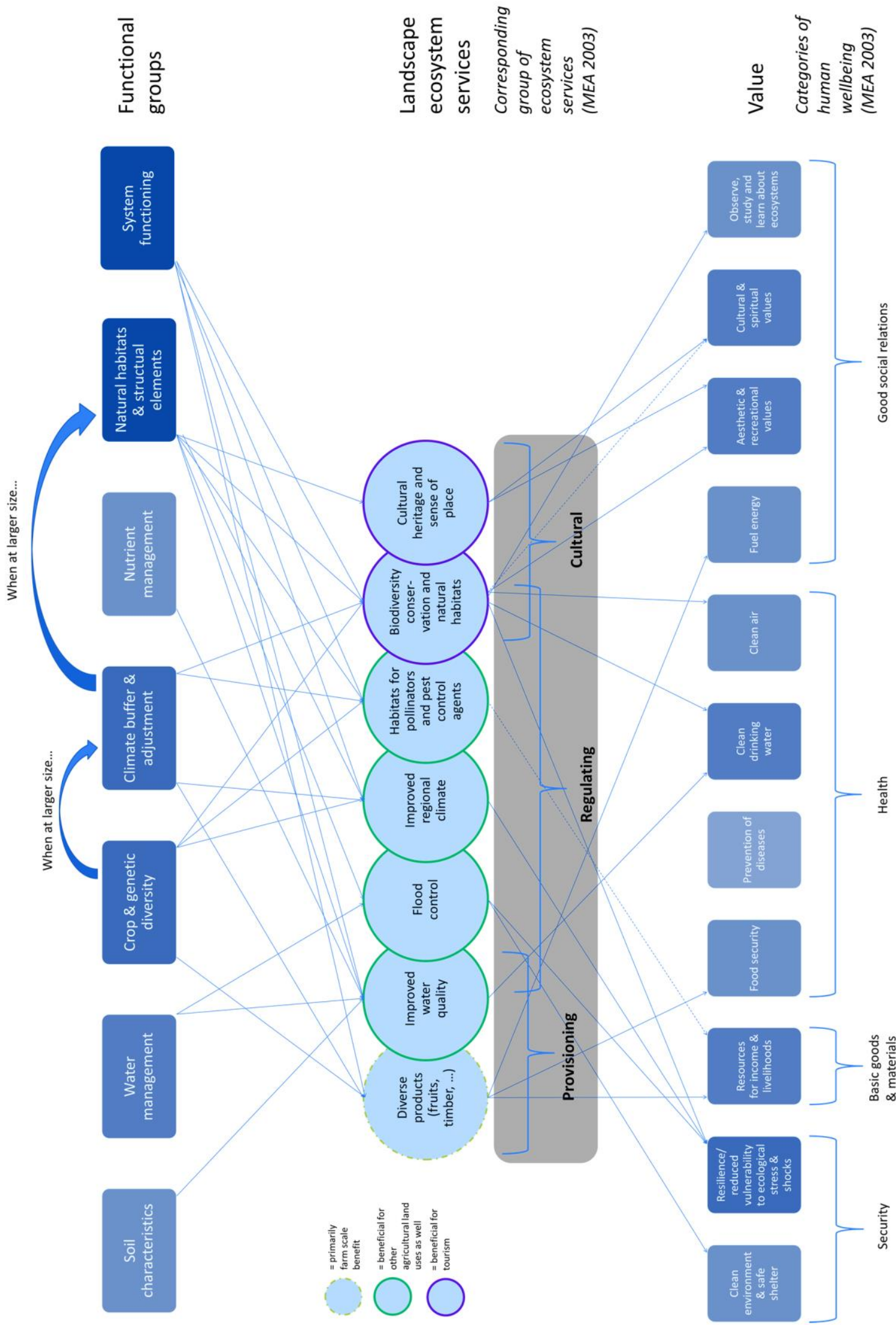

Figure 10: Overview of different landscape ecosystem services delivered by coffee farming. Also, contribution to human well-being within the landscape is indicated. Positive impacts are enhanced through uptake of climatesmart practices. Intensity of shade is proportional to number of connections i.e. importance. 
Box 1: Case studies of ways of action of different landscape ecosystem services.

- Improved water quality

Contribution of climate-smart practices on farm to improved water quality within the region takes place by three different mechanisms: Firstly, minimizing erosion lowers nutrient discharge on field and avoids overload of nutrients and suspended particles in local river basins. Functional groups that deliver those positive side effects are improving soil and water management, diversifying production and integrating elements to buffer climate extremes. Secondly, when protecting local natural habitats their water filtering function and positive contribution to local water quality is preserved. Thirdly, improving system functioning reduces need for agro-chemicals mitigating negative effects on water quality as well.

(Jha et al., 2011; Verburg et al., 2019)

\section{- Biodiversity conservation and natural habitats}

Increasing crop variety and using shading elements provides multiple microhabitats and niches for different organisms, hence contributing to biodiversity conservation. Habitat connectivity is increased, as well as landscape permeability. Improved productivity and climate resilience on-field may reduce deforestation by agricultural expansion, though adversely with more financial resources available business expansion to those areas could also be a hypothetical consequence.

(Fischer et al., 2006; Jha et al., 2011; Tscharntke et al., 2012; Verburg et al., 2019)

- Improved regional climate

Regional climate can be improved by introducing shade trees and climate buffering elements throughout the landscape and preserving natural habitats. Forests and increased crop soil covers are able to buffer extreme weather conditions like heavy rainfalls or strong winds. Moreover, higher rates of evapotranspiration can have positive impacts on cloud formation and therefore reduce the risk of droughts within the landscape, though when groundwater recharge is low, increased evapotranspiration may also lower overall water availability. Trees and shrubs augment landscape roughness, lowering wind speed and reducing risk of wind erosion.

(Ellison et al., 2017; Jha et al., 2011; Verburg et al., 2019)

\section{Habitats for pollinators and pest control agents}

Pollination and natural pest control are beneficial to coffee farming, have positive impacts on other farming activities within the landscape and may improve physiological well-being of people. Abundance and diversity of beneficial animals is increased by offering diverse habitats through crop diversification, introducing climate buffering elements or preserving natural habitats. Other land uses within the region benefit strongly from the landscape benefits mentioned, but can also contribute to them.

(Fischer et al., 2006; Tscharntke et al., 2011) 


\section{Role of spatial patterns and landscape services}

Whether or not, as well as to what extent, coffee farms can deliver positive services to the surrounding landscape depends on how farms and other land uses, and on a smaller scale their structural elements, are scattered across the landscape (Tscharntke et al., 2012). Whether the distribution of land use and structural elements within the landscape is clustered, forms blocks or linear elements is, randomly or homogeneously distributed, influences which landscape service can be delivered, see Figure 11.

Blocked patches of natural habitats like forests or trees and shrubs as structural elements can slow down wind speed, thus providing protection from windstorms, as well as slowing down spread of fungi's' spores and mitigating spread of coffee berry borer (Avelino et al., 2012).

Linear elements enhance landscape connectivity (Fischer et al., 2006; Tscharntke et al., 2012). When placed parallel to river flows, they can mitigate flooding and serve as water filtering elements additionally (Goldman et al., 2007). Clustered forests or structural elements close to and within the plantation can serve as natural habitats for biological control agents like for example birds and ants (Verburg et al., 2019). However, it has to be noted that depending on species of pollinators and trees within the patches, those elements might also lure out pollinators or host pests (Verburg et al., 2019).

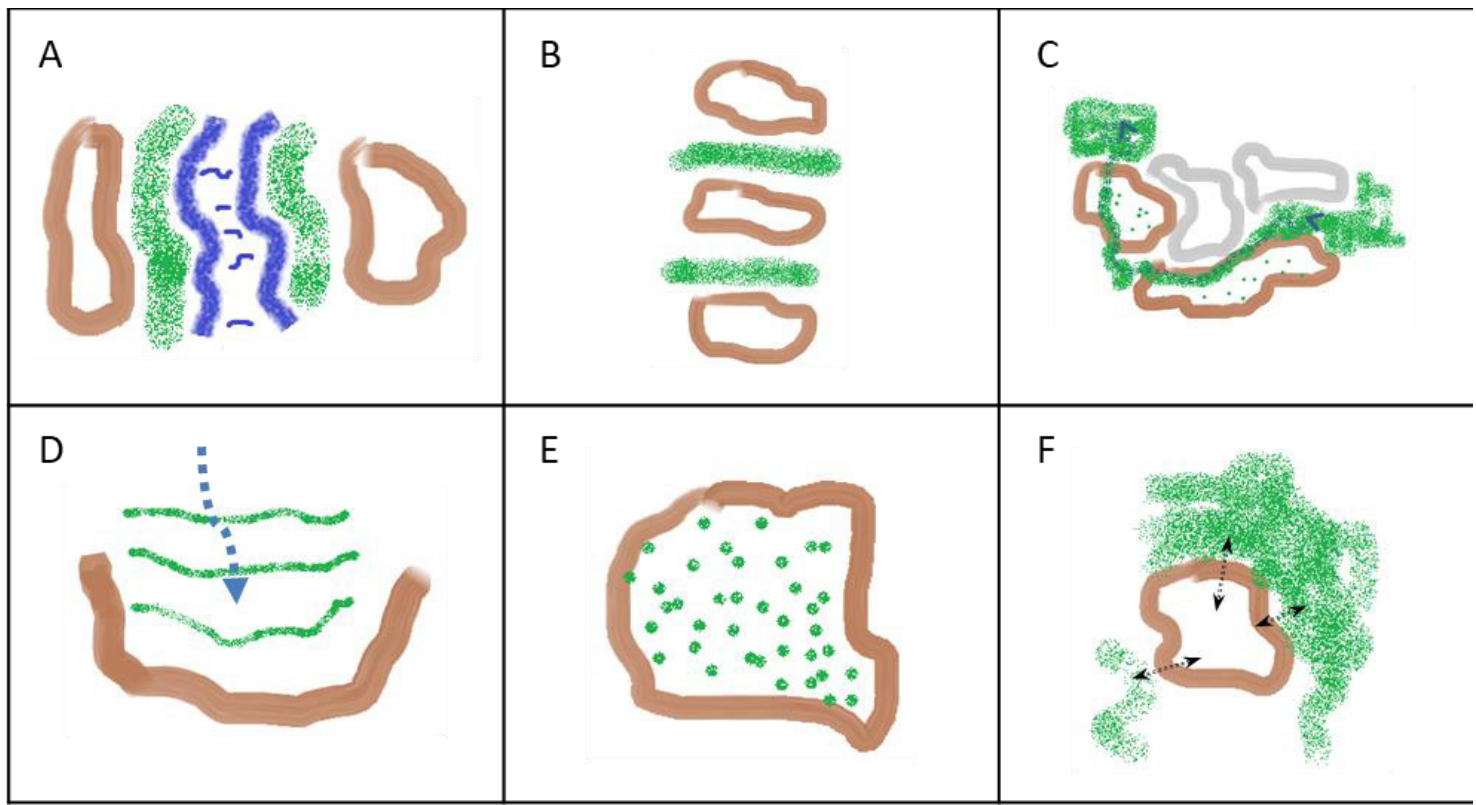

Coffee farming patches $\mid$ Natural habitats and structural elements|fig River|

other land uses

A: Green riverside elements for water filtering and flood buffering.

B: Forest blocks as seperation between coffee patches, slowing down wind speeds and spread of diseases like coffee rust.

C: Joining natural elements on-field for enhanced habitat connectivity and create natural corridors.

D: Orthogonal arrangement of blocked structural elements to slow down wind and/or water erosion as well as to protect from strong winds.

E: Integrating natural elements on-farm for higher diversity and landscape permeability.

F: Maintaining natural habitats in neighbouring areas to allow positive spill-over effects (pollination, natural pest control).

Figure 11: Possible arrangements of natural habitats and structural elements in coffee farming. According to spatial arrangement, different landscape services can be delivered. 
Mixing in natural and structural elements within the coffee farms enhances habitat permeability and on-farm biodiversity (Tscharntke et al., 2015), contributing to pollination and pest control. Furthermore, depending on species chosen and stand density, ground temperature and throughfall rates of light and rain can be altered (Verburg et al., 2019). The microclimate created influences susceptibility of disease, slowing down development rate of coffee berry borer larvae, but also potentially increasing likelihood for fungal infection (Escobar-Ramírez, Grass, Armbrecht, \& Tscharntke, 2019; Verburg et al., 2019).

Spatial arrangements of land uses and structural elements on field and within the landscape influences strongly achieving overall goals of climate-smart agriculture or secondary objectives strongly. Therefore they should always be considered when interventions are planned.

\section{II.2.3 Global benefits}

On a global scale, climate-smart practices in coffee farming contribute to the supporting service of biodiversity conservation, as well as regulating services of climate mitigation and climate cooling, see Figure 12.

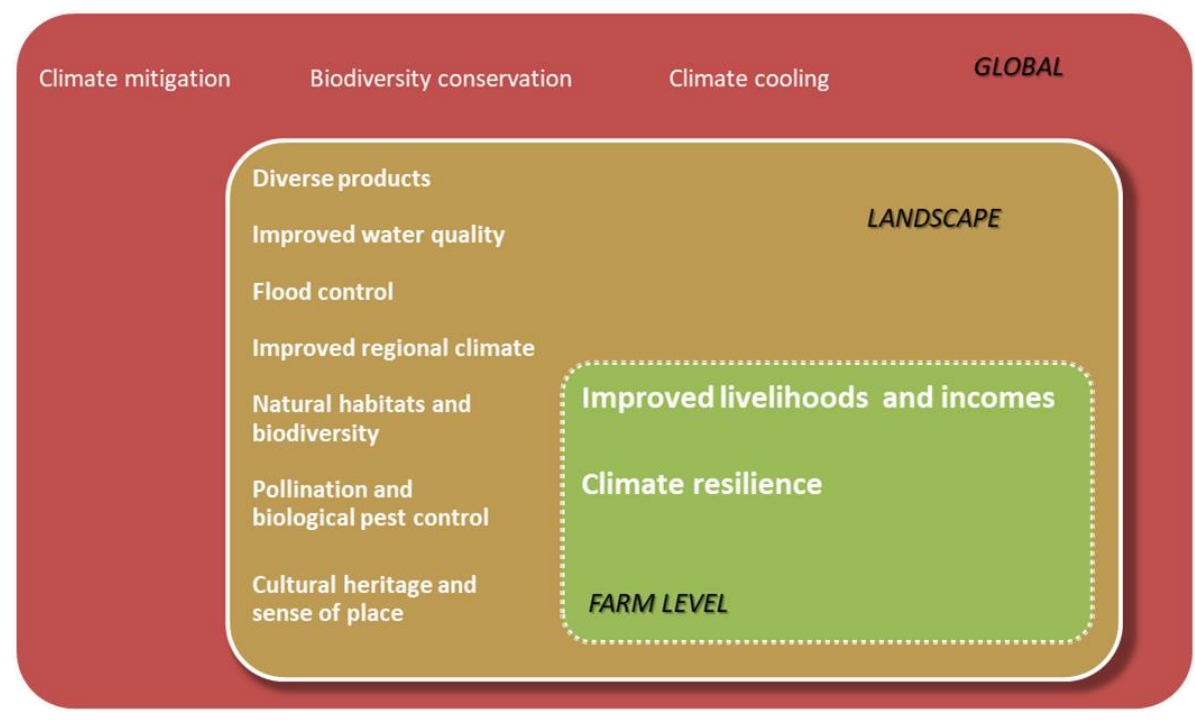

Figure 12: Overview of benefits of climate-smart practices in coffee at different scales.

Contribution to biodiversity conservation is achieved by offering new natural habitats and preserving existent ones, as well as by enhancing habitat connectivity and land-use diversity on- and off-farm, with spatial and functional diversity present (Jha et al., 2011; Tscharntke et al., 2015). This is of particular importance as coffee is farmed in the tropics, where a large share of global biodiversity is found (Pimm et al., 2014) that otherwise might be lost. Biodiversity not only holds an intrinsic value but can also be highly beneficial to mankind as native crops and animals may be the basis for new breeds or pharmaceutical ingredients (MEA, 2005).

Climate mitigation is achieved by carbon sequestration on- and off-farm, reducing carbon footprint of coffee farming, as well as preserving natural carbon sinks (Jha et al., 2011; Rahn et al., 2014). Corresponding functional groups include soil characteristics, climate buffer and adjustment, natural habitats and structural elements as well as system functioning. 
Climate cooling can be achieved when forested areas and vegetal cover are provided and preserved, lowering surface temperature by increased transpiration and redistributing solar energy (Ellison et al., 2017). Furthermore aerosols emitted can induce rain. Functional groups contributing to this service are especially natural habitats and structural habitats as well as climate-buffer and adjustment.

Climate-smart coffee landscapes offer beneficial effects at multiple scales, starting with the farmer to adopt the practices himself but providing benefits at landscape and global scale as well. Landscape ecosystem services include especially regulating services, but offer provisional and cultural services as well, contributing to various aspect of human well-being. Therefore shaping climate-smart coffee landscapes is highly desirable, though various barriers may hinder the process towards them, which will be discussed in the following chapter.

\section{II.3 Constraints to shaping climate-smart coffee landscapes}

Climate-smart coffee landscapes offer benefits at farm, landscape and global scale, but important constraints hinder shaping them. For implementation, farmers need planning reliability, proof of effectiveness of practices and sufficient economic resources, as well as knowledge how to restructure their coffee farming system to adopt climate-smart practices. Also, access to farming material needed has to be assured. Institutions should offer support to farmers to overcome constraints and actively participate in inducing change towards climate-smart coffee landscapes. However, to be able to successfully perform inclusive, cross-sectoral and long-term planning processes they still need to evolve.

One central element of climate-smart coffee landscapes is the implementation of climate-smart practices on-farm. Whether or not climate-smart practices are existent in the landscape depends on abilities and decisions of the individual farmer. Understanding farmers' perception of climate change and individual constraints to adaptation is crucial to be able to draw up supportive institutions and finance scheme. However, also obstructive institutional structures need to be understood, so that institutions can overcome them and become facilitators for change towards climate-smart coffee landscapes.

Considering the constraints, we have to look especially at two elements of climate-smart coffee landscape: (1) Practices at field and farm level - individual constraints and (2) Landscape management, coordinating practices to enable landscape wide adoption, maximize landscape benefits and minimize trade-offs - institutional constraints.

\section{II.3.1 Individual constraints - deciding on adopting climate-smart practices}

Drawing on literature on climate adaptation, climate-smart agriculture and climatesmart landscapes, I identified various individual constraints for farmers to adopt climate-smart practices. In general, studies reveal a gap between climate risk perception, often existent, and measures implemented, often insufficient (Bryan et al., 2013; Harvey et al., 2018). 
Major constraints to on-field implementation of climate-smart practices include inferior perceived relevance of climate adaptation relative to other troubling issues, uncertainty on future developments, lead time and visibility of effectiveness of measures, as well as socioeconomic situation, lack of resources, insufficient knowledge and access to material. Farmers' preferences on adoption of measures and which measures to take vary with the manner in which information is delivered.

Awareness for climate change was shown in various field studies, mainly conducted in Central America and Africa (Eakin et al., 2014; Jiri et al., 2015). Farmers experience climate change impacts already and acknowledge the need to adapt (Bryan et al., 2013; Harvey et al., 2018). Some take first actions, but many are constrained on various ways (Bryan et al., 2013; Harvey et al., 2018).

Other issues perceived as more pressing often cause that inferior relevance is given to climate adaptation, relative to other issues (Harvey et al., 2018). Shortfalls on basic requirements like food, running water or electricity hinder anticipative adaptation (Harvey et al., 2018). On the long run, without adaptation some of these issues probably will persist or even worsen, but current constraints existent already hinder future orientated action, trapping farmers in a vicious circle.

Uncertainties on future developments hinder future orientated investment in adaptation measures. Unpredictability of exact impacts of climate change together with highly volatile coffee prices make farmers flinch back from investments (Bryan et al., 2013; Eakin et al., 2014; McCarthy, N., Lipper, L., Branca, G., 2011). Likewise, insecure land tenure causes low planning reliability (Harvey et al., 2018).

Lead time and visibility of effectiveness of climate-smart practices influence whether or not practices seem relevant to farmers to be adopted (Eakin et al., 2014; McCarthy, N., Lipper, L., Branca, G., 2011). Climate adaptation presents the paradox that, in a changing climate, tacking action and adaptation of new measures is needed to be able to perform just as well as before (Stafford Smith et al., 2011). Also, if practices are adopted throughout the entire landscape, relative to others no improvement is made. Lead time of practices like integrating shade trees is long, taking years if not decades, whilst other practices like building up soil organic matter may only have diffuse effects, hard to observe as a real change but more increasing productivity and resilience slowly over a longer period of time (McCarthy, N., Lipper, L., Branca, G., 2011).

Individual socio-economic conditions, lack of financial resources or access to obtain them are further constraint to uptake of climate-smart practices and climate adaptation. Whether farmers decide on climate adaptation depends on their individual socio-economic situation and financial capacity (Jiri et al., 2015; Khatri-Chhetri, Aggarwal, Joshi, \& Vyas, 2017). Some practices may require larger investments (see listing of expected financial constraints for different climate-smart practices in CIAT (2017)). Often smallholder farmers are unable to perform these investments on their own (Bryan et al., 2013), nor do they always have access to external capital (Harvey et al. (2014) and sources within).

Regarding information and knowledge on how to implement measures, farmers may lack education (Harvey et al., 2018) or information and technical support (Bryan et al., 2013; Harvey et al., 2018). The manner in which farmers are informed on costs and benefits of climatesmart practices also shape their decision for or against them (Khatri-Chhetri et al., 2017) and individual preferences may vary with age and gender (Jiri et al., 2015; Khatri-Chhetri et al., 
2017).

Lack of access to farming materials like seedlings or crop varieties may hinder uptake further, even when knowledge and individual capacity are present, (CIAT, 2017; McCarthy, N., Lipper, L., Branca, G., 2011). With climate change altering agro-climatic zones and coffee crops normally staying in production for decades until renewed it will be of special importance for coffee farming to choose varieties consciously (CIAT, 2017; Läderach et al., 2017).

A multitude of different constraints exist, hindering farmers to adapt to climate-change anticipatory. Especially the most vulnerable smallholder farmers will often be unable to overcome those constraints to adaptation. Therefore enabling support is needed.

\section{II.3.2 Institutional constraints - facilitating and organizing}

To overcome barriers to farmers, institutions are of great importance being able to offer financial support or teachings. Relevant institutions may include coffee cooperatives, regional and national governments, roasters and trades, but also NGOs and international development organizations and funds. Within the process of integrated landscape management, they may adopt a leading role to facilitate progress towards climate-smart coffee landscapes. However, within institutions and organizations, classical thinking, organizational structures, stakeholder inclusion and ways of measuring may pose hurdles to shaping climate-smart coffee landscapes.

\section{How to think}

Traditional organizations may be challenged by the holistic and integrated thinking required for integrated landscape management and climate-smart coffee landscapes (Harvey et al., 2014; Scherr et al., 2012). Sayer et al. (2013) contrast the landscape approach from sectoral thinking: Unlike sectoral or project approaches with a clear start and endpoint, landscape approaches are a continuous process. Trade-offs might be system inherent and unavoidable, so it has to be negotiated where they are to be accepted and whether and to what extent they should be compensated (GCP, 2015). Likewise, though holistic thinking may reveal synergies, it also increases complexity of planning processes (Reed et al., 2016).

\section{How to organize}

Classical organizational structures with sectoral thinking hinder adoption of a landscape approach, as when only sectoral goals are aimed at, synergies will be hard to achieve (Harvey et al., 2014; Reed et al., 2016). Inconsistent policy strategies hinder adoption and heading towards a common goal. Funding schemes, need to be harmonized and process orientated, enabling for long term funding as change which will take time (Hart et al., 2015; Reed et al., 2016). For locally adequate solutions decentralized governance is important and stakeholders knowledge should be integrated, but at the same time effective management requires capacity (Fagerholm, Käyhkö, Ndumbaro, \& Khamis, 2012; GCP, 2015; Scherr et al., 2012).

\section{Who to include}

Including actors from multiple scales means including different approaches and views as well as different 'languages' spoken. Stakeholders need to be able and willing to try to 
understand different views and interests within the process to advance towards shared change logic (Reed et al., 2016; Sayer et al., 2013). Local knowledge is vital for adequate solutions but might need to be translated to be comprehensible for other actors as well.

In climate-smart coffee landscapes, integrating all relevant stakeholders from within the coffee chain may signify that stakeholders may be spread halfway around the globe. When integrating multiple stakeholders from different levels, managing and balancing their individual interests might be challenging, too, as minorities as indigenous communities might have opposing views on development than other actors within the region (Brandt, Kvakić, ButterbachBahl, \& Rufino, 2017). Here it has to be weighed whether consensus should be built on majority decisions or exceptions should be made (Brandt et al., 2017).

\section{How to measure}

Indicators and measurements have to be multidimensional, instead of relying only on sectoral goals (Sayer et al., 2013). The scale at which they are defined is highly relevant as different effects of practices are to be expected at different scales. The landscape scale is the central scale of operation, but field-, and farm-, and also global effects need to be considered as well, especially to avoid trade-offs like shifting problems to other regions.

Change towards climate-smart coffee landscapes is desirable but challenging. Farmers need to see relevance and effectiveness of climate-smart practices and possess sufficient capacity and knowledge to adapt climate-smart practices on-farm. Institutions may offer support and play an important role on shaping climate-smart coffee landscapes, but need to embrace a holistic view and adopt cross-sectoral management to be able to perform those two roles and play a leading role in the process of integrated landscape management. 


\section{II.4 Shaping climate-smart coffee landscapes - what is needed for implementation?}

A dual step framework of combined farm-scale based CSA assessment and landscape pattern assessment is proposed. Analysing specific climate change risks and farmers' individual vulnerabilities and capacities helps to develop tailored bundles of climate-smart practices for individual farmers. Considering spatial patterns in the landscape and vital landscape services in parallel, effectiveness of practices can be optimized and multi-scale win-win effects can be achieved.

Governments, finance and markets can act as catalysts to facilitate change towards climate-smart coffee landscapes. By integrating this dual step framework of combined farm-scale based CSA assessment and landscape pattern assessment within the process of integrated landscape management, climate-smart coffee landscapes can be shaped.

Different frameworks and tools for implementation of climate-smart agriculture and assessment of adaptation need in coffee exist already, but they either lack a landscape wide perspective, consideration of climate change coffee specific opportunities or do not consider mitigation-adaptation synergies.

Brandt et al. (2017) propose targetCSA, a framework for regional climate-smart agriculture assessment but operate more on a top down approach and do not include coffee specifics. GCP (2015) on proposing the strategy of integrated landscape management draw up a framework to shape sustainable landscapes but lack considering climate-smartness. For coffee, IITA and c\&c propose frameworks and tools to implement field based climate adaptation measures (c\&c, 2015; IITA, 2019a; IITA, 2019b) and Rahn et al. (2014) also consider synergies with mitigation. However, they do not consider landscape wide synergies and consideration of importance of spatial patterns. The Sustainable Food Lab \& CIAT (2019) go a step further, recognizing need for climate-smartness in coffee farming and integrating actors from the coffee value chain but lack consideration of landscape dependencies and opportunities.

I build up on these frameworks and tools, and include my findings from the previous chapters, to be able to draw up a consistent framework for shaping climate-smart coffee landscapes. Findings are restructured first, before outlining the dual step framework and possible catalysts.

\section{II.4.1 Restructuring findings - The winning Ws for implementation}

Climate-smart coffee landscapes include climate-smart practices at field and farm level, while integrating a diversity of land uses and management of interactions. They offer benefits to the farmer, especially in terms of improved livelihoods and climate-resilience. On the landscape and global scale, they proof desirable because of their synergistic potential for achieving neighbouring objectives like biodiversity conservation and securing vital ecosystem functions also for other land users within the landscape. However, constraints regarding the socioeconomic situations of the farmers, lead time of practices and lack of knowledge, as well as insufficient institutional support or sectoral organizational structure hinder progress towards 
climate-smart coffee landscapes.

To overcome constraints and enable for effective implementation, 8 leading questions are phrased, that need to be considered, see Table 2. Their logical order will serve as a guideline during the analytical processes within the framework proposed.

\begin{tabular}{|c|c|}
\hline Why? & $\begin{array}{l}\text { 1. Understand impacts of climate change and } \\
\text { adaptation needs. }\end{array}$ \\
\hline Where? & $\begin{array}{l}\text { 2. Recognize local environmental conditions and } \\
\text { spatial patterns. }\end{array}$ \\
\hline Who? & $\begin{array}{l}\text { 3. Study individual capacity, vulnerability and } \\
\text { resilience of farmers. }\end{array}$ \\
\hline What else? & $\begin{array}{l}\text { 4. Consider needs to be met beforehand to facilitate } \\
\text { implementation of climate-smart practices. }\end{array}$ \\
\hline Which tools? & $\begin{array}{l}\text { 5. Choose tools that are adequate for local } \\
\text { conditions, and adapted to farmers' individual } \\
\text { knowledge, capacities and cultural backgrounds. }\end{array}$ \\
\hline What money? & $\begin{array}{l}\text { 6. Be aware of financial resources. If insufficient } \\
\text { consider alternative sources of funding. }\end{array}$ \\
\hline How? & $\begin{array}{l}\text { 7. Identify knowledge needed and possibilities for } \\
\text { knowledge transfer. }\end{array}$ \\
\hline When? & $\begin{array}{l}\text { 8. Consider time-lag between implementation and } \\
\text { benefit. Understand coffee farming cycles and } \\
\text { time frames to implement change. }\end{array}$ \\
\hline
\end{tabular}

General answers to questions 1, 2, 6 and 8 were given in part I, while questions 2-5 were answered in the previous chapters of this part. The framework provided will help to answer the question in a structured way, highlighting relevance of adaptation and potential for synergies, and operationalizing those answers for positive on-ground action.

\section{II.4.2 The dual step framework}

A dual step framework is proposed with two analytical processes for identifying synergies between on-farm adaptation of climate-smart practices and landscape benefits. As part of a landscape wide process of integrated landscape management, a farm-scale based CSA assessment and a landscape pattern assessment are to be performed, see Figure 13. The framework lays a special focus on the analytical steps needed to tailor climate-smart practices in coffee farming to local conditions and find locally adequate solutions.

\section{Farm-scale based CSA assessment}

To be able to develop locally adequate climate adaptation strategies, understanding local climate risk and spatial patterns, as well as human factors and capabilities is important. 
Adaptation strategies should be tailored to local needs and the specific agro-ecological context (Harvey et al., 2018; Khatri-Chhetri et al., 2017). In most of the cases financial and organizational resources will be limited, so focus should be laid on no-regret strategies, i.e. strategies that proof beneficial even when climate-change impacts differ from those initially predicted (GCP, 2015).

Within the farm-scale based CSA assessment, two analytical steps need to be performed, regarding (1) climate change and climate risk and (2) vulnerabilities and capacities. Farm level interventions then can be embedded within the wider scope of securing landscape services, recognizing important patterns and considering contribution of farm scale actions to landscape sustainability.

\section{(1) Climate change and climate risk}

This step aims at assessing the site specific adaptation need. Firstly, based on climate prediction models it should be analysed what climate change impacts on local coffee farming are to be expected. Adaptation classes can then be assigned to each area, according to the severity of climate change impacts, future suitability for coffee farming and the necessity for adaptation to climate change. Adaptation classes may differentiate between regions with incremental systemic and transformative adaption need, using for example predicted shifts of agro-ecological zones as indicators (Bunn, Läderach, Pérez Jimenez, Montagnon, \& Schilling, 2015b). A more site specific analysis on local bioclimatic situations as soil quality, water abundancy and slope exposition, should identify which functional groups of climate-smart practices are needed most. Different functional groups might be needed depending on whether soil characteristics should be improved or water management, or whether genetic and crop diversity seem to be more relevant for the specific situation.

\section{(2) Vulnerability and capacity}

However, severity of climate change impacts also differs with individual vulnerability and capacity. Therefore an assessment of individual vulnerabilities and capacities should be performed. Assessment for farmers' vulnerabilities and capacities need to include indicators of social and economic dimensions (see Rahn et al. (2014) and Brandt et al. (2017) for examples). To be able to develop tailored adaptation strategies to farmers, target groups can be defined using the farmer segmentation tool (IITA, 2019b). Indicators can include land and labour but also functional indicators as motivation and training. Corresponding to each group, most appropriate climate-smart practices can be selected. Findings from climate change and climate risks analysis are to be integrated here, to choose those practices with highest suitability for the individual situation. To be able to deliver and implement climate-smart practices, they should be organized in climate-smart bundles by using for example the tool of climate-smart investment pathways (IITA, 2019a). Those bundles then can be delivered as teaching session to farmers, for example in one year, while the following year will build up on the knowledge acquired and teach new, more advanced practices, thereby strategically increasing climate resilience while recognizing limited time and financial capital. 


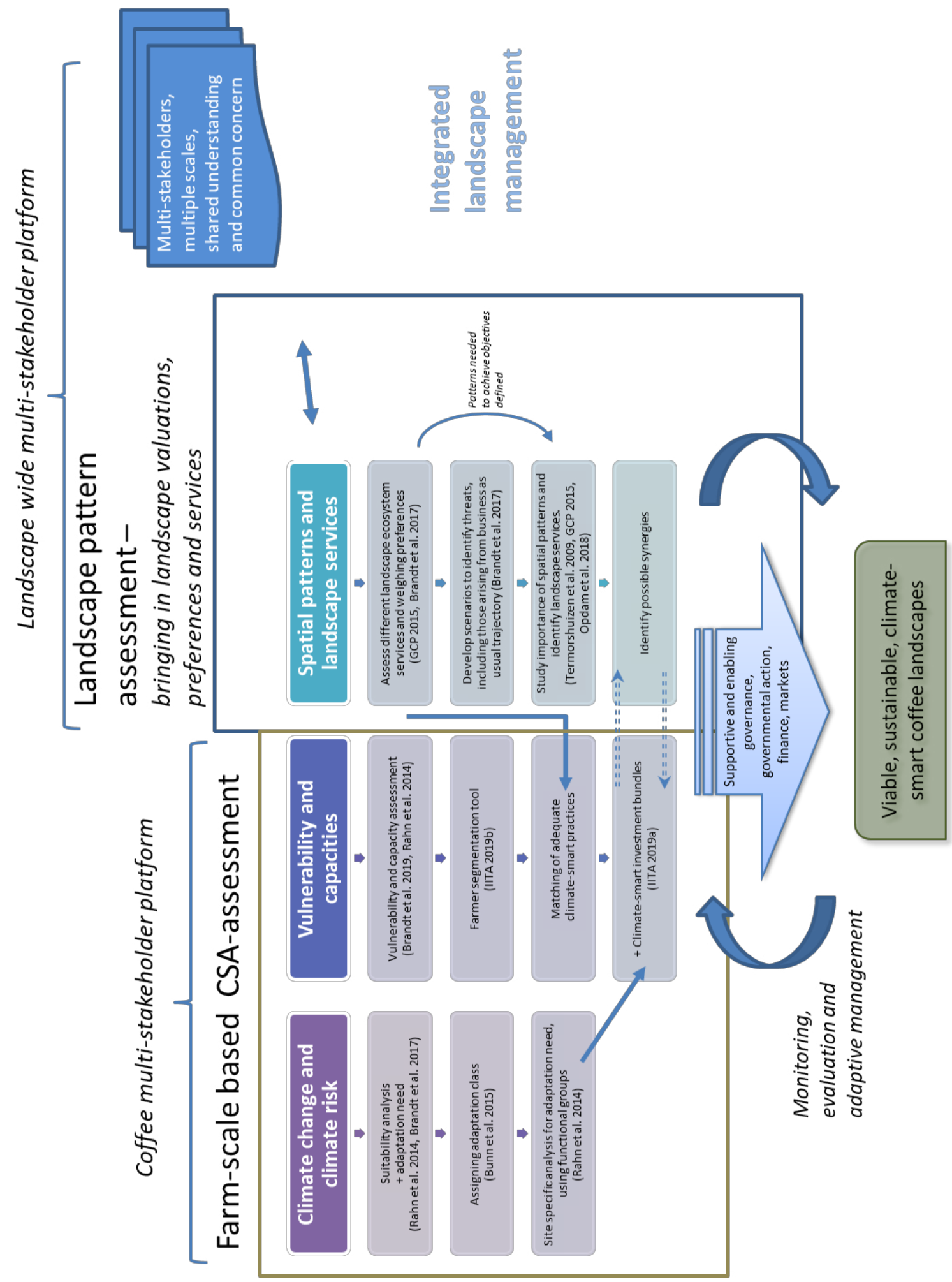

Figure 13: The dual step framework. Process of integrating farm-scale based CSA assessment for climate-smart coffee within the wider context of advanced landscape assessment, laying grounds for climate-smart coffee landscapes. Names in Hyphens indicate possible tools and frameworks that steps can be based on. 
The farm-scale based CSA assessment can be performed primarily focussing on the coffee sector and focussing on the farm scale. Only a limited number of actors need to be integrated, mainly including actors from the coffee sector. Assessing climate change impacts and risks, as well as individual vulnerability and capacities, facilitates for choosing appropriate tools and planning of farm level intervention. However, spatial patterns and landscape services should be considered as well as when practices are to be chosen as coffee is interdependent with them. Therefore, the landscape pattern assessment needs to be performed.

\section{Landscape pattern assessment}

The landscape pattern assessment aims at identifying spatial patterns and landscape services of crucial importance to the actors within the landscape, to be able to link farm based adoption of climate-smart practices to landscape wide processes. The assessment should be performed as part of a landscape wide process of integrated landscape management, drawing on the multi-stakeholder platform as a central agora.

Those ecosystem services that proof vital for the people in the landscape should be identified, using for example the targetCSA tool by Brandt et al. (2017). Consensus can be found weighing preferences, either drawing on majority votes or integrating greater consideration of differing choices of minorities also (see Brandt et al. (2017), but also Fagerholm et al. (2012)). Scenarios are to be developed to identify and highlight possible threats to core services and consequences of following the business-as-usual trajectory (Brandt et al., 2017; GCP, 2015).

Spatial patterns should be studied to identify those spatial arrangements needed to achieve the objectives defined beforehand (drawing for example on Termorshuizen and Opdam (2009), GCP (2015) or Opdam et al. (2018)). On linking this analysis to the climate-smart bundles defined during the farm-scale based CSA assessment, desirable patterns and possibilities for winwin situations can be achieved. And with the help of supportive and enabling governance and financing, and drawing on markets, progress can be made towards viable and sustainable climate-smart coffee landscapes.

\section{II.4.3 Catalysts for change}

Catalysts for change facilitate shaping of climate-smart coffee landscapes. Scherr et al. (2012), on proposing the concept of climate-smart landscapes, list 4 institutional mechanisms to be of special importance for implementation: (1) multi-stakeholder planning, (2) supportive governance and resource tenure, (3) financing for integrated landscape inventions and (4) tracking of multiple dimensions of change. I will adapt those mechanisms to coffee dominated landscapes and, drawing on GCP (2015), I will discuss the role of markets as a fifth catalyst additionally. The catalysts influence distinct parts of the process of shaping climate-smart coffee landscapes. The multi-stakeholder platform lays the foundation to establish an efficient landscape wide process and will stay of crucial importance throughout the entire process. Governments, finance and markets should be considered during the process for strategic cooperation Tracking change is especially important when first on-ground action are taken to identify misdevelopments early on and enable for adaptive management. 


\section{(1) Establishing a multi-stakeholder platform and multi-stakeholder planning}

Landscape actors need to be brought together within multi-stakeholder platforms. In coffee landscapes the dominating land use is coffee farming. Cooperatives and labelling boards, as well as local or national coffee research institutes might take strong leadership, establishing a multi-stakeholder platform to integrate different preferences holistically. Not only actors from within the landscape should be present, but also actors from the value chain, as it is of great importance for coffee production.

\section{(2) Offering supportive landscape governance and clarifying resource tenure}

Institutional and governmental conditions are of high importance, as they promote or inhibit change. Depending on policy instrument chosen, governments can act as enforcing, promoting or informing agent (van Noordwijk et al., 2015). Supportive governmental action can include facilitating decentralized governance to find locally adequate solutions (Scherr et al., 2012), but also enabling for cross-sectoral organization (Sayer et al., 2013). Clarifying resource and land tenure enables future orientated action (Scherr et al., 2012). Law making and enforcement may be needed to assure for minimum standards, but the state also needs to be capable to efficiently monitor and enforce law.

Governance action does not need to be restricted to local or national policies, but should also be induced through international actions. Possible examples are agreements on carbon compensation payments or national carbon taxes in consumer countries. Similarly, institutional policies, also of companies, can set free significant monetary resources, for example by aiming towards carbon neutrality within the value chain.

\section{(3) Enable for integrated landscape investment and finance}

To create climate-smart coffee landscapes, financial resources are needed. Implementation of some measures might pay-off for farmers directly, but many practices have a larger timescale of financial amortisation. Implementation of new coffee varieties or planting of shade trees are examples of climate-smart practices with large time-lags, paying-off only years after planting. Therefore, financing for transition is needed. Loans or initial funding may be sufficient to facilitate adoption of some practices, others will need continuous financing, like knowledge transfer and monitoring of progress made.

Funding can be obtained from within the value chain, national or international funds but also from impact investors (Harvey et al., 2014; Scherr et al., 2012). As coffee traders and roasters may be intrinsically motivated to sustain their supply chains and to secure sufficient production and quality of the coffee available, they might also be willing to finance change. Large funds for implementing climate-smart coffee landscapes include those applicable under the UNFCC (United Nations Framework Convention on Climate Change), including clean development mechanisms, adaptation funds and the GEF (Global Environmental Facility), see FAO (2010b) and FAO (2013) and CGIAR (2018) for an overview. Impact investors try not only to optimize financial revenue but also aim for social or environmental benefits of their investments. For climate-smart coffee landscapes, rootcapital might be an impact investor of great importance, aiming at social and environmental investments in Africa as well as in Central and South America (see rootcapital (2020) and Winget et al. (2017)). In landscapes where funding can be obtained from such a multitude of different sources, financing schemes should be harmonized and made comprehensible, to be relevant to local farmers (Harvey et al., 2014). Cooperatives or national to regional coffee institutes can act as central player, 
connecting international funders to local farmers, drawing attention on support needed or offering micro-credits to the local farmers within the landscape, but also acting as counsellor to them and supportive voice of them. They can highlight possibilities for payments for ecosystem services and carbon compensation payments and can give first estimations on how schemes have to be drawn up to be relevant to local coffee farmers.

\section{(4) Discovering markets to support climate-smart coffee landscapes}

Through markets, different benefits of climate-smart coffee landscapes can be valued and costs refunded. Markets can not only include commodities, but also ecosystem services (payments for ecosystem services) or carbon compensation payments. Furthermore, using labels and certification marks can justify higher prices linked to complying with above baseline standards, see box 2 .

Creating a label for climate-smart coffee landscapes may set free additional financial resources to support transformation. Classical certification marks, like for example Fairtrade, organic or bird-friendly coffee, are primarily focused on a farm scale or only relate to the coffee value chain. They set specific rules producers and actors within the value chain have to comply with. A label for climate-smart coffee landscapes could be linked to them, but should go further and include a landscape perspective. Labelling could embrace the concept of UNESCO's Man and the Biosphere programme (UNESCO, 2020b) and relate to protected geographical indications (GI). Incomes from certification can be redistributed within the landscape (Ghazoul, Garcia, \& Kushalappa, 2009), for example by coffee cooperatives, national or regional coffee institutes or local governments, to finance progress within the entire climate-smart coffee landscape.

\section{(5) Tracking change}

For adaptive management, progress should be monitored, considering multiple dimensions of change. Tracking change contributes to higher effectiveness of measures taken, as possible problems can be identified and efficiency of different practices can be evaluated, enabling a learning process (GCP, 2015). Where possible, existing data should be used to reduce management and data assessment costs (GCP, 2015).

Indicators used should be based on the common set of objectives earlier defined including social, economic and ecological dimensions, as wee as carbon savings (e.g. by using the cool-farming tool (CFA, 2020)) and increased climate resilience of farmers. Methodologically, different approaches should be combined, including interviews of farmers to include local knowledge (see: Castellanos et al. (2013)), expert interviews, on-field measurements and production data of goods within the landscape, to be able to capture a multiscale picture.

Remote sensing by satellites and drones can contribute to track change, offering data comparably cheap for a greater region, to analyse landscape scale impacts and landscape functioning. Indicators can include for example deforestation rates, surface temperatures and surface albedo, as well as habitat connectivity or particle suspension rates in rivers. 
Box 2: Examples of possible market based incentives for climate-smart coffee landscapes.

\section{- Payments for ecosystem services}

Payments for ecosystem services offer farmers price premiums when they opt for certain management techniques that preserve certain ecosystem services. In Costa Rica, for example since 1997 payments are made to farmer when maintaining forested areas (Wallbott, Siciliano, \& Lederer, 2019). Another example includes localized payments in the community of Jesú de Otoro, where coffee farmer are refunded for treatment of process water to preserve local water flows (Williams-Guillén \& Otterstrom, 2014).

\section{- Carbon compensation payments}

Carbon compensation payments may stem from national or international funds, but can also be made by companies or individual consumers. First efforts to link divergent carbon compensation payments to local climate mitigation strategies are already existent. One example is the case of the 'Gold Standard', joining forces with the Fairtrade foundation to offer opportunities for carbon compensation payments to companies (see Fairtrade Foundation (2018) and Gold Standard (2014)). Also in coffee, some initiatives already try to inset carbon directly within the production chain, labelling coffee as low carbon, with the initiative of NAMA café from Costa Rica as an example (see NAMA Café (2020)).

- Landscape related labels

Labels should not be restricted to single farm action but should include the entire region as done whithin the concepts of UNESCO biosphere reserves or geographical indications. Some UNESCO biosphere reserves explicitly relating to coffee exist already, including the biosphere reserves of El Triunfo in Mexico (UNESCO, 1993), Apaneca-Ilamatepec in El Salvador (UNESCO, 2007) and Yayu in Ethiopia (UNESCO, 2010). Probably the most famous example for connecting certification marks, geographical indications and landscapes in the coffee sector is Café de Colombia which strategically built up international reputation to assure higher prices for Colombian coffee produces since the 1950s. The strategy includes combining a distinctiv trade mark, Juan Valdez, with the certification mark Café de Colombia, as well as creating a protected geographical indication (WIPO, 2015). Even though law enforcement to protect the distinctive label and integration of multiple producers is said to be challenging, WIPO (2015) reports the strategy to be proofed successful in achieving up to $20 \%$ higher selling prices for Colombian coffee.

The dual step framework serves as a first attempt to combine assessment of opportunities of climate-smart practices on-farm with recognized importance of landscape services and integrate both within a landscape wide process of shaping climate-smart landscapes. Climate-smartness should be considered at all steps of integrated landscape management: Shared understanding should include effects of climate change on different actors. When change is planned collaboratively, the objectives of climate-smart agriculture, livelihoods, adaptation and mitigation should be recognized and adopted for coffee farming practices as seen above, while 
monitoring may include climate related indicators.

Due to climate change uncertainty, time lag of measures taken and above all the complex nature of the problem the process will be cyclical with a continuous need for adaptation Therefore, long term commitment and finance are needed. 


\section{Conclusion and outlook - Climate-smart coffee landscapes in a changing climate}

\section{III.1 Conclusion}

This thesis structured the new emerging field of climate-smart coffee landscapes. Literature on climate-smart agriculture and climate-smart landscapes, as well as climate adaptation and mitigation in coffee farming was structured.

The concept of climate-smart landscapes was applied to coffee dominated regions, to be able to define key elements of climate-smart coffee landscapes, see Figure 14. Coffee as a plant being a woody perennial that can be farmed within agroforestry systems allows for high diversity and carbon stocks already on field, while the strong connection to international markets may enable financial resources for change.

It was evaluated what farm scale benefits are to be expected and how private scale climate-smart practices in coffee faring can lead to synergies on the landscape scale and may also deliver global benefits. The farmer himself may profit from improved livelihoods, incomes and climate resilience. For the landscape, implementation of climate-smart practices throughout the landscape offers especially regulating services related to water quality and flood mitigation, pollination and pest control and improved climate, but provisional and cultural services are delivered as well. Contributions to human well-being include increased climate resilience and incomes, maintaining a safe environment, as well as social relations.

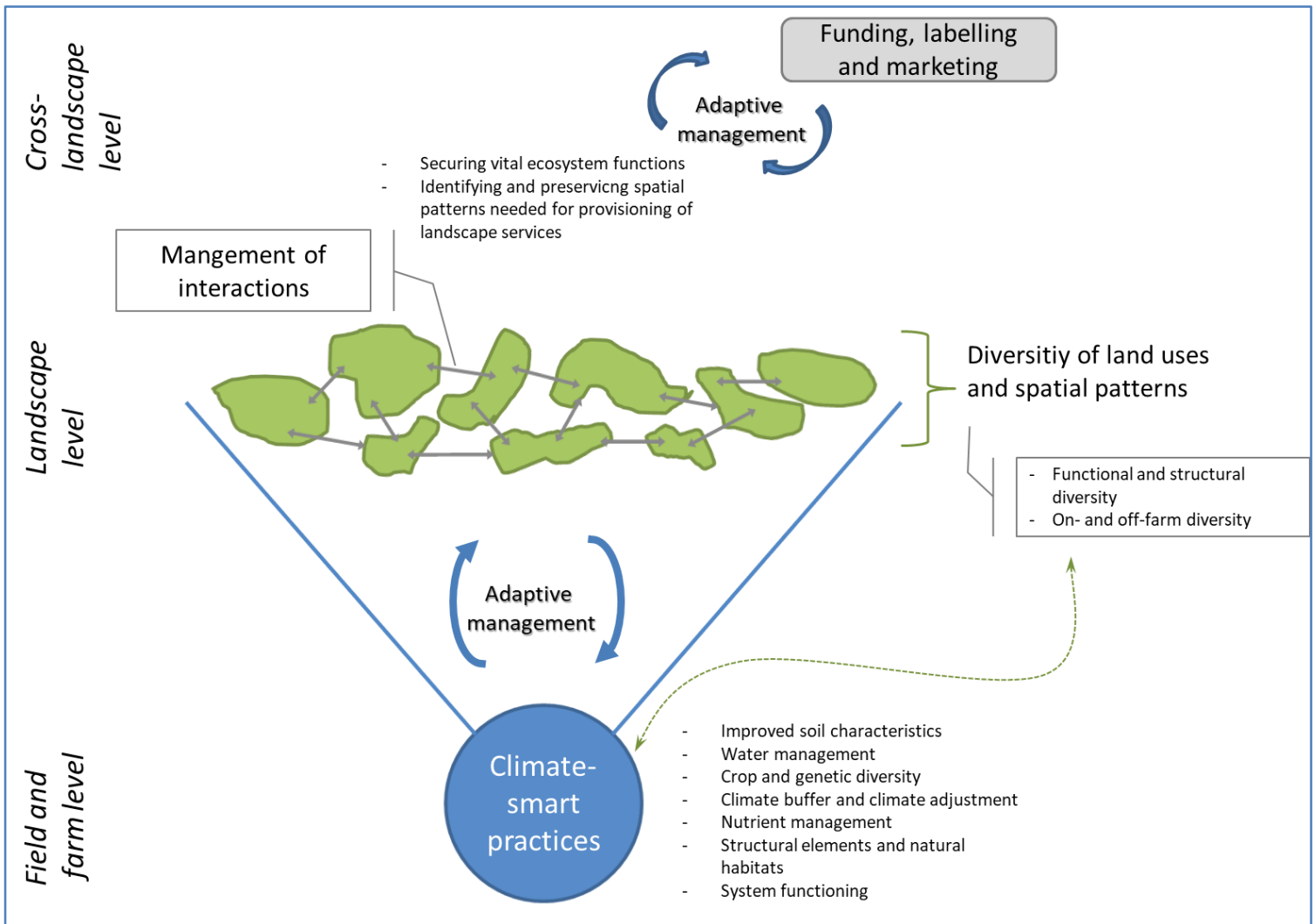

Figure 14: Visual definition and key elements of climate-smart coffee landscapes. 
Possible constraints were identified especially related to farmers' socio-economic condition, lead-time of practices but also challenges integrated landscape management and holistic thinking poses to institutions.

Based on this, a dual step framework was developed, tailoring climate-smart practices to local adaptation needs, while recognizing spatial patterns and interdependence with landscape services. By acknowledging the importance of spatial patterns, as well as relating the framework to a landscape wide process of integrated landscape management, synergetic potential can be tapped, to deliver additional landscape services and to improve living conditions landscape wide, as well as to deliver global benefits. Catalysts for change were discussed and how coffee value chain actors, governments, markets and impact investors can participate in the process of shaping climate-smart coffee landscapes.

\section{III.2 Outlook}

From there on, new fields need to be explored, considering also climate mitigation potential of coffee processing and integrating knowledge from social and economic sciences, hence moving towards on ground action to make a change in coffee regions threatened by climate change.

\section{Studying further the role of processing and coffee value chain}

Focussing not only on agricultural practices, but also studying agricultural households and integrated food energy systems may reveal possibilities for further climate mitigation potential in coffee farming (Bogdanski, 2012; FAO, 2013). Timber, prunings and fuelwood from shade trees, but also wastes from processing can be used as fuelwood and may decrease deforestation rates, preserving carbon sinks and can substitute for fossil fuels (CIAT, 2017).

Though farm based measures already provide great carbon mitigation potential, for reduction of coffee GHG-emissions, also contribution of processing further down the value chain has to be considered (van Rikxoort et al., 2014). Depulping and fermentation still remain with great potential to reduce GHG-emission and environmental effects, for example when wastewater is treated, wastes are reused as fertilizers (Rahn et al., 2014) or dry processing is performed (CIAT, 2017).

Great emission within coffee value chains are energy related, especially those caused by roasting and preparation (Kilian, Rivera, Soto, \& Navichoc, 2013). Use of renewable energy systems and higher energy efficiency would allow for great savings here (Salomone, 2003).

Whether compensating emissions by on-farm carbon sequestration proofs economic also depends on operational rules and positive or negative incentives imposed by governments (e.g. carbon taxes), companies decision and consumers' choice, which need to be explored further. Using the TEEBAgriFood Evaluation Framework, which was already applied to another woody perennial, oil palms (see: TEEB (2020) and TRUCOST (2016)) and adapting it to coffee production may lay ground for evaluating costs of services and disservices of coffee farming. Levels of 'fair' compensation payments could be estimated using an opportunity cost approach (Suyanto, Ekadinata, Mulia, Johana, \& Widayati, 2015).

Also, it remains to explore whether a certification mark as climate-smart coffee landscape can be positioned effectively within the market, how common standards can be 
implemented and assured and how earnings can be redistributed and invested within the landscape to improve livelihoods of all the people living within it.

\section{Including knowledge from social sciences}

Using insights from social sciences and studying cultural and social landscape services can reveal interconnectedness and further beneficial effects of climate-smart coffee landscapes on psychological well-being and sense of belonging, amongst others. The coffee cultural landscape of Colombia for example was listed even in the UNESCO World Heritage List in 2011 (Silva, 2017; UNESCO, 2020a), showing its value as part of the local cultural heritage. The concept of nature's contribution to the people recognition of different landscape perspectives (Díaz et al., 2018; Pascual et al., 2017) might contribute to analysis here.

Moving from theory into practice, psychology and social science are needed to optimize the process of shaping climate-smart coffee landscapes, especially regarding stakeholder interaction within the process of integrated landscape management and the long-term commitment of donors. Also communication strategies to deliver tailored climate-smart practices to farmers should be developed.

\section{Heading to new regions and consider other crops}

Focus region of most was Latin American and Africa. However, the Asian region contributes strongly to global coffee production as well. Studying coffee systems in Asia more closely might broaden views and deliver additional insights.

Secondary crops within the coffee dominated landscape should be studied case specific, to analysing interaction between different crops in the landscape to find optimize arrangements.

Findings were mainly presented for regions dominated by coffee farming, but are applicable to other tropical woody perennial understory crops as well, like cacao for example. They might also apply to other tropical agroforestry production systems like vanilla farming and maybe even for temperate agroforestry systems or farming of woody perennials as well.

\section{Bringing climate-smart coffee landscapes on the ground}

Field trials like the global coffee monitoring program of World Coffee Research (WCR, 2020) help to identify potential of different climate-smart practices under local conditions. They can also serve as explanatory field for teaching farmers and to show effectiveness of different practices. A first step towards implementation could be integrating farm-scale based CSA assessment in existing landscape management processes in coffee regions, thereby testing practicability of the framework and develop it further. But in the end, to proof effectiveness and assure viability of global coffee farming, it is of central importance to bring the entire framework into action, while assuring stakeholders long-term commitment as processes will take time. 


\section{Annex}

\section{A. Supplementary material}

\begin{tabular}{|c|c|c|}
\hline \multirow[t]{2}{*}{$\begin{array}{l}\text { Source, } \\
\text { topic of source } \\
\text { types of } \\
\text { practices }\end{array}$} & \multicolumn{2}{|c|}{$\begin{array}{l}{ }^{+} \text {CSA refers to climate-smart agriculture } \\
{ }^{*} \text { a \& } m \text { refers to combined adaptation and mitigation } \\
{ }^{1} \text { special focus on Nicaragua } \\
{ }^{2} \text { special focus on Honduras / Central America }\end{array}$} \\
\hline & \multicolumn{2}{|l|}{ Practices named: } \\
\hline \multirow{7}{*}{$\begin{array}{l}\text { Scherr et al. } \\
(2012), \\
\text { CSA }^{+} \text {in } \\
\text { general, } \\
\text { CSA }\end{array}$} & Forest management & $\begin{array}{l}\text { Improved irrigation } \\
\text { techniques }\end{array}$ \\
\hline & Soil organic matter & Green manure \\
\hline & Cover crops & Nitrogen-fixing crops \\
\hline & Crop residues & $\begin{array}{l}\text { Organic-farming and non- } \\
\text { synthetic nitrogen inputs }\end{array}$ \\
\hline & Permanent soil cover & Agroforestry \\
\hline & $\begin{array}{l}\text { Improved irrigation } \\
\text { management }\end{array}$ & Live fences \\
\hline & $\begin{array}{l}\text { Water harvesting and contour } \\
\text { farming }\end{array}$ & \\
\hline \multirow{11}{*}{$\begin{array}{l}\text { FAO (2013), } \\
\text { CSA in general, } \\
\text { CSA }\end{array}$} & Ecosystem-based approaches & $\begin{array}{l}\text { Restoration of cultivated } \\
\text { peaty soils and degraded lands }\end{array}$ \\
\hline & Conservation agriculture & $\begin{array}{l}\text { Soil management practices } \\
\text { that reduce fertilizer use (e.g. } \\
\text { urea deep placement) }\end{array}$ \\
\hline & $\begin{array}{l}\text { Integrated nutrient and soil } \\
\text { management }\end{array}$ & $\begin{array}{l}\text { Integrated nutrient } \\
\text { management }\end{array}$ \\
\hline & Organic agriculture & Irrigation \\
\hline & Cover cropping & Integrated crop systems \\
\hline & Crop diversification & $\begin{array}{l}\text { Dedicated energy crops to } \\
\text { replace fossil fuel use }\end{array}$ \\
\hline & $\begin{array}{l}\text { Using high quality seeds and } \\
\text { planting materials of adapted } \\
\text { varieties }\end{array}$ & $\begin{array}{l}\text { Emission control and } \\
\text { reduction (combustion } \\
\text { engines, animal waste) }\end{array}$ \\
\hline & Integrated pest management & Grassland management \\
\hline & Integrated weed management & Agroforestry \\
\hline & $\begin{array}{l}\text { Land fragmentation (mixing in } \\
\text { riparian areas and forest land } \\
\text { within agricultural land) }\end{array}$ & Water table management \\
\hline & Promotion of legumes & \\
\hline
\end{tabular}


Table I (continuation I): Farm-level based practices suggested in literature to be applicable for climate-smart agriculture or offering combined adaptation and mitigation potential. Already refined for coffee relevant practices.

\begin{tabular}{|c|c|c|}
\hline \multirow[t]{2}{*}{$\begin{array}{l}\text { Source, } \\
\text { topic of source, } \\
\text { types of } \\
\text { practices }\end{array}$} & \multicolumn{2}{|c|}{$\begin{array}{l}{ }^{+} \text {CSA refers to climate-smart agriculture } \\
* \text { a \& } m \text { refers to combined adaptation and mitigation } \\
1 \text { special focus on Nicaragua } \\
{ }^{2} \text { special focus on Honduras / Central America }\end{array}$} \\
\hline & \multicolumn{2}{|l|}{ Practices named: } \\
\hline \multirow{8}{*}{$\begin{array}{l}\text { Harvey et al. } \\
(2014) \text {, } \\
\text { CSA in general, } \\
\text { a \& m }{ }^{*}\end{array}$} & $\begin{array}{l}\text { Integrated soil and water } \\
\text { conservation efforts }\end{array}$ & $\begin{array}{l}\text { Conservation and restoration } \\
\text { of surrounding forest habitat }\end{array}$ \\
\hline & $\begin{array}{l}\text { Organic fertilizers and cover } \\
\text { crops }\end{array}$ & $\begin{array}{l}\text { Conservation and restoration } \\
\text { of surrounding riparian areas }\end{array}$ \\
\hline & Maintenance of crop residues & $\begin{array}{l}\text { Sustainable intensification to } \\
\text { reduce pressure on fragile } \\
\text { areas }\end{array}$ \\
\hline & $\begin{array}{l}\text { Breeding crop varieties for } \\
\text { shade tolerance }\end{array}$ & $\begin{array}{l}\text { Improved nutrient } \\
\text { management }\end{array}$ \\
\hline & Use agroforestry & Maintain mulches \\
\hline & $\begin{array}{l}\text { Diversification of cropping } \\
\text { system }\end{array}$ & Intercropping \\
\hline & $\begin{array}{l}\text { Soil conservation, including } \\
\text { terracing and land contouring }\end{array}$ & $\begin{array}{l}\text { Reduced expansion of } \\
\text { cropland into remaining } \\
\text { natural habitat }\end{array}$ \\
\hline & Use of cover crops & Integrated pest management \\
\hline \multirow{7}{*}{$\begin{array}{l}\text { c\&c (2015), } \\
\text { coffee specific, } \\
\text { adaptation }\end{array}$} & New varieties & Windbreaks \\
\hline & Pruning of coffee plants & Changed planting dates \\
\hline & $\begin{array}{l}\text { Grafting Arabica cion onto } \\
\text { Robusta rootstock }\end{array}$ & Changed planting distances \\
\hline & Enhanced pest management & Diversified incomes \\
\hline & Changed fertilizer plans & $\begin{array}{l}\text { Afforestation and } \\
\text { reforestation }\end{array}$ \\
\hline & $\begin{array}{l}\text { Agroforestry systems and } \\
\text { shade trees }\end{array}$ & Solar driers (processing) \\
\hline & Cover crops & \\
\hline \multirow{4}{*}{$\begin{array}{l}\text { Pham et al. } \\
\text { (2019), } \\
\text { coffee specific, } \\
\text { adaptation }\end{array}$} & $\begin{array}{l}\text { Irrigation and efficient water- } \\
\text { use }\end{array}$ & Crop insurance \\
\hline & New cultivars & Off-farm livelihoods \\
\hline & Diversification & Arabica replacement \\
\hline & Relocation & Agroforestry \\
\hline \multirow{4}{*}{$\begin{array}{l}\text { Rahn et al. } \\
\text { (2014), } \\
\text { coffee specific } \\
1, \\
\text { a \& m }\end{array}$} & Forest on degraded areas & Promote adequate fertilization \\
\hline & $\begin{array}{l}\text { Coffee agroforestry on } \\
\text { degraded areas }\end{array}$ & Avoid deforestation \\
\hline & Tree plantings as windbreaks & $\begin{array}{l}\text { Biodigesters and wastewater } \\
\text { treatment (processing) }\end{array}$ \\
\hline & $\begin{array}{l}\text { Improved soil conservation } \\
\text { practices }\end{array}$ & \\
\hline
\end{tabular}




\begin{tabular}{|c|c|c|}
\hline \multirow[t]{2}{*}{$\begin{array}{l}\text { Source, } \\
\text { topic of source } \\
\text { types of } \\
\text { practices }\end{array}$} & \multicolumn{2}{|c|}{$\begin{array}{l}\text { Practices named } \\
{ }^{+} \text {CSA refers to climate-smart agriculture } \\
* \text { a \& } m \text { refers to combined adaptation and mitigation } \\
{ }_{1} \text { special focus on Nicaragua } \\
{ }_{2}^{2} \text { special focus on Honduras / Central America }\end{array}$} \\
\hline & \multicolumn{2}{|l|}{ Practices named: } \\
\hline \multirow{10}{*}{$\begin{array}{l}\text { CIAT (2017) } \\
\text { coffee specific }{ }^{2}, \\
\text { CSA }\end{array}$} & Cover crop soil management & Drip irrigation \\
\hline & Use of permanent shade & Application of biochar \\
\hline & $\begin{array}{l}\text { Selection of rust-resistant } \\
\text { varieties }\end{array}$ & Lime sulfur against coffee rust \\
\hline & Low cover crops & Gypsum application to soil \\
\hline & $\begin{array}{l}\text { Soil moisture retention/mulch } \\
\text { coverage }\end{array}$ & $\begin{array}{l}\text { Swales for improved water } \\
\text { management }\end{array}$ \\
\hline & Temporary shade & $\begin{array}{l}\text { Grafting Arabica cion onto } \\
\text { Robusta rootstock }\end{array}$ \\
\hline & Live fences & $\begin{array}{l}\text { Use of deeper bags for } \\
\text { seedlings }\end{array}$ \\
\hline & Windbreak curtains & $\begin{array}{l}\text { Use of mycorrhiza in seedlings } \\
\text { and nurseries }\end{array}$ \\
\hline & Rainwater harvesting & Use of trichoderma \\
\hline & Water retention polymers & \\
\hline \multirow{4}{*}{$\begin{array}{l}\text { As a reference: } \\
\text { functional } \\
\text { groupings } \\
\text { defined in } \\
\text { chapter II.2.1: }\end{array}$} & Soil characteristics & Nutrient management \\
\hline & Water management & $\begin{array}{l}\text { Natural habitats and structural } \\
\text { elements }\end{array}$ \\
\hline & Crop and genetic diversity & System functioning \\
\hline & Climate buffer \& adjustment & \\
\hline
\end{tabular}




\section{B. References}

Avelino, J., Romero-Gurdián, A., Cruz-Cuellar, H. F., \& Declerck, F. A. J. (2012). Landscape context and scale differentially impact coffee leaf rust, coffee berry borer, and coffee root-knot nematodes. Ecological Applications, 22(2), 584-596.

Bastian, O., Grunewald, K., Syrbe, R.-U., Walz, U., \& Wende, W. (2014). Landscape services: the concept and its practical relevance. Landscape Ecology, 29(9), 1463-1479.

Biesbroek, G. R., Swart, R. J., \& van der Knaap, W. G.M. (2009). The mitigation-adaptation dichotomy and the role of spatial planning. Habitat International, 33(3), 230-237.

Bogdanski, A. (2012). Integrated food-energy systems for climate-smart agriculture. Agriculture \& Food Security, 1(1), 3.

Brandt, P., Kvakić, M., Butterbach-Bahl, K., \& Rufino, M. C. (2017). How to target climate-smart agriculture? Concept and application of the consensus-driven decision support framework "targetCSA". Agricultural Systems, 151, 234-245.

Bryan, E., Ringler, C., Okoba, B., Roncoli, C., Silvestri, S., \& Herrero, M. (2013). Adapting agriculture to climate change in Kenya: household strategies and determinants. Journal of environmental management, 114, 26-35.

Bunn, C., Läderach, P., Rivera, O. O., \& Kirschke, D. (2014). A bitter cup: Climate Change profile of global Arabica and Robusta production: Conference contribution. Montpellier, France: 22nd ASIC Conference. Retrieved February 24, 2020, from https://www.slideshare.net/ChristianBunn/a5-bunn-asic2014ccimpacts.

Bunn, C., Läderach, P., Ovalle Rivera, O., \& Kirschke, D. (2015a). A bitter cup: climate change profile of global production of Arabica and Robusta coffee. Climatic Change, 129(1-2), 89101.

Bunn, C., Läderach, P., Pérez Jimenez, J. G., Montagnon, C., \& Schilling, T. (2015b). Multiclass Classification of Agro-Ecological Zones for Arabica Coffee: An Improved Understanding of the Impacts of Climate Change. PloS one, 10(10).

c\&c (2015). Climate Change Adaptation in Coffee Production: A step-by-step guide to supporting coffee farmers in adapting to climate change. Initiative for coffee \& climate (c\&c). Retrieved November 02, 2019, from https://toolbox.coffeeandclimate.org/wpcontent/uploads/2012/10/cc-step-by-step-guide-for-climate-change-adaptation-in-coffeeproduction.pdf.

Castellanos, E. J., Tucker, C., Eakin, H., Morales, H., Barrera, J. F., \& Díaz, R. (2013). Assessing the adaptation strategies of farmers facing multiple stressors: Lessons from the Coffee and Global Changes project in Mesoamerica. Environmental Science \& Policy, 26, 19-28.

CFA (2020). Cool Farm Tool - An online greenhouse gas, water, and biodiversity calculator. Retrieved February 05, 2020, from Cool Farm Alliance (CFA): https://coolfarmtool.org/.

CGIAR (2018). Financial service supply with potential for supporting climate-smart agriculture (CCAFS Working Paper No. 208). Consultative Group for International Agricultural Research. Retrieved February 18, 2020, from https://cgspace.cgiar.org/bitstream/handle/10568/92990/Financial_service_Supply_with_Po tential_for_Supporting_CSA.pdf?sequence=5\&isAllowed=y.

Chemura, A., Kutywayo, D., Chidoko, P., \& Mahoya, C. (2016). Bioclimatic modelling of current and projected climatic suitability of coffee (Coffea arabica) production in Zimbabwe. Regional Environmental Change, 16(2), 473-485.

CIAT (2017). Climate Smart coffee in Honduras. Cali, Colombia: International Center for Tropical Agriculture (CIAT), United States Agency for International Development (USAID). Retrieved November 02, 2019, from https://hdl.handle.net/10568/97530.

Clark, W. (2010). Principles of Landscape Ecology. Nature Education Knowledge, 3(10), 34. Retrieved February 27, 2020, from 
https://www.nature.com/scitable/knowledge/library/principles-of-landscape-ecology13260702/.

Descroix, F., \& Snoeck, J. (2009). Environmental factors suitable for coffee cultivation. In J. N. Wintgens (Ed.), Coffee: Growing, processing, sustainable production. A guidebook for growers, processors, traders, and researchers (2nd ed., pp. 168-181). Weinheim: WILEY-VCH.

Díaz, S., Pascual, U., Stenseke, M., Martín-López, B., Watson, R. T., Molnár, Z., et al. (2018). Assessing nature's contributions to people. Science (New York, N.Y.), 359(6373), 270-272.

Eakin, H., Tucker, C. M., Castellanos, E., Diaz-Porras, R., Barrera, J. F., \& Morales, H. (2014). Adaptation in a multi-stressor environment: perceptions and responses to climatic and economic risks by coffee growers in Mesoamerica. Environment, Development and Sustainability, 16(1), 123-139.

EcoAgriculture Partners (2013). Defining Integrated Landscape Management for Policy Makers (Ecoagriculture Policy Focus No. 10). Washington DC, USA: EcoAgriculture Partners. Retrieved December 08, 2019, from https://ecoagriculture.org/wpcontent/uploads/2015/08/DefiningILMforPolicyMakers.pdf.

Ellison, D., Morris, C. E., Locatelli, B., Sheil, D., Cohen, J., Murdiyarso, D., et al. (2017). Trees, forests and water: Cool insights for a hot world. Global Environmental Change, 43, 51-61.

Enveritas (2018). How many coffee farmers are there? Global coffee farm study. cited in Sachs et al. 2019.

Escobar-Ramírez, S., Grass, I., Armbrecht, I., \& Tscharntke, T. (2019). Biological control of the coffee berry borer: Main natural enemies, control success, and landscape influence. Biological Control, 136, 103992.

Fagerholm, N., Käyhkö, N., Ndumbaro, F., \& Khamis, M. (2012). Community stakeholders' knowledge in landscape assessments - Mapping indicators for landscape services. Ecological Indicators, 18, 421-433. Retrieved February 05, 2020, from https://landscapevalues.org/publications/Fagerholm_services.pdf.

Fairtrade Foundation (2018). Carbon credits. Retrieved February 05, 2020, from https://info.fairtrade.net/product/carbon-credits.

Fairtrade Foundation (2020). Coffee farmers. Retrieved January 18, 2020, from http://www.fairtrade.org.uk/Farmers-and-Workers/Coffee.

FAO (2010a). "Climate-smart" agriculture: Policies, practices and financing for food security, adaptation and mitigation. Rome, Italy. Retrieved January 20, 2020, from http://www.fao.org/3/i1881e/i1881e00.pdf.

FAO (2010b). Carbon Finance Mechanisms for Smallholders. Rome, Italy: Food and Agriculture Organization of the United Nations (FAO). Retrieved February 05, 2020, from http://www.globalbioenergy.org/uploads/media/1002_FAO_-

_Carbon_finance_possibilities_for_agriculture_forestry_and_other_land_use_projects_in_a _smallholder_context.pdf.

FAO (2010c). Corporate strategy on capacity development (Programme Commitee cover notes No. 104). Rome: Food and Agriculture Organization of the United Nations (FAO). Retrieved February 27, 2020, from http://www.fao.org/fileadmin/user_upload/capacity_building/KM_Strategy.pdf.

FAO (2011). FAO Knowledge Strategy. Food and Agriculture Organization of the United Nations (FAO). Retrieved February 27, 2020, from http://www.fao.org/fileadmin/user_upload/capacity_building/KM_Strategy.pdf.

FAO (2013). Climate smart agriculture sourcebook. Rome: Food and Agriculture Organization of the United Nations (FAO). Retrieved November 10, 2019, from http://www.fao.org/climatesmart-agriculture-sourcebook/en/.

Fischer, J., Lindenmayer, D. B., \& Manning, A. D. (2006). Biodiversity, ecosystem function, and resilience: ten guiding principles for commodity production landscapes. Frontiers in Ecology 
and the Environment, 4(2), 80-86, from

http://www.fao.org/fileadmin/user_upload/newsroom/docs/Summary_Strategy_PR_E.pdf.

Foley, J. A., Ramankutty, N., Brauman, K. A., Cassidy, E. S., Gerber, J. S., Johnston, M., et al.

(2011). Solutions for a cultivated planet. Nature, 478(7369), 337-342.

Freeman, O. E. (2015). Characterising multifunctionality in climate-smart landscapes. In P. A. Minang, van Noordwijk, M., Freeman, O. E., C. Mbow, J. de Leeuw, \& D. Catacutan (Eds.), Climate-smart landscapes. Multifunctionality in practice (pp. 37-50). Nairobi, Kenya: World Agroforestry Centre (ICRAF).

GCP (2015). The Little Sustainable Landscapes Book. Global Canopy Programme (GCP), EcoAgriculture Partners, The Sustainable Trade Initiative, The Nature Conservancy, World Wide Fund for Nature. Retrieved January 31, 2020, from http://www.globalcanopy.org/sites/default/files/documents/resources/GCP_LSLB_English.pd f.

Ghazoul, J., Garcia, C., \& Kushalappa, C. G. (2009). Landscape labelling: A concept for nextgeneration payment for ecosystem service schemes. Forest Ecology and Management, 258(9), 1889-1895.

Gold Standard (2014). Leading businesses join Fairtrade and Gold Standard in the fight against climate change. Retrieved February 05, 2020, from The Gold Standard:

https://www.goldstandard.org/blog-item/leading-businesses-join-fairtrade-and-goldstandard-fight-against-climate-change.

Goldman, R. L., Thompson, B. H., \& Daily, G. C. (2007). Institutional incentives for managing the landscape: Inducing cooperation for the production of ecosystem services. Ecological Economics, 64(2), 333-343.

Grabs, J., \& Ponte, S. (2019). The evolution of power in the global coffee value chain and production network. Journal of Economic Geography, 19(4), 803-828.

Hart, A. K., Milder, J. C., Estrada-Carmona, N., DeClerck, F., Harvey, C. A., \& Doble, P. (2015). Integrated landscape initiatives in practice: assessing experiences from 191 landscapes in Africa and Latin America. In P. A. Minang, van Noordwijk, M., Freeman, O. E., C. Mbow, J. de Leeuw, \& D. Catacutan (Eds.), Climate-smart landscapes. Multifunctionality in practice (pp. 89-102). Nairobi, Kenya: World Agroforestry Centre (ICRAF).

Harvey, C. A., Chacón, M., Donatti, C. I., Garen, E., Hannah, L., Andrade, A., et al. (2014). ClimateSmart Landscapes: Opportunities and Challenges for Integrating Adaptation and Mitigation in Tropical Agriculture. Conservation Letters, 7(2), 77-90.

Harvey, C. A., Saborio-Rodríguez, M., Martinez-Rodríguez, M. R., Viguera, B., Chain-Guadarrama, A., Vignola, R., \& Alpizar, F. (2018). Climate change impacts and adaptation among smallholder farmers in Central America. Agriculture \& Food Security, 7(1), 17.

Hivos (2018). Coffee barometer 2018. Hivos, Conservation International, COSA, Oxfam Wereldwinkels, Solidaridad. Retrieved January 18, 2020, from https://www.hivos.org/assets/2018/06/Coffee-Barometer-2018.pdf.

Hölting, L., Beckmann, M., Volk, M., \& Cord, A. F. (2019). Multifunctionality assessments - More than assessing multiple ecosystem functions and services? A quantitative literature review. Ecological Indicators, 103, 226-235.

IITA (2019a). Climate smart investment pathways. International Institute of Tropical Agriculture (IITA). Retrieved February 04, 2020, from https://cgspace.cgiar.org/bitstream/handle/10568/100129/Final_Brief_StepwiseApproach_2 1022019\%20(003).pdf.

IITA (2019b). The farmer segementation tool. International Institute of Tropical Agriculture (IITA). Retrieved February 04, 2020, from https://cgspace.cgiar.org/bitstream/handle/10568/100128/http://Final_Brief_FarmerSegme ntation_20190221.pdf. 
IPCC (2015). AR 5 Synthesis Report - Climate Change 2014: Contribution of Working Groups I, II and III to the Fifth Assessment Report of the Intergovernmental Panel on Climate Change. Geneva, Switzerland: IPCC.

IPCC (2019). Climate Change and Land: IPCC Special Report on Climate Change, Desertification, Land Degradation, Sustainable Land Management, Food Security, and Greenhouse gas fluxes in Terrestrial Ecosystems. Intergovernmental Panel on Climate Change (IPCC). Retrieved January 21, 2020, from https://www.ipcc.ch/srccl/.

IPCC WG II (2014). Chapter 7 - Food Security and Food Production Systems. In Barros, V.R., C.B. Field, D.J. Dokken, M.D. Mastrandrea, K.J. Mach, T.E. Bilir, M. Chatterjee, K.L. Ebi, Y.O. Estrada, R.C. Genova, B. Girma, E.S. Kissel, A.N. Levy, S. MacCracken, P.R. Mastrandrea, and L.L.White (Ed.), Climate Change 2014: Impacts, Adaptation, and Vulnerability. Part B Regional Aspects. Contribution of Working Group IV to the Fifth Assessment Report of the Intergovernmental Panel on Climate Change (pp. 485-533). Cambridge, United Kingdom and New York, NY, USA: Cambridge University Press.

IPCC WG III (2014). Chapter 1 - Agriculture, Forestry and Other Land Use (AFOLU). In E. Edenhofer, R. Pichs-Madruga, \& Y. Sokona (Eds.), Climate Change 2014: Mitigation of Climate Change. Contribution of Working Group III to the Fifth Assessment Report of the Intergovernmental Panel on Climate Change (811-922). Cambridge, United Kingdom and New York, USA: Cambridge University Press.

ITC (2010). Climate Change and the Coffee Industry. In International Trade Centre (ITC) (Ed.), International Trade Forum Magazine. The Quarterly Magazine of the International Trade Centre .

Jaramillo, J., Muchugu, E., Vega, F. E., Davis, A., Borgemeister, C., \& Chabi-Olaye, A. (2011). Some like it hot: the influence and implications of climate change on coffee berry borer (Hypothenemus hampei) and coffee production in East Africa. PloS one, 6(9), e24528.

Jayakumar, M., Rajavel, M., Surendran, U., Gopinath, G., \& Ramamoorthy, K. (2017). Impact of climate variability on coffee yield in India-with a micro-level case study using long-term coffee yield data of humid tropical Kerala. Climatic Change, 145(3-4), 335-349.

Jha, S., Bacon, C. M., Philpott, S. M., Ernesto Méndez, V., Läderach, P., \& Rice, R. A. (2014). Shade Coffee: Update on a Disappearing Refuge for Biodiversity. BioScience, 64(5), 416-428.

Jha, S., Bacon, C. M., Philpott, S. M., Rice, R. A., Méndez, V. E., \& Läderach, P. (2011). A Review of Ecosystem Services, Farmer Livelihoods, and Value Chains in Shade Coffee Agroecosystems. In W. B. Campbell \& S. Lopez Ortiz (Eds.), Issues in Agroecology - Present Status and Future Prospectus: Vol. 1. Integrating Agriculture, Conservation and Ecotourism: Examples from the Field (pp. 141-208). Dordrecht: Springer Science+Business Media B.V.

Jiri, O., Mafongoya, P., \& Chivenge, P. (2015). Smallholder Farmer Perceptions on Climate Change and Variability: A Predisposition for their Subsequent Adaptation Strategies. Journal of Earth Science \& Climatic Change, 06(05).

Khatri-Chhetri, A., Aggarwal, P. K., Joshi, P. K., \& Vyas, S. (2017). Farmers' prioritization of climate-smart agriculture (CSA) technologies. Agricultural Systems, 151, 184-191.

Kilian, B., Rivera, L., Soto, M., \& Navichoc, D. (2013). Carbon Footprint across the Coffee Supply Chain: The Case of Costa Rican Coffee. Journal of Agricultural Science and Technology, 3(3), 151-170.

Krishnan, S. (2017). Sustainable Coffee Production. Retrieved February 05, 2020, from Oxford Research Encyclopedia of Environmental Science: https://oxfordre.com/environmentalscience/view/10.1093/acrefore/9780199389414.001.00.

Läderach, P., Lundy, M., Jarvis, A., Ramirez, J., Portilla, E. P., Schepp, K., \& Eitzinger, A. (2011). Predicted Impact of Climate Change on Coffee Supply Chains. In W. L. Filho (Ed.), Climate Change Management. The Economic, social and political elements of climate change (pp. 703-723). Berlin: Springer. 
Läderach, P., Ramirez-Villegas, J., Navarro-Racines, C., Zelaya, C., Martinez-Valle, A., \& Jarvis, A. (2017). Climate change adaptation of coffee production in space and time. Climatic Change, 141(1), 47-62. Retrieved November 02, 2019, from https://link.springer.com/content/pdf/10.1007\%2Fs10584-016-1788-9.pdf.

Lambin, E. F., Gibbs, H. K., Heilmayr, R., Carlson, K. M., Fleck, L. C., Garrett, R. D., et al. (2018). The role of supply-chain initiatives in reducing deforestation. Nature Climate Change, 8(2), 109-116.

Locatelli, B., Pavageau, C., Pramova, E., \& Di Gregorio, M. (2015). Integrating climate change mitigation and adaptation in agriculture and forestry: opportunities and trade-offs. Wiley Interdisciplinary Reviews: Climate Change, 6(6), 585-598.

Lovell, S. T., \& Johnston, D. M. (2009). Creating multifunctional landscapes: how can the field of ecology inform the design of the landscape? Frontiers in Ecology and the Environment, 7(4), 212-220.

McCarthy, N., Lipper, L., Branca, G. (2011). Climate Smart Agriculture: Smallholder Adoption and Implications for Climate Change Adaptation and Mitigation (Mitigation of Climate Change in Agriculture Series No. 4). Food and Agriculture Organization of the United Nations (FAO). Retrieved January 25, 2020, from http://www.fao.org/3/i2575e/i2575e00.pdf.

MEA (2003). Ecosystems and human well-being - A framework for assessment. Washington, DC: Island Press.

MEA (2005). Ecosystems and human well-being: Synthesis. Washington DC: Island Press.

Minang, P. A., van Noordwijk, M., Freeman, O. E., Duguma, C. M., Leeuw, J. de, \& Catacutan, D. (2015). Introduction and basic propositions. In P. A. Minang, van Noordwijk, M., Freeman, O. E., C. Mbow, J. de Leeuw, \& D. Catacutan (Eds.), Climate-smart landscapes. Multifunctionality in practice (pp. 3-18). Nairobi, Kenya: World Agroforestry Centre (ICRAF).

Moguel, P., \& Toledo, V. M. (1999). Biodiversity Conservation in Traditional Coffee Systems of Mexico. Conservation Biology, 13(1), 11-21.

Morton, J. F. (2007). The impact of climate change on smallholder and subsistence agriculture. Proceedings of the national academy of sciences, 104(50), 19680-19685.

Mosedale, J. R., Abernethy, K. E., Smart, R. E., Wilson, R. J., \& Maclean, I. M. D. (2016). Climate change impacts and adaptive strategies: lessons from the grapevine. Global change biology, 22(11), 3814-3828.

Muller, R., Berry, D., Avelino, J., \& Bieysse, D. (2009). Coffee Diseases. In J. N. Wintgens (Ed.), Coffee: Growing, processing, sustainable production. A guidebook for growers, processors, traders, and researchers (2nd ed., pp. 495-549). Weinheim: WILEY-VCH.

NAMA Café (2020). Inicio. Retrieved February 18, 2020, from Nationally Appropiate Mitigation Actions Café de Costa Rica (NAMA Café): https://www.namacafe.org/.

Noponen, M. R., Edwards-Jones, G., Haggar, J. P., Soto, G., Attarzadeh, N., \& Healey, J. R. (2012). Greenhouse gas emissions in coffee grown with differing input levels under conventional and organic management. Agriculture, Ecosystems \& Environment, 151, 6-15.

O'Farrell, P. J., \& Anderson, P. M. (2010). Sustainable multifunctional landscapes: a review to implementation. Current Opinion in Environmental Sustainability, 2(1-2), 59-65.

Öborn, I., Kuyah, S., Jonsson, M., Dahlin, A. S., Mwangi, H., \& Leeuw, J. de (2015). Landscapelevel constraints and opportunities for sustainable intensification in smallholder systems in the tropics. In P. A. Minang, van Noordwijk, M., Freeman, O. E., C. Mbow, J. de Leeuw, \& D. Catacutan (Eds.), Climate-smart landscapes. Multifunctionality in practice (pp. 163-178). Nairobi, Kenya: World Agroforestry Centre (ICRAF).

OECD (2000). Agricultural Policies in OECD Countries 2000: Monitoring and Evaluation (Agriculture and Food). Washington. Retrieved December 19, 2019, from https://www.oecdilibrary.org/docserver/agr_oecd-2000en.pdf?expires $=1579535511 \& i d=i d \& a c c n a m e=0 i d 009539 \&$ checksum $=62 F B D 4 C 720 A 8 B 2 D 63$ D31B622293DA5C3. 
Opdam, P., Luque, S., Nassauer, J., Verburg, P. H., \& Wu, J. (2018). How can landscape ecology contribute to sustainability science? Landscape Ecology, 33(1), 1-7.

Pascual, U., Balvanera, P., Díaz, S., Pataki, G., Roth, E., Stenseke, M., et al. (2017). Valuing nature's contributions to people: the IPBES approach. Current Opinion in Environmental Sustainability, 26-27, 7-16.

Perfecto, I., Vandermeer, J., Mas, A., \& Pinto, L. S. (2005). Biodiversity, yield, and shade coffee certification. Ecological Economics, 54(4), 435-446.

Pham, Y., Reardon-Smith, K., Mushtaq, S., \& Cockfield, G. (2019). The impact of climate change and variability on coffee production: a systematic review. Climatic Change, 7(4).

Pimm, S. L., Jenkins, C. N., Abell, R., Brooks, T. M., Gittleman, J. L., Joppa, L. N., et al. (2014). The biodiversity of species and their rates of extinction, distribution, and protection. Science (New York, N.Y.), 344(6187), 1246752.

Ponte, S. (2002). The 'Latte Revolution'? Regulation, Markets and Consumption in the Global Coffee Chain. World Development, 30(7), 1099-1122.

Rahn, E., Läderach, P., Baca, M., Cressy, C., Schroth, G., Malin, D., et al. (2014). Climate change adaptation, mitigation and livelihood benefits in coffee production: where are the synergies? Mitigation and Adaptation Strategies for Global Change, 19(8), 1119-1137.

Reed, J., van Vianen, J., Deakin, E. L., Barlow, J., \& Sunderland, T. (2016). Integrated landscape approaches to managing social and environmental issues in the tropics: learning from the past to guide the future. Global change biology, 22(7), 2540-2554.

Rodriguez, B., \& Vasquez, M. (2009). Economic Aspects of Coffee Production. In J. N. Wintgens (Ed.), Coffee: Growing, processing, sustainable production. A guidebook for growers, processors, traders, and researchers (2nd ed., pp. 831-842). Weinheim: WILEY-VCH.

rootcapital (2020). About us. Retrieved February 18, 2020, from rootcapital: https://rootcapital.org/about-us/.

Rosenzweig, C., \& Tubiello, F. N. (2007). Adaptation and mitigation strategies in agriculture: an analysis of potential synergies. Mitigation and Adaptation Strategies for Global Change, 12(5), 855-873, from https://link.springer.com/content/pdf/10.1007/s11027-007-91038.pdf.

Sachs, J., Cordes, K., Rising, J., Toledano, P., \& Maennling, N. (2019). Ensuring Economic Viability an Sustainability of Coffee Production. Columbia Center on Sustainable Investment. Retrieved December 14, 2019, from http://ccsi.columbia.edu/files/2018/04/Ensuring-EconomicViability-and-Sustainability-of-Coffee-Production-CCSI-2019.pdf.

Salomone, R. (2003). Life Cycle Assessment applied to coffee production. Food, Agriculture \& Environment, 1(2), 295-300.

Sayer, J., Sunderland, T., Ghazoul, J., Pfund, J.-L., Sheil, D., Meijaard, E., et al. (2013). Ten principles for a landscape approach to reconciling agriculture, conservation, and other competing land uses. Proceedings of the National Academy of Sciences of the United States of America, 110(21), 8349-8356.

Scherr, S., Shames, S., \& Friedman, R. (2012). From climate-smart agriculture to climate-smart landscapes. Agriculture \& Food Security, 1(1).

Schnabel, F., Melo Virginio Filho, E. de, Xu, S., Fisk, I. D., Roupsard, O., \& Haggar, J. (2018). Shade trees: a determinant to the relative success of organic versus conventional coffee production. Agroforestry Systems, 92(6), 1535-1549.

Silva, C. A. (2017). The Coffee Cultural Landscape of Colombia. Journal of World Heritage Studies. (Special Issue), 44-50. Retrieved February 01, 2020, from http://doi.org/10.15068/00148448.

Soto-Pinto, L., Perfecto, I., Castillo-Hernandez, J., \& Caballero-Nieto, J. (2000). Shade effect on coffee production at the northern Tzeltal zone of the state of Chiapas, Mexico. Agriculture, Ecosystems \& Environment, 80(1-2), 61-69. 
Stafford Smith, M., Horrocks, L., Harvey, A., \& Hamilton, C. (2011). Rethinking adaptation for a $4^{\circ} \mathrm{C}$ world. Philosophical transactions. Series A, Mathematical, physical, and engineering sciences, 369(1934), 196-216.

Steffen, W., Richardson, K., Rockström, J., Cornell, S. E., Fetzer, I., Bennett, E. M., et al. (2015). Sustainability. Planetary boundaries: guiding human development on a changing planet. Science (New York, N.Y.), 347(6223), 1259855.

Stern, N. H. (2006). The economics of climate change: The Stern review. Cambridge, United Kingdom: Great Britain. Retrieved February 04, 2020, from http://www.loc.gov/catdir/enhancements/fy0803/2007275608-b.html.

The Sustainable Food Lab \& CIAT (2019). CSA Guide - Take action. Retrieved February 21, 2020, from The Sustainable Food Lab, International Center for Tropical Agriculture (CIAT): https://climatesmartcoffee.csa.guide/take-action/know-your-risk.

Suyanto, S., Ekadinata, A., Mulia, R., Johana, F., \& Widayati, A. (2015). The opportunity costs of emission reduction: a methodology and application to support land use planning for low emission development. In P. A. Minang, van Noordwijk, M., Freeman, O. E., C. Mbow, J. de Leeuw, \& D. Catacutan (Eds.), Climate-smart landscapes. Multifunctionality in practice (pp. 227-241). Nairobi, Kenya: World Agroforestry Centre (ICRAF).

$\mathrm{TCI}$ (2016). A brewing storm: the climate change risks to coffee. The Climate Institute (TCI). Retrieved January 18, 2020, from http://www.climateinstitute.org.au/verve/_resources/TCI_A_Brewing_Storm_FINAL_WEB27 0916.pdf.

TEEB (2020). TEEBAgriFood Exploratory Study - Palm Oil. Retrieved February 21, 2020, from The Economics of Ecosystems \& Biodiversity (TEEB): http://www.teebweb.org/agrifoodarchive/palm-oil/.

Termorshuizen, J. W., \& Opdam, P. (2009). Landscape services as a bridge between landscape ecology and sustainable development. Landscape Ecology, 24(8), 1037-1052.

Torquebiau, E. (2015). Whither landscapes? Compiling requirements of the landscape approach. In P. A. Minang, van Noordwijk, M., Freeman, O. E., C. Mbow, J. de Leeuw, \& D. Catacutan (Eds.), Climate-smart landscapes. Multifunctionality in practice (pp. 21-36). Nairobi, Kenya: World Agroforestry Centre (ICRAF).

TRUCOST (2016). Improving business decision making: valuing the hidden costs of production in the palm oil sector. Trucost, True Price, The Economics of Ecosystems and Biodiversity (TEEB), from http://img.teebweb.org/wpcontent/uploads/2016/12/TEEBAgriFood_PalmOil_Report.pdf.

Tscharntke, T., Clough, Y., Bhagwat, S. A., Buchori, D., Faust, H., Hertel, D., et al. (2011). Multifunctional shade-tree management in tropical agroforestry landscapes - a review. Journal of Applied Ecology, 48(3), 619-629.

Tscharntke, T., Klein, A. M., Kruess, A., Steffan-Dewenter, I., \& Thies, C. (2005). Landscape perspectives on agricultural intensification and biodiversity and ecosystem service management. Ecology Letters, 8(8), 857-874.

Tscharntke, T., Milder, J. C., Schroth, G., Clough, Y., DeClerck, F., Waldron, A., et al. (2015). Conserving Biodiversity Through Certification of Tropical Agroforestry Crops at Local and Landscape Scales. Conservation Letters, 8(1), 14-23.

Tscharntke, T., Tylianakis, J. M., Rand, T. A., Didham, R. K., Fahrig, L., Batáry, P., et al. (2012). Landscape moderation of biodiversity patterns and processes - eight hypotheses. Biological reviews of the Cambridge Philosophical Society, 87(3), 661-685.

UNESCO (1993). Biosphere Reserve Information - Mexico: El Triunfo. Retrieved February 09, 2020, from United Nations Educational, Scientific and Cultural Organization (UNESCO): http://www.unesco.org/mabdb/br/brdir/directory/biores.asp?mode=all\&code=MEX+08.

UNESCO (2007). Biosphere Reserve Information - El Salvador: Apaneca-llamatepec. Retrieved February 09, 2020, from United Nations Educational, Scientific and Cultural Organization 
(UNESCO):

http://www.unesco.org/mabdb/br/brdir/directory/biores.asp?mode=all\&code=SLV+01.

UNESCO (2010). Biosphere Reserve Information - Ethiopia: Yayu Coffee Forest. Retrieved February 09, 2020, from United Nations Educational, Scientific and Cultural Organization (UNESCO):

http://www.unesco.org/new/fileadmin/MULTIMEDIA/HQ/SC/pdf/sc_mab_Ethiopia_Yayu_EN .pdf.

UNESCO (2020a). Coffee Cultural Landscape of Colombia - World Heritage List. Retrieved February 08, 2020, from United Nations Educational, Scientific and Cultural Organization (UNESCO): https://whc.unesco.org/en/list/1121.

UNESCO (2020b). MAB Programme. Retrieved February 05, 2020, from United Nations Educational, Scientific and Cultural Organization (UNESCO):

http://www.unesco.org/new/en/natural-sciences/environment/ecological-sciences/manand-biosphere-programme/.

USDA (2019). Coffee: World Markets and Trade. United States Department of Agriculture (USDA). Retrieved January 21, 2020, from https://apps.fas.usda.gov/psdonline/circulars/coffee.pdf.

UTZ (2020). UTZ Coffee Climate Care (C3) - UTZ. Retrieved February 21, 2020, from UTZ / Rainforest Alliance: https://utz.org/what-we-offer/sector-change/climate-change/coffeeclimate-care-c3/.

van Noordwijk, M., Leimona, B., Xing, M., Tanika, L., Namirembe, S., \& Suprayogo, D. (2015). Water-focused landscape management. In P. A. Minang, van Noordwijk, M., Freeman, O. E., C. Mbow, J. de Leeuw, \& D. Catacutan (Eds.), Climate-smart landscapes. Multifunctionality in practice (pp. 179-193). Nairobi, Kenya: World Agroforestry Centre (ICRAF).

van Rikxoort, H., Schroth, G., Läderach, P., \& Rodríguez-Sánchez, B. (2014). Carbon footprints and carbon stocks reveal climate-friendly coffee production. Agronomy for Sustainable Development, 34(4), 887-897.

Verburg, R., Rahn, E., Verweij, P., van Kuijk, M., \& Ghazoul, J. (2019). An innovation perspective to climate change adaptation in coffee systems. Environmental Science \& Policy, 97, 16-24.

Vermeulen, S. J., Challinor, A. J., Thornton, P. K., Campbell, B. M., Eriyagama, N., Vervoort, J. M., et al. (2013). Addressing uncertainty in adaptation planning for agriculture. Proceedings of the National Academy of Sciences of the United States of America, 110(21), 8357-8362.

Wallbott, L., Siciliano, G., \& Lederer, M. (2019). Beyond PES and REDD+: Costa Rica on the way to climate-smart landscape management? Ecology and Society, 24(1).

Waller, J. M., Bigger, M., \& Hillocks, R. J. (2007). Coffee pests, diseases and their management. $C A B$ books. Wallingford, UK, Cambridge, MA: CABI.

WCR (2020). Global Coffee Monitoring Program. Retrieved February 21, 2020, from World Coffee Research (WCR): https://worldcoffeeresearch.org/work/-farm-demonstration-trialnetwork/.

Williams-Guillén, K., \& Otterstrom, S. (2014). Market-Based Incentives for the Conservation of Ecosystem Services in Agricultural Landscapes: Examples from Coffee Cultivation in Latin America. In N. K. van Alfen (Ed.), Encyclopedia of Agriculture and Food Systems (pp. 172-185). Elsevier.

Winget, M., Lamb, N., \& Wheatley, K. (2017). Root Capital: Measuring the Effects of Impact Investing on Impoverished Rural Communities. Journal of Case Studies, 35(2), 88-113.

Wintgens, J., \& Descroix, F. (2009). Establishing a Coffee Plantation. In J. N. Wintgens (Ed.), Coffee: Growing, processing, sustainable production. A guidebook for growers, processors, traders, and researchers (2nd ed., pp. 182-249). Weinheim: WILEY-VCH.

Wintgens, J. N. (Ed.) (2009). Coffee: Growing, processing, sustainable production: A guidebook for growers, processors, traders, and researchers (2., updated ed.). Weinheim: WILEY-VCH. 
WIPO (2015). Making the Origin Count: The Colombian Experience. Retrieved February 05, 2020, from World Intellectual Property Organization (WIPO):

https://www.wipo.int/ipadvantage/en/details.jsp?id=2617.

World Bank (2011). Climate-smart agriculture: Increased productivity and food security, enhanced resilience and reduced emissions for sustainable development (English). Washington DC: World Bank. Retrieved November 02, 2019, from http://documents.worldbank.org/curated/en/501551468163165831/pdf/762380WPOClima0 OBox374367B00PUBLICO.pdf.

World Bank (2016). Agricultural land (\% of land area). Retrieved January 20, 2020, from The World Bank Group: https://data.worldbank.org/indicator/AG.LND.AGRI.ZS?end=2016\&start=1961\&view=chart. $\mathrm{Wu}$, J. (2013). Landscape sustainability science: ecosystem services and human well-being in changing landscapes. Landscape Ecology, 28(6), 999-1023.

Zhang, W., Ricketts, T. H., Kremen, C., Carney, K., \& Swinton, S. M. (2007). Ecosystem services and dis-services to agriculture. Ecological Economics, 64(2), 253-260. 


\section{Eidesstattliche Erklärung}

Ich versichere hiermit, dass ich die vorliegende Arbeit

\section{Shaping climate-smart coffee landscapes}

selbständig und ohne Benutzung anderer als der angegebenen Hilfsmittel angefertigt habe. Mir ist bewusst, dass die Arbeit mit Software zur Plagiatsprävention überprüft werden kann.

Göttingen, den

Paul Günter Schmidt 